CARLOS EDUARDO BEZERRA DE MOURA

O bombardeamento da superfície de titânio com íons de argônio influencia a resposta biológica de pré-osteoblastos 


\section{O bombardeamento da superfície de titânio com íons de argônio influencia a resposta biológica de pré-osteoblastos}

Tese apresentada ao Programa de PósGraduação em Anatomia dos Animais Domésticos e Silvestres da Faculdade de Medicina Veterinária e Zootecnia da Universidade de São Paulo, para a obtenção do título de Doutor em Ciências

Departamento:

Cirurgia

Área de Concentração:

Anatomia dos Animais Domésticos e Silvestres

Orientadora:

Prof ${ }^{\mathrm{a}}$. Dr ${ }^{\mathrm{a}}$. Paula de Carvalho Papa

São Paulo 
Autorizo a reprodução parcial ou total desta obra, para fins acadêmicos, desde que citada a fonte.

DADOS INTERNACIONAIS DE CATALOGAÇÃO-NA-PUBLICAÇÄO

(Biblioteca Virginie Buff D'Ápice da Faculdade de Medicina Veterinária e Zootecnia da Universidade de São Paulo)

Moura, Carlos Eduardo Bezerra de influencia a resposta biológica de pré-osteoblastos / Carlos Eduardo Bezerra de Moura. - São Paulo: C. E. B. Moura, 2007.

$105 \mathrm{f}$ : : il.

Tese (doutorado) - Universidade de São Paulo. Faculdade de Medicina Veterinária e Zootecnia. Departamento de Cirurgia, 2007.

Programa de Pós-Graduação: Anatomia dos Animais Domésticos e Silvestres.

Área de concentração: Anatomia dos Animais Domésticos e Silvestres.

Orientador: Profa. Dra. Paula de Carvalho Papa.

1. Implantes dentários. 2. Regeneração óssea. 3. Proliferação celular. I. Título. 


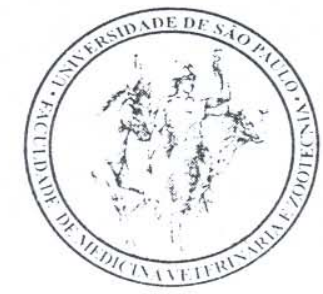

\section{UNIVERSIDADE DE SÃO PAULO \\ Faculdade de Medicina Veterinária e Zootecnia}

Comissão Bioética

\section{CERTIFICADO}

Certificamos que o Projeto intitulado "Influência da superfície de titânio sobre a adesão, diferenciação e proliferação de células pré-osteoblásticas e células tronco de cordão umbilical humano", protocolado sob o n991/2006, não utilizando animais, sob a responsabilidade da Profa. Dra. Paula de Carvalho Papa está de acordo com os princípios éticos de experimentação animal da Comissão de Bioética da Faculdade de Medicina Veterinária e Zootecnia da Universidade de São Paulo e foi aprovado em reunião de 18/10/06".

(We certify that the Research "Influence of titanium surface on differentiation and proliferation of pré-osteoblast and stem cells from human umbilical cord", protocol number 991/2006, under the responsibility of Prof. Dr. Paula de Carvalho Papa, agree with Ethical Principles in Animal Research adopted by Bioethic Commission of the School of Veterinary Medicine and Zootechny of University of São Paulo and was approved in the meeting of the day 10/18/2006).

São Paulo, 18 de outubro de 2006

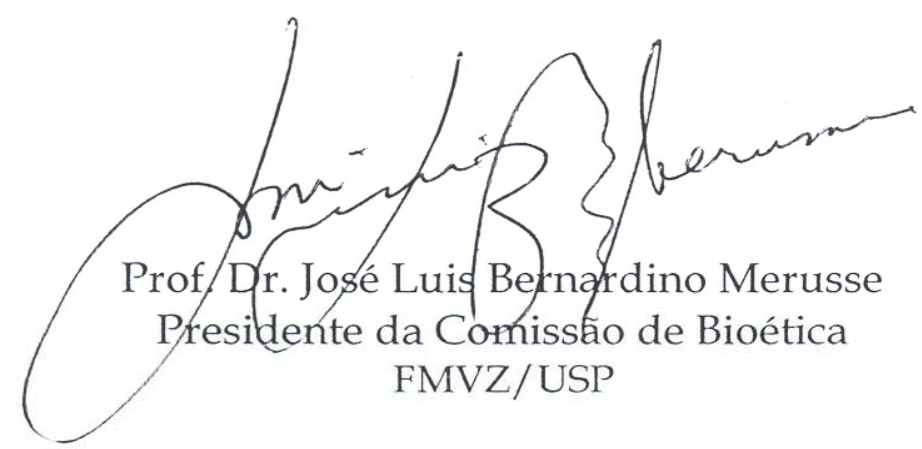


Nome: MOURA, Carlos Eduardo Bezerra

Título: O bombardeamento da superfície de titânio com íons de argônio influencia a resposta biológica de pré-osteoblastos

Tese apresentada ao Programa de PósGraduação em Anatomia dos Animais Domésticos e Silvestres da Faculdade de Medicina Veterinária e Zootecnia da Universidade de São Paulo, para a obtenção do título de Doutor em Ciências

Data:

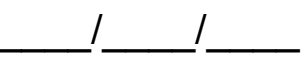

\section{Banca Examinadora}

Prof. Dr.

Julgamento:

Prof. Dr.

Julgamento:

Prof. Dr.

Julgamento:

Prof. Dr.

Julgamento:

Prof. Dr.

Julgamento:
Instituição:

Assinatura:

Instituição:

Assinatura:

Instituição:

Assinatura:

Instituição:

Assinatura:

Instituição:

Assinatura: 


\section{Deus,}

OTão kenho palavras pra agradecer tua bondade

Dia após dia me cercas com fidelidade

Tunca me deixes esquecer

Que kndo o que kenho

Juda o que son

(O) que vier a ser

$\mathcal{O}_{e m} d_{e} \mathcal{J}_{i} \Phi_{\text {enhor }}$

Dependa de $\mathcal{J}_{i}$

Preciso de $\mathcal{O}_{i}$

Sozinho, nada posso fazer.

Descanso em $\mathfrak{J}_{i}$

Espero em $\mathfrak{J}_{i}$

Sozinho, nada posso fazer.

Judo o que kenho

Judo o que sou

O que vier a ser

Oem de Ji Senhor.

(Composição: Q Qna Paula Oaladão) 
As mulheres de minha vida... Dizem "que atrás de um grande homem existe uma grande mulher". Eu digo atrás de um pequeno homem existem quatro

grandes mulheres: minha mãe, minha avó Auxiliadora, minha tia Anete e minha noiva

Maria Tereza. Amo muito vocês!

Á minha mãe Ana Maria Bezerra Neres,

Mãe querida, amada, sofrida... Ignora as discriminações da sociedade Em prol do seu amor e se preciso for

Da a sua própria vida

Esquece-se de si mesma Por desejar a vitória do filho E ao vibrar com as vitórias alcançadas Nem se lembra de seu próprio mérito

Mãe é como uma flor... É carinho, cuidado, proteção, Compreensão, doação, perdão... Mãe resume tudo o que é amor!

Mãe é a própria canção de amor, Tocada suavemente em nossos corações...

Agradeço a você mãe Todo o amor por minha vida!

(Star, 2004) 
A minha noiva Maria Tereza Marinho Miranda,

Não dá mais pra conter eu tenho que dizer

Pra todo mundo ouvir que você é a parte Que Deus me completou com carinho e ternura

E muito amor

Sempre quero te amar e compreender Sempre pedir pra Deus proteger você e eu Sempre fazer te feliz, é o meu querer Não sou perfeito, mas prometo Sempre te amar.

(Composição: Sergio Lopes)

\section{A Vovó Auxiliadora,}

Pessoa do Bem,

Melhor não tem,

É avó do coração,

Feita de emoção,

Você é como eu sonhei,

Por um instante ajoelhei,

E me perguntei,

Será que afinal,

Uma vez,

Eu sonho você e eu,

Tudo de uma vez.

Você é a estrela, a lua e o mar, A luz que me faz sonhar.

Realmente não há ninguém assim, Você é tudo para mim...

(Poesia de Natália Martinello Moreira) 
A minha orientadora Paula de Carvalho Papa,

"Ser Orientador é um desafio.

É acreditar na força das pessoas e nas suas capacidades.

É ser amigo que ajuda incondicionalmente,

Mas que critica construtivamente quando há erro.

É ouvir o silêncio de um olhar, o barulho de uma lágrima,

A alegria de um sorriso ou o calor de um abraço.

É perscrutar atitudes,

É ler nas entrelinhas,

Olhar e ver por além do que os olhos alcançam.

É construir e reconstruir;

Construir alicerces para a vida e reconstruir os caminhos perdidos."

Texto adaptado por minha do poema "Ser professor" de Fly. Escolhi esse texto, pois retrata muito bem o que você foi para mim todos esses anos de convivência e por esse motivo dedico em especial esse trabalho a você. 


\section{AGRADECIMENTOS}

Aos Professores Hugo Alexandre de Oliveira Rocha e Naisandra Bezerra da Silva pela contribuição essencial na execução deste trabalho, sem eles a realização deste sonho não seria possível, mas sou grato, acima de tudo pela amizade e companheirismo. Acredito muito nessa parceria!

A Bióloga Maria de Lourdes Freitas mais do que uma "enfermeira" me auxiliando no fluxo laminar, mostrou-se uma amiga inestimável.

Ao Prof. Clodomiro Alves Júnior, um pesquisador exemplar, o cabeça do nosso grupo multidisciplinar de biomateriais. Obrigado pela confiança depositada em mim para testar um dos materiais produzidos pelo grupo e acima de tudo por me permitir fazer parte do mesmo.

A Profa Silvia Regina Batistuzzo de Medeiros, outra referência em nosso grupo. Obrigado pela confiança e por ter aberto as portas dos Laboratórios de Biologia Molecular e Genética (LBMG) e de Mutagênese Ambiental (LAMA) da Universidade Federal do Rio Grande do Norte para realização dos testes de mutagênese e genotoxicidade.

A Profa Maria Angélica Miglino pela oportunidade que me concedeu de participar de um grupo expoente na pesquisa em morfologia nacional, mas acima de tudo obrigado pela confiança e pelo carinho.

Ao Prof. Geraldo Barroso Cavalcanti Júnior pela colaboração nas análises de citometria de Fluxo e tempo dispensados a execução desta pesquisa.

Ao Prof. Dimas Tadeu Covas pelo estágio concedido no Laboratório de Cultura de Células do Hemocentro da Faculdade de Medicina de Ribeirão Preto da Universidade de São Paulo e a Bióloga Maristela Delgado pela orientação durante o estágio.

A Profa. Carmem Veríssimo do Departamento de Bioquímica, da Universidade de Campinas (UNICAMP) pela doação das células pré-oesteoblásticas. 
Ao Prof José Alzamir Pereira da Costa pela colaboração nas análises de Microscopia de Força Atômica

A Profa Tatiana Carlesso dos Santos pela colaboração na Microscopia Eletrônica de Varredura.

A Juliana Carvalho Sá e Manuela Bessa Magalhães Alves pela colaboração na produção e tratamento dos discos de titânio. Em nome das quais agradeço a todos que formam a equipe do Laboratório de Processamento de Materiais por Plasma da Universidade Federal do Rio Grande do Norte.

A Joana Cristina Medeiros Tavares, Jefferson da Silva Barbosa e Thiago de Melo Cabral pela colaboração nos testes de mutagênese e genotoxicidade. Em nome dos quais agradeço a todos que formam a equipe dos Laboratórios de Biologia Molecular e Genética (LBMG) e de Mutagênese Ambiental (LAMA).

A todos que formam a equipe do Laboratório de Biopolímeros (Biopol) da Universidade Federal do Rio Grande do Norte pela acolhida, carinho e respeito dedicados a mim.

Ao Prof. Osiel Benedito de Almeida pelo grande apoio quando esteve na chefia do Departamento de Morfologia da Universidade Federal do Rio Grande do Norte.

Aos Professores da Pós graduação Irvênia Luiza Santis Prada, Pedro Primo Bombonato, José Roberto Kfoury Júnior, Francisco Javier Hernadez-Blasquez, em nome dos quais saúdo todos os demais que contribuirão como minha formação profissional.

Aos amigos de Pós-graduação do Laboratório para estudos morfofuncionais e endocrinologia (LEME): Laura Artoni Pacheco, Danila Barreiro Campos, Liza Margareth M. C. Souza, Alex Sander Dias Machado, José Eduardo Barbosa Marques Junior, Carolina do Prado, Mariana Nunes La Paz, Vanessa Coutinho do Amaral e Vanessa Vemura pelos momentos agradáveis de companheirismo e amizade.

Aos amigos da Pós-graduação Naianne Kelly Clebis, Karina Martinez Gagliardo, Lucas Alécio Gomes, Gisele Saviani, Renata de Britto Mari em nome dos quais saúdo todos aqueles que fizeram ou ainda fazem parte do corpo discente do programa de Pós-graduação em Anatomia dos Animais Domésticos e Silvestres. 
A todos os funcionários da Faculdade de Medicina Veterinária e Zootecnia da USP, em especial aos do Setor de Anatomia: Maicon, Jaqueline, Edinaldo e Diogo. Obrigado pela acolhida, simpatia e auxilio durante todo esse período.

A Coordenação de Aperfeiçoamento de Pessoal de Nível Superior (CAPES) pela bolsa concedida durante o curso.

Ao Conselho Nacional de Desenvolvimento Científico e Tecnológico ( $C N P q)$ pelo financiamento desta pesquisa.

Aos colegas professores do Departamento de Morfologia da Universidade Federal do Rio Grande do Norte, em especial aqueles que fazem parte da primeira base de pesquisa do Departamento: Carlos Augusto Galvão Barboza, Renata Swany Soares Nascimento, Gustavo da Cunha Lima Freire e Raimundo Fernandes de Araújo Júnior.

Enfim, a todos aqueles que contribuirão para realização deste trabalho, meu muitíssimo obrigado.

Emoção eu sei florece Nestes corações amigos

Tantas situações vividas Tão preciosas nunca mais se esquecem

Mas perto estaremos sempre Como que nada hoje aconteceu

Pois o amor brotou sincero

E vai nos conservar num só

Ser amigos é pra sempre como eterno é nosso Deus

Como amigos nós diremos até breve e não adeus Você agora vai partir sobre a mão do pai seguir mas

Amigos nada vai nos separar

Com carinho e fé criados

Pela convivência pura

Nos encontraremos sempre

Na distãncia só o amor perdura

(Composição do Prisma Brasil) 


\section{RESUMO}

MOURA, C. E. B. O bombardeamento da superfície de titânio com íons de argônio influencia a resposta biológica de pré-osteoblastos. [Argon ions bombardment of titanium surface influences preosteoblastic biological behavior]. 2007. 105 f. Tese (Doutorado em Ciências) - Faculdade de Medicina Veterinária e Zootecnia, Universidade de São Paulo, São Paulo, 2007.

As propriedades da superfície do implante têm papel crítico na indução das respostas celulares necessárias para o sucesso do implante. Os objetivos deste trabalho foram investigar o efeito do bombardeamento com íons de argônio sobre a superfície de titânio comercialmente puro (TiCP) e sua influencia na interação célula-superfície. Superfícies bombardeadas e lisas foram avaliadas quanto à topografia, rugosidade e molhabilidade. Ensaios de adesão, proliferação, atividade de fosfatase alcalina (ALP) e expressão de osteocalcina (OC) foram conduzidos usando células MC3T3-E1 cultivadas sobre essas duas diferentes superfícies. Os níveis de rugosidade na superfície bombardeada e lisa foram $0,11 \mu \mathrm{m}$ and $0,027 \mu \mathrm{m}$, respectivamente. A Microscopia eletrônica de Varredura (MEV) e Microscopia de força atômica (AFM) também revelaram rugosidade uniforme nestas amostras. A molhabilidade foi maior na superfície bombardeada. O número de células aderidas (30 e 60 min) foi significativamente maior sobre a superfície bombardeada. A proliferação celular depois de 3 e 7 dias também foi maior na superfície bombardeada. A atividade de ALP e expressão de OC não apresentaram diferença significativa entre as superfícies. Esses dados nos levam a propor que a técnica processamento a plasma em atmosfera de argônio com uso de cátodo planar é uma excelente ferramenta para obtenção de biomateriais que favoreçam a osseointegração.

Palavras-chaves: Implantes dentários. Regeneração óssea. Proliferação celular. 


\section{ABSTRACT}

MOURA, C. E. B. Argon ions bombardment of titanium surface influences preosteoblastic biological behavior. [O bombardeamento da superfície de titânio com íons de argônio influencia a resposta biológica de pré-osteoblastos]. 2007. 105 f. Tese (Doutorado em Ciências) - Faculdade de Medicina Veterinária e Zootecnia, Universidade de São Paulo, São Paulo, 2007.

Titanium surfaces were modified by argon ions bombardment aiming to evaluate the influence of the treatment on cell-surface interaction. The effects of topographic (roughness, microstructure) and physiochemical (wettability - contact angle) parameters on the morphology, adhesion, proliferation and MC3T3-E1 preosteoblasts differentiation were analyzed. No-treated surfaces (smooth) were used as a control. The levels of roughness observed in bombarded and smooth titanium surfaces were of $0.11 \mu \mathrm{m}$ and $0.027 \mu \mathrm{m}$ respectively. Scanning electron microscopy (SEM) and atomic force microscopy (AFM) analysis showed that the roughness distribution was uniform. The wettability increased in treated surfaces. The number of attached cells (30 and 60min) was significantly higher on the bombarded surface, as well as, cell proliferation after 3 and 7 days was also significantly higher on ion-bombarded surface. The ALP activity and OC expression did not show not significant differences between the surfaces. Based on the results showed one can propose that the bombardment of titanium surfaces with argon ions is an excellent procedure for obtaining biomaterials and improve the osseointegration.

Key words: Dental Implants. Regeneration Bone. Cell proliferation. 


\section{LISTA DE FIGURAS}

Figura 1 Delineamento experimental do trabalho.

Figura 2 Esquema representativo do bombardeamento de íons de argônio das superfícies de titânio. A - Câmara hermeticamente fechada; B - Cátodo planar (Fonte: ALVES JR et al., 2006. Imagem cedida pelo autor).

Figura 3 Aparato experimental do Laboratório de Processamento de Matérias a plasma utilizado para tratamento das superfícies de Titânio. A - Câmara hermeticamente fechada. B- Cátodo planar. C- Discos de Ti dispostos sobre o cátodo recebendo o tratamento.

Figura 4 Esquema representativo do aparato utilizado para determinar a molhabilidade das superfícies de Ti (Fonte: SÁ, 2006. Imagem cedida pelo autor)

Figura 5 Fotografia da gota de água sobre o disco de Ti capturada pela câmera acoplada ao aparato de determinação da molhabilidade. Observar as retas traçadas, uma paralela a superfície do disco e a outra tangente a gota, utilizadas para determinar o ângulo de contato $\theta$

Figura 6 Esquema do ângulo de contato (Fonte:SÁ, 2006).

Figura 7 Esquema representativo da captura das imagens dos quadrantes utilizados para avaliar a proliferação das células pré-osteblásticas sobre discos de Ti pelo programa analisador de imagens.

Figura 8 Imagens da gota de água sobre os discos de Ti capturada pela câmera acoplada ao aparato de determinação da molhabilidade. A- Superfície bombardeada; B- Superfície lisa. Observar imediata acomodação da água na superfície bombardeada. Sup= superfície metálica e $\mathrm{g}=$ gota de água.

Figura 9 Medida dos ângulos médios de contato da gota de água e de glicerol nas superfícies de Ti tratada a plasma em atmosfera de argônio (texturizada) e apenas polidas (lisa). *diferença significativa entre os grupos ( $p<$ $0.05)$

Figura 10 Rugosidade média $(\mathrm{Ra})$ das superfícies de $\mathrm{Ti}$ lisa e tratada a plasma em atmosfera de argônio

Figura 11 Fotografia das superfícies dos discos de Ti obtidas no microscópio de luz refletida. A- Superfície lisa do disco após polimento. B - Amostra 
bombardeada com íons de argônio. Observar as rugosidades uniformes na superfície.....

Figura 12 Eletrofotomicrografias das superfícies de Ti. A - Topografia da superfície de Ti lisa. B- Observar textura rugosa com precipitados dispersos da superfície bombardeada com argônio.

Figura 13 Imagens representativas das categorias de cometas resultantes dos danos ao DNA nas células CHO-K1. 0 - 1 são indicativos dos níveis de lesão ao 70 DNA, vai de 0 que corresponde ao nucleóide sem dano até 4 , maior nível de lesão ao DNA

Figura 14 Freqüências médias de células CHO-K1 que apresentaram danos no DNA de acordo com os níveis de lesões, avaliados por meio do teste de cometa sobre as superfícies de Titânio. * indica diferença significativa $(P<0.05) \ldots .$.

Figura 15 Fotomicrografias das células pré-osteoblásticas sobre as região de transição (região entre o centro e periferia) dos discos de Titânio obtidas em microscópio de luz refletida após 11 dias de cultura. A - Observar as que as células possuem um menor tamanho, formas mais poligonais $e$ marcadas por vários prolongamentos (seta vazia). A seta cheia indica um risco provocado por pinça para remover biofilme que estava aderido a superfície de Ti bombardeada. B - Células maiores, porém com forma mais regular. A seta indica o biofilme produzido pelas células.

Figura 16 Células pré-osteblásticas (CPO) cultivadas por 3, 7 e 11 dias sobre discos de Ti bombardeados por argônio e lisos. As imagens A, B e C são de CPO cultivadas por 3, 7 e 11 dias em superfícies tratadas, respectivamente. Em $\mathrm{D}$, observar célula poligonal marcadas por vários prolongamentos. Enquanto as imagens $E$ - $G$ foram obtidas de CPO sobre superfície lisa cultivadas nos mesmos tempos. Na figura F, há CPO maiores e com formato arredondado na superfície lisa.

Figura 17 Coeficiente do fator forma dos pré-osteoblastos cultivados por $72 \mathrm{~h}$ sobre Ti bombardeado com íons de argônio e Ti liso. O fator forma é definido como [(área/perímetro2) $\times 4 \pi$ ], quando igual a 1 refere-se a um circulo e 0 a uma reta. Quanto menor o fator forma mais alongadas são as células. Cada barra representa a média \pm desvio padrão do coeficiente do fator forma de 100 células de cada tratamento. * $p<0,0001$ indica diferença estatisticamente significativa.

Figura 18 Distribuição relativa dos tipos I, II e III de pré-osteoblastos em função do substrato. Cada barra corresponde à média \pm desvio padrão da porcentagem dos tipos celulares representativos, obtidos a partir de 100 células de cada tratamento. O tipo I predominou no Ti bombardeado, enquanto o II na superfície lisa. As células tipo III não foram encontradas na superfície bombardeada. Células cultivadas sobre a superfície bombardeada foram significativamente mais alongadas com numerosas extensões celulares comparada com a lisa. * indica diferença significativa $(p<0,001)$. 
Figura 19 Imagens de microscopia de força atômica de células pré-osteblásticas e sua matriz extracelular sobre a superfície de discos de Ti bombardeadas com íons de argônio. (a) Células pré-osteblásticas com forma mais arredondada no 3 dia de cultura $\left({ }^{*}\right)$. (b) Observar maior rugosidade aos 7 dias. (c) Células com formato mais poligonal e marcada por vários prolongamentos $(\rightarrow)$.

Figura 20 Imagens de microscopia de força atômica de células pré-osteblásticas e sua matriz extracelular sobre a superfície de discos de Ti não-tratadas. (a) Células pré-osteblásticas com forma mais arredondada nos 3 e 7 dia de cultura $\left(^{*}\right)$. (b) Observar células pré-osteoblásticas ainda arredondadas aos 7 dias $\left(^{*}\right)$. (c) Maior rugosidade e células com formato arredondado.

Figura 21 Histograma da proliferação celular expressa em número de células por $\mathrm{cm} 2$ depois de 3,7 e 11 dias. Cada barra representa a média de préostesblastos \pm desvio padrão ( $n=3$ em cada grupo) de três experimentos iguais. * $p<0,001$ compara Ti bombardeado e liso; ${ }^{* *} p<0,001$ compara controle e Ti bombardeado.

Figura 22 Histograma da proliferação celular expressa em número de células por $\mathrm{cm} 2$ depois de 3,7 e 11 dias. Cada barra representa a média de préostesblastos \pm desvio padrão ( $n=3$ em cada grupo) de três experimentos iguais de contagem celular no sistema analisador de imagem. * indica diferença estatística entre as superfícies $p<0,001$

Figura 23 Histograma do conteúdo de proteína total ( $\mu \mathrm{g} /$ células) normalizado para o número de células depois de 3,7 e 11 dias. * Indica diferença estatisticamente significativa entre controle e superfícies de Ti; ${ }^{* *}$ Mostra diferença entre as superfícies. Dados referentes a média \pm desvio padrão ( $n=3$ para cada grupo).

Figura 24 Histograma da densidade óptica (OD) de células pré-osteoblásticas aderidas nas superfícies de Ti. Cada barra representa a média das OD de células pré-osteoblásticas \pm desvio padrão $(n=3$ em cada grupo) de três experimentos iguais. * Indica diferença estatisticamente significativa entre as superfícies de Ti.

Figura 25 Atividade de fosfatase alcalina (ALP) no meio condicionado de préosteoblastos sobre superfícies de $\mathrm{Ti}$ e no plástico de placas de cultura (controle) durante $3,7,11$ e 14 dias de cultivo. a-b diferença estatística entre as superfícies de $\mathrm{Ti}$ e o plástico da placa de cultura aos 14 dias.

Figura 26 Expressão de osteocalcina. A- células positivas para este marcador e BIntensidade de fluorescência para osteocalcina de células cultivadas sobre diferentes superfícies e avaliadas por citometria de fluxo após 14 dias de cultura. a-c diferença estatística $(p<0,05)$. $\mathrm{C}-\mathrm{N}=$ controle negativo (células sobre o plástico que não receberam fatores osteoindutores (ácido ascórbico e $\beta$-glicerofosfato); $\mathrm{C}-\mathrm{P}=$ controle positivo (células sobre o plástico e meio com fatores osteoindutores); $T i-L=$ média de células positivas cultivadas sobre superfície de $\mathrm{Ti}$ lisa e Ti-B= média de células positivas cultivadas sobre superfície de Ti bombardeada 


\section{LISTA DE TABELAS}

Tabela 1 Reversão de cepas de Salmonella typhimurium no teste de Ames em superfícies de titânio tratadas a plasma e não-tratadas - São Paulo 2007.

Tabela 2 Número médio de células que apresentaram danos ao DNA de acordo com os níveis de lesões, avaliados por meio do teste de cometa em células CHO-K1 sobre as superfícies de Titânio - São Paulo 2007

Tabela 3 Rugosidade média ( $\mathrm{Ra}$ ) em $\mu \mathrm{m}$ obtida pelo AFM das células préosteblásticas e sua matriz sobre as superfícies de Ti bombardeada e lisa - São Paulo - 2007. 


\section{LISTA DE ABREVIATURAS E SIGLAS}

\begin{tabular}{|c|c|}
\hline AFM & Microscopia de força atômica \\
\hline $\mathrm{Al}_{2} \mathrm{O}_{3}$ & Óxido de alumínio \\
\hline ALP & Fosfatase alcalina \\
\hline ASD & Dispositivo anódico de faísca \\
\hline ATT & Dispositivo anódico alcalino \\
\hline BMP & Proteína morfogenética óssea \\
\hline CA & Adesão celular \\
\hline $\mathrm{CHO}$ & Células do ovário de hamster chinês \\
\hline $\mathrm{C}-\mathrm{N}$ & Controle negativo \\
\hline C-P & Controle positivo \\
\hline $\mathrm{CPO}$ & Células pré-osteoblásticas \\
\hline CPT & Conteúdo de proteína total \\
\hline Cr-Co & Liga de cromo-cobalto \\
\hline$d_{c c}$ & Distância entre cátodos \\
\hline DEIV 3E & Detergente enzimático \\
\hline DLC & Carbono tipo diamante \\
\hline EDTA & Ácido dietilenodiaminotetracético \\
\hline FF & Fator forma \\
\hline $\mathrm{H}_{2} \mathrm{O}_{2}$ & Peróxido de hidrogênio \\
\hline MEV & Microscopia eletrônica de varredura \\
\hline Mol & Unidade de base do Sistema Internacional de Unidades (SI) para \\
\hline & a grandeza quantidade de matéria ou quantidade de substância. \\
\hline $\mathrm{mg}$ & miligrama \\
\hline$\mu g$ & Micrograma \\
\hline $\mathrm{Ni}-\mathrm{Cr}$ & Liga de níquel-cromo \\
\hline $\mathrm{O}_{2}$ & Oxigênio \\
\hline OD & Densidade óptica \\
\hline OP-S & Solução de sílica coloidal \\
\hline PBS & Solução salina tamponada \\
\hline PCR & Reação de polimerase em cadeia \\
\hline $\mathrm{pH}$ & Potencial hidrogeniônico \\
\hline PLD & Dispositivo laser pulsátil \\
\hline pNPP & p-nitrofenilfosfato \\
\hline
\end{tabular}




$\begin{array}{ll}\text { Ra } & \text { Rugosidade média } \\ \text { RM } & \text { Razão de mutagenicidade } \\ \text { SFB } & \text { Soro fetal bovino } \\ \text { TA 100 } & \text { Linhagem de Salmonella Typhimurium } \\ \text { TA 98 } & \text { Linhagem de Salmonella Typhimurium } \\ \text { Ti } & \text { Titânio } \\ \text { Ti6Al4V } & \text { Liga de titânio-alumínio-vanádio } \\ \text { Ti-Ag } & \text { Liga de titânio-prata } \\ \text { Ti-B } & \text { Titânio bombardeado } \\ \text { TiC } & \text { Superfície de titânio coberta com carbono } \\ \text { Ti-Co } & \text { Liga de titânio-cobalto } \\ \text { TiCP } & \text { Titânio comercialmente puro } \\ \text { Ti-L } & \text { Titânio liso } \\ \text { TiO } 2 & \text { Óxido de titânio } \\ \text { TPS } & \text { Plasma de titânio } \\ \text { UA } & \text { Unidades arbitrárias } \\ \text { a-MEM } & \text { Meio essencial mínimo }\end{array}$




\section{SUMÁRIO}

1 INTRODUÇÃO

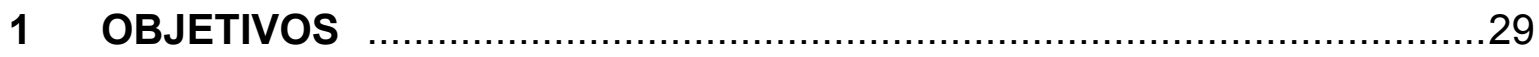

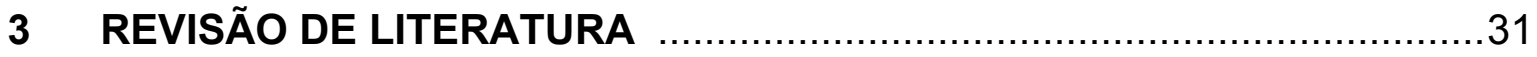

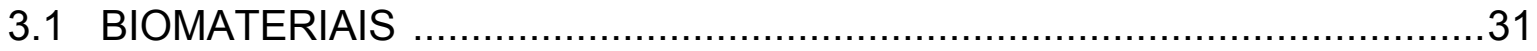

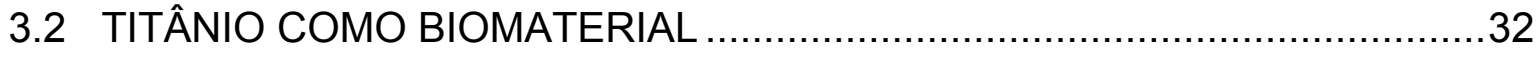

3.3 MECANISMO DE OSSEOINTEGRAÇÃO E O TITÂNIO ………………........35

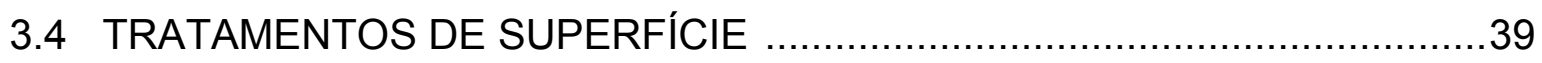

3.5 PROPRIEDADES DA SUPERFÍCIE E A OSTEOINTEGRAÇÃO .................41

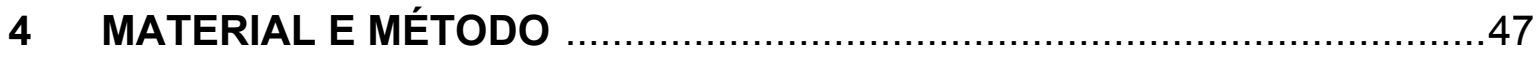

4.1 PREPARAÇÃO DOS DISCOS DE TITÂNIO ………............................48

4.2 CARACTERIZAÇÃO DA SUPERFÍCIE ……….................................50

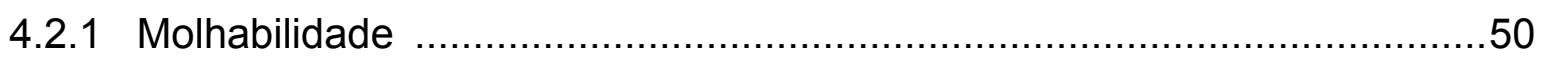

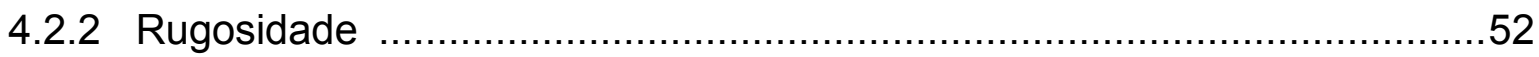

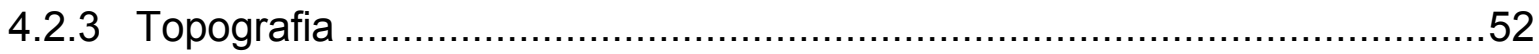

4.3 OBTENÇÃO E CULTURA DAS CÉLULAS ……........................................53

4.3.1 Cultura das células pré-osteoblásticas ..................................................53

4.3.2 Cultura das células de ovário de hamster chinês $(\mathrm{CHO}) \ldots \ldots \ldots \ldots \ldots \ldots \ldots \ldots \ldots . . . .63$

4.4 GENOTOXICIDADE E MUTAGENICIDADE DO BOMBARDEAMENTO DO Ti

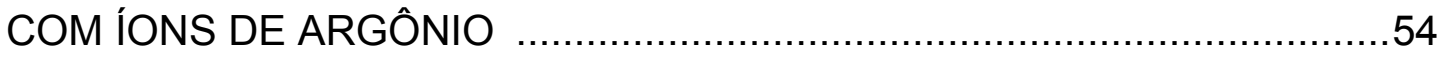

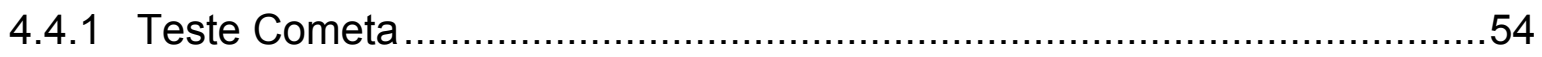

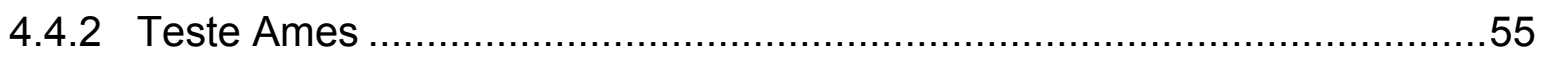

4.5 MORFOLOGIA DOS PRÉ-OSTEOBLASTOS SOBRE AS SUPERFÍCIES $\mathrm{DE} \mathrm{Ti}$ 
4.5.1 Microscopia óptica de luz refletida .57

4.5.2 Microscopia eletrônica de varredura (MEV) e proliferação celular .57

4.5.3 Microscopia de força atômica (AFM) .58

4.6 PROLIFERAÇÃO DOS PRÉ-OSTEOBLASTOS SOBRE AS SUPERFÍCIES

DE Ti .58

4.7 ADESÃO DOS PRÉ-OSTEOBLASTOS SOBRE AS SUPERFÍCIES DE Ti .60

4.8 DIFERENCIÇÃO DOS PRÉ-OSTEOBLASTOS SOBRE AS SUPERFÍCIES $\mathrm{DE} \mathrm{Ti}$ 60

4.8.1 Atividade de fosfatase alcalina 60

4.8.2 Análise de citometria de fluxo para osteocalcina 61

4.9 ANÁLISE ESTATÍSTICA .62

5 RESULTADOS .64

5.1 CARACTERIZAÇÃO DAS SUPERFÍCIES DE Ti .64

5.1.1 Molhabilidade .64

5.1.2 Rugosidade 65

5.1.3 Topografia .66

5.2 GENOTOXICIDADE E MUTAGENICIDADE DAS SUPERFÍCIES DE Ti 69

5.2.1 Teste Ames .69

5.2.2 Teste Cometa .70

5.3 MORFOLOGIA DOS PRÉ-OSTEBLASTOS .71

5.3.1 Microscopia de Luz refletida e Eletrônica de varredura .72

5.3.2 Microscopia de Força Atômica .75

5.4 PROLIFERAÇÃO DOS PRÉ-OSTEOBLASTOS SOBRES AS SUPERFÍCIES DE $\mathrm{Ti}$ 79

5.5 ADESÃO DOS PRÉ-OSTEOBLASTOS SOBRE AS SUPERFÍCIES DE Ti ..81 
5.6 DIFERENCIAÇÃO DOS PRÉ-OSTEOBLASTOS SOBRE AS SUPERFICIES $\mathrm{DE} \mathrm{Ti}$ .81

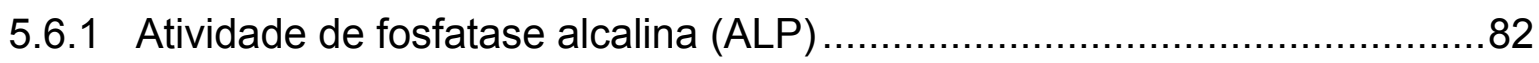

5.6.2 Análise de citometria de fluxo para osteocalcina ..................................83

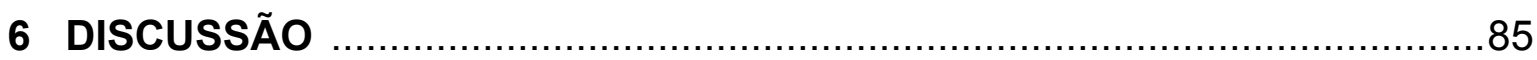

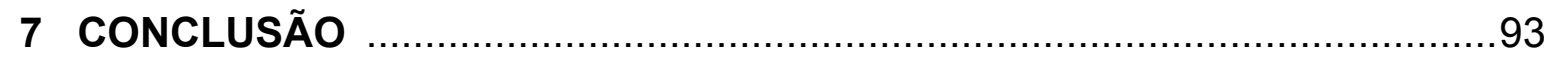

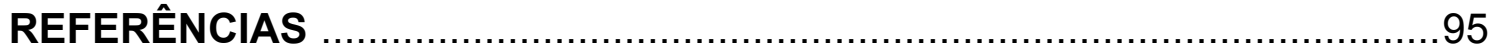


Introdução 


\section{INTRODUÇÃO}

Implantes de dispositivos produzidos a partir de uma grande variedade de biomateriais naturais ou sintéticos são uma das ferramentas mais importantes para reparar lesões traumáticas, processos infecciosos, neoplasias ou anomalias de desenvolvimento (TWEDEN et al., 1995). O sucesso clínico dos implantes depende da interação entre as células do organismo implantado e a superfície do biomaterial utilizado (ZREIQAT et al., 2005).

Molhabilidade, textura, composição química e rugosidade da superfície são propriedades do biomaterial que influenciam diretamente sua interação com as células (DELIGIANNI et al., 2001): desde adesão inicial das células, até deposição e o arranjo das proteínas e proteoglicanas da matriz extracelular (SCHWARTZ et al., 1996; KLINGER et al., 1998). O arranjo tridimensional da matriz extracelular, por sua vez, influencia diretamente os processos de adesão, proliferação, e diferenciação celular (LINCKS et al., 1998). Portanto, as propriedades da superfície do biomaterial são determinantes para a resposta das células na interface célulabiomaterial, conseqüentemente, afetando o crescimento e a qualidade do tecido neoformado (DELIGIANNI et al., 2001).

Entre os vários biomateriais, o titânio comercialmente puro (TiCP) é o mais utilizado como matéria prima de implantes na ortopedia e odontologia, devido a sua biocompatibilidade e propriedades mecânicas, como durabilidade e usinabilidade (BÄCHLE;KOHAL, 2004; IMWINKELRIED, 2007;). Entretanto, o titânio não é um biomaterial ideal e vários grupos têm usado diferentes tratamentos para modificar a topografia e a composição química da superfície do titânio com objetivo de produzir biomateriais mais osseointegráveis (DEYNEKA et al., 2007). Com este intuito, a rugosidade da superfície tem sido uma das propriedades melhor estudadas, pois ela possui um papel fundamental na regulação da adesão, forma e conseqüentemente na proliferação celular (ZHU et al., 2004).

O tipo de superfície dos implantes, rugosa ou lisa, influencia o mecanismo de osseointegração. Em função disto, tem-se realizado trabalhos com a finalidade de se obter uma superfície ideal, que favoreça o mecanismo de osseointegração, sem modificar os tecidos adjacentes ou promover reações de rejeição. No entanto, na literatura ainda existem controvérsias quanto à resposta celular frente à rugosidade 
da superfície. Alguns estudos mostram que superfícies rugosas aumentam o crescimento de tecido ósseo ao redor do implante por favorecerem a deposição e melhor distribuição de proteínas na superfície do implante (HATANO et al., 1999). Outros autores afirmam que superfícies lisas favorecem a proliferação celular (STANFORD et al., 1994).

Outra importante propriedade de uma superfície é molhabilidade, capacidade relacionada à adsorção de água pela superfície (LIM et al., 2001). Como o sangue é o primeiro tecido que entra em contato com o implante, e este possui uma composição hídrica de aproximadamente 90\%, esta capacidade de adsorção de água pela superfície torna-se fundamental para o sucesso da adesão celular $\mathrm{e}$ conseqüente osseointegração (KASEMO, 2002). A avaliação da molhabilidade de uma superfície pode ser realizada pela determinação do ângulo de contato. Ele é definido como o ângulo formado entre a superfície sólida e a tangente à superfície do líquido no ponto de contato dos dois. $\mathrm{O}$ ângulo de contato pode variar de 0 a 180 graus. Quanto menor esse ângulo, mais molhável é a superfície (KWOK et al., 1998).

As superfícies rugosas são produzidas a partir de processos de subtração incluindo o condicionamento ácido de superfície, jateamento, o mecanismo de promoção da rugosidade superficial produzido por laser e a aplicação de revestimentos de hidroxiapatita (SPIEKERMANN et al., 2000). Entretanto, dentre os diferentes métodos existentes, aqueles que utilizam o plasma como fonte energética são os que mais avançaram nos últimos anos, devido, principalmente, a sua versatilidade (ALVES JR., et al., 2006). O plasma é gerado aplicando-se uma voltagem entre dois elétrodos em um sistema hermeticamente fechado com pressão suficientemente baixa. Elétrons e íons são acelerados no campo elétrico, colidindo com outras partículas, produzindo íons adicionais e elétrons em uma reação em cadeia. Ocorre o bombardeamento dos átomos da superfície produzindo defeitos na superfície do disco (SILVA et al., 2006). Essa técnica permite produzir uma textura uniforme nas superfícies, devido à facilidade do controle da rugosidade, quer seja através do aumento da energia de bombardeamento e/ ou número de íons bombardeantes, pode ser considerada adequada para estudos sistemáticos de modificação de superfície de biomateriais (ALVES JR., et al., 2006 ).

Hipotizou-se que a superfície de titânio tratada por plasma com o uso de cátodo planar apresente biocompatibilidade adequada para implante. $O$ presente 
trabalho, portanto, objetivou avaliar a adesão, proliferação e diferenciação de préosteblastos sobre superfícies de discos de titânio modificadas por plasma em atmosfera de argônio com o uso de cátodo planar. 
Objetivos 


\section{OBJETIVOS}

O objetivo geral é avaliar a resposta de pré-osteoblastos e a biocompatibilidade da superfície de TiCP bombardeada por íons de argônio, por meio de testes de mutagênese e genotoxicidade. Para tal, os seguintes objetivos específicos foram determinados:

- Caracterizar a molhabilidade, rugosidade e topografia da superfície de TiCP bombardeada por íons de argônio.

- Avaliar o potencial genotóxico e mutagênico da superfície de TiCP bombardeada por íons de argônio.

- Caracterizar a morfologia de pré-osteblastos cultivados sobre as superfícies de TiCP bombardeadas.

- Avaliar a influência das propriedades da superfície sobre a adesão, proliferação e diferenciação de pré-osteblastos da linhagem MC3T3E1. 
Revisão de Literatura 


\section{REVISÃO DE LITERATURA}

Neste capitulo será apresentada uma breve abordagem de aspectos importantes sobre o titânio como biomaterial, suas propriedades e os tratamentos de superfície aplicados a este material na busca de superfícies implantares osteointegráveis.

\subsection{BIOMATERIAIS}

Biomaterial é definido cientificamente como qualquer substância ou combinação de substâncias que não sejam drogas ou fármacos, de origem natural ou sintética, que podem ser usadas por qualquer que seja o período de tempo, como parte ou como o todo de sistemas que tratam, aumentam ou substituem quaisquer tecidos, órgãos ou funções do corpo (TWEDEN et al., 1995).

Há várias décadas eram utilizados diversos tipos de materiais como ouro, marfim, madeira, osso esculpido, dentes humanos e de animais, com a finalidade de substituir dentes perdidos ou outras perdas teciduais consideráveis provocadas por traumatismos ou processos patológicos (SPIEKERMANN et al., 1995). Com a evolução do conhecimento humano e o progresso tecnológico, diversos materiais têm sido testados buscando-se preservar a integridade tecidual através da utilização de materiais biocompatíveis.

Atualmente, os biomateriais podem ser metálicos, poliméricos ou cerâmicos, dependendo da aplicação, das propriedades mecânicas e processabilidade requeridas. Os principais deles utilizados em implantes são, na maioria, materiais metálicos como aço inoxidável, ligas de cromo-cobalto ( $\mathrm{Cr}-\mathrm{Co}$ ), titânio (considerado um material ainda com pouco tempo de experiências em aplicações protéticas) e o óxido de titânio, um biomaterial recente (IMWINKELRIED, 2007; WENGEN, 2007). 
Os biomateriais devem apresentar propriedades essenciais para serem utilizados como implantes: biocompatibilidade, biofuncionalidade, bioadesão, propriedades mecânicas adequadas, processabilidade e preços compatíveis com a realidade sócio-econômica de cada país (BREME, 1988).

O conceito de biocompatibilidade evoluiu e não mais se supõe que materiais biocompatíveis devam ser absolutamente inertes e inócuos, mas que as respostas induzidas no organismo hospedeiro sejam controláveis pelo sistema e pelo todo. Portanto, biocompatibilidade é uma característica do material que quando usado em aplicações especificas, desenvolve respostas teciduais adequadas no hospedeiro (HSU et al., 2007).

Uma propriedade essencial de um biomaterial é a biofuncionalidade, que pode ser definida como sendo a capacidade de um dispositivo funcionar com uma reposta apropriada do hospedeiro em uma aplicação específica (BRAMA et al., 2007).

A bioadesão é obtida com o uso de um material bioativo, o qual produz a união entre $o$ implante e o osso. O implante precisa ter uma estrutura micromorfológica que deve ser obtida pela produção de rugosidades ou porosidades no material, não só para assegurar a ligação do osso à superfície do implante, como também, ativar a osseointegração. A melhor bioadesão possível ocorre quando se tem a osteogênese, na qual ocorre uma união físico-química do material ao osso. Esse tipo de união também é denominada de união anquilótica, ou seja, o implante não pode ser separado por meios mecânicos do osso sem que haja fratura neste (BOSCHI,1996).

\subsection{TITÂNIO COMO BIOMATERIAL}

Quando em estado sólido, o titânio é um metal com aparência do aço. Em forma de pó, possui coloração de cinza a preta. É o nono elemento mais abundante na Terra, constituindo cerca de $0,63 \%$ da crosta terrestre. Entre os metais, sua abundância é inferior apenas a do alumínio, ferro e magnésio (ZHANG; HENRICH, 
1992). As grandes reservas deste metal encontram-se no Canadá, Austrália e Estados Unidos da América. Do total extraído, a maior parte é transformada em pigmentos de dióxido de titânio para uso na fabricação de tintas e na indústria de cosméticos para confecção de filtro solar; apenas 5 a $10 \%$ são utilizados na sua forma metálica (GUERRA NETO, 2005).

O elemento titânio pode associa-se a outros metais para formar ligas, entre os quais estão: prata, alumínio, arsênico, cobre, ferro, gálio, urânio, vanádio e zinco. A adição de quantidades em traços de elementos como carbono, oxigênio, nitrogênio e ferro podem melhorar significativamente as propriedades mecânicas do titânio puro. A maioria dos produtos de TiCP contém traços de alguns desses elementos (ALBREKTOSSONT, 1983)

As aplicações do titânio e suas ligas na área biomédica incluem desde bombas e dispositivos de corações artificiais a aplicações mais estruturais como parafusos e pinos em implantes odontológicos e próteses ósseas para braços, pernas e articulações (GORRIERI et al., 2006; LANDES et al., 2006; MEROLLI et al., 2006; BAGNO et al., 2007; BRAMA et al., 2007; GJURIC; RUKAVINA, 2007). Diversos autores (IMWINKELRIED, 2007) têm demonstrado a superioridade do titânio como biomaterial quando comparado a outros metais.

A biocompatibilidade, resistência ao desgaste e à corrosão e sua dureza, tornam o titânio o metal mais utilizado na implantologia. Algumas dessas propriedades do Ti pode ser explicadas pela estabilidade química ocasionada por um recobrimento de óxido (HULTH, 1980; KASEMO, 1983; MALO et al., 2006; RIDLEY et al., 2006; DE OLIVEIRA et al., 2007; DEYNEKA et al., 2007; MUHONEN et al., 2007). Quando usinado, o TiCP é exposto de forma repentina a uma atmosfera de ar e substâncias lubrificantes e resfriadoras, tornando-o susceptível à dissociação das moléculas de oxigênio do ar, o que resulta na formação extremamente rápida de óxido em sua superfície (KASEMO, 2002)

A camada de óxido de titânio $\left(\mathrm{TiO}_{2}\right)$ que se forma na superfície do titânio é semicondutora e previne a troca de elétrons e qualquer reação de redução na superfície. Desta forma, os produtos de corrosão nos tecidos não estão em forma de íon e sim como óxidos estáveis (MUHONEN et al., 2007). Em meios fisiológicos, a camada de óxido é altamente protetora prevenindo o contato entre o meio e o metal 
base. Isso significa que não existe o contato direto entre o metal e seus tecidos hospedeiros, mas certamente entre o tecido e a superfície de óxido formada (KASEMO, 1983). O processo químico, chamado de corrosão, que representa um problema para alguns materiais de implantes, parece ser mais lento com o titânio, provavelmente devido à alta estabilidade de seus óxidos (HULTH, 1980; KASEMO, 1983; DE OLIVEIRA et al., 2007; DEYNEKA et al., 2007).

Até o momento, não foi identificada com exatidão, a primeira camada de biomoléculas que se depositam na superfície do implante após sua imediata implantação. A hidratação do óxido provavelmente é um importante processo no estabelecimento de um ambiente químico apropriado para adsorção destas biomoléculas (HEALY; DUCHEYNE, 1992). Por meio de ligações do tipo Van der Walls, forças covalentes, iônicas e ligações de hidrogênio. Estas moléculas podem se ligar à superfície do biomaterial (PARSEGIAN, 1983). É clara a influência da superfície do implante no sucesso ou falha da implantação. É importante que o implante não tenha um efeito sobre a desnaturação das proteínas na superfície. Isso ocorrerá dependendo do tipo e da resistência da união entre a proteína e a superfície. Uniões muito fortes alteram a conformação protéica e ocasionam desnaturação e se, pelo contrário, forem levemente afetadas, as proteínas permanecerão na sua conformação original (KASEMO, 2002).

Como mencionado, as moléculas protéicas unem-se à superfície de óxido, e a natureza da interação entre a superfície mais externa de átomos do implante e as proteínas (e/ou outras biomoléculas) é crucial para resposta do sistema biológico ao implante. Tanto a microarquitetura (microgeometria e rugosidade) da superfície quanto sua composição química são importantes pelas seguintes razões (IMWINKELRIED, 2007; WENGEN, 2007):

1- Superfícies lisa, curva ou rugosa causam diferentes áreas de contato com biomoléculas e células. As diferentes áreas de contato produzem diferentes tipos de ligações de unidades biológicas que podem influenciar sua conformação e função.

2- Variações na composição química das superfícies produzem tipos diferentes de união às biomoléculas. 
Um fator essencial, nesse contexto, é como a superfície do material interage com a água. Quando se liga fortemente à água, denomina-se superfície hidrofillica. Neste caso, as proteínas reconhecem a superfície como similar à água. As proteínas provavelmente interagirão com o material indiretamente, através da intermediação da camada de água e permanecerão no seu estado conformacional normal. Se, ao contrário, a superfície repelir ou tiver uma ligação frágil com a água, ou seja, for uma superfície hidrofóbica, as proteínas estarão mais próximas a formar ligações diretamente com átomos da superfície, os quais poderão causar mudanças conformacionais ou desnaturação (KASEMO, 2002).

No período inicial, após implantação, existe essencialmente água, íons dissolvidos e biomoléculas livres na região mais próxima da superfície. A composição do biolíquido se modifica continuamente, conforme o processo inflamatório de cicatrização progride, o que provavelmente causa mudanças na composição da camada de biomoléculas adsorvidas na superfície do implante durante as primeiras semanas. Eventualmente, células se aproximam da superfície e dependendo da natureza das camadas adsorvidas, respondem de forma específica, podendo ainda modificá-la. Com o tempo, os tipos de células mais próximas às superfícies e suas atividades podem mudar, dependendo do tipo de interação inicial. Assim, o resultado final pode ser a formação de uma cápsula fibrosa ou a ossoeintegração (KASEMO, 2002).

\subsection{MECANISMO DE OSSEOINTEGRAÇÃO E O TITÂNIO}

O primeiro tecido a entrar em contato com o implante é o sangue, cujo volume vai variar em função da geometria do implante e do sítio cirúrgico. O coágulo sofre uma série de eventos biológicos que terminarão na formação de tecido ósseo ao redor do implante (MASUDA et al., 1997).

A todo o momento, o material está condicionado pelos componentes do fluido onde está inserido, seja soro, saliva, ou meio de cultura de células. A superfície do biomaterial está coberta com uma mistura de lipídios, carboidratos, íons e proteínas 
específicas para a composição química, topografia e a densidade de carga do substrato. As características da superfície determinam quais moléculas irão adsorver, ao passo que a natureza e orientação dessas biomoléculas terão conseqüências diretas no recrutamento, ancoragem, proliferação e diferenciação das células. A ancoragem das células requer a presença de proteínas de ligação específicas, enquanto a proliferação e diferenciação requerem a presença de fatores de crescimento e citocinas (KIESWETTER et al., 1996).

Quando o osso é traumatizado por ocasião da inserção do implante, ocorre a formação de um coágulo. É necessária também a formação de uma certa quantidade de tecido conjuntivo e capilares. O trauma operatório sensibiliza células que liberam determinados fatores de crescimento que estimularão novas células. $O$ equilíbrio entre a formação de tecidos moles e do novo osso é influenciado pelos mediadores liberados por estas células. Esse equilíbrio entre os elementos teciduais envolvidos é que dita o sucesso ou não da reparação. Influências externas como aplicação de carregamento antes do tempo, alterações de $\mathrm{pH}$ ou da saturação de $\mathrm{O}_{2}$ podem perturbar a reparação óssea (MASUDA et al., 1997).

Brånemark et al. (1969) foram os primeiros a sugerirem a possibilidade de uma ancoragem direta do titânio ao osso. Posteriormente, Brånemark et al. (1977) criaram o termo osseointegração para designar a relação direta entre ambos, observada através de microscopia óptica. Esse termo passou por algumas modificações e, mais tarde, em 1991, Zarb e Albrektsson redefiniram a osseointegração como fixação rígida e assintomática entre o tecido ósseo e o implante em estado funcional.

O processo de osseointegração é descrito por Campos Júnior e Passanezi (1996) em três estágios. Estágio 1: o osso perfurado não é perfeitamente congruente com o implante. Implantes rosqueados têm como objetivo a imobilização do implante no osso imediatamente após a colocação e durante o período inicial de cicatrização. O hematoma presente nas cavidades da rosca do parafuso e a camada de osso danificado se originam do trauma mecânico e térmico durante a operação. Estágio 2: durante a cicatrização sem carga, o hematoma é gradualmente transformado em novo osso e a região do osso danificado também é cicatrizado por um processo de revascularização, desmineralização e remineralização. Estágio 3: quando a 
cicatrização se completa, o osso neoformado estará praticamente em contato direto com o implante sem nenhuma camada intermediaria de tecido fibroso. $\mathrm{O}$ osso em contato com o implante se regenera em resposta à pressão aplicada, como por exemplo, em uma carga mastigatória.

Grande número de estudos tem sido realizado com o objetivo de se conhecer melhor os mecanismos da osseointegração (JAYARAMAN et al., 2004; PALMA et al., 2005; GRÖSSER-SCHREIBER et al., 2006; CHIN et al., 2007; EISENBARTH et al., 2007). Em meados da década de 80, também foi observado um tecido fibroso entre o implante e o osso, o que foi denominado de fibroosseointegração (WEISS, 1987). Entretanto, a falta de previsibilidade e os altos índices de insucessos para implantes dentais mantidos pelo mecanismo de fibroossoeintegração levaram muitos autores a questionarem a importância deste mecanismo (ALBREKTSSON, 1983; ALBREKTSSON, 1988).

Em contrapartida, elevadas taxas de sucesso e uma melhor previsibilidade para os tratamentos realizados através de próteses suportadas por implantes osseointegrados levaram ao aumento da credibilidade deste tipo de tratamento, promovendo um incentivo para as pesquisas relacionadas a esse assunto (GORRIERI et al., 2006; SOHN et al., 2006).

Dos materiais utilizados na fabricação de implantes dentários, há três tipos de biomateriais que são especialmente usados na prática: metais e ligas (principalmente titânio e Ti6Al4V); cerâmicas (incluindo trióxido de alumínio e fosfato de cálcio); e os polímeros (polimetilmetacrilato e polisulfona, LEMONS, 1990).

Segundo Kohn (1992) o sucesso dos implantes osseointegrados está relacionado ao biomaterial, seus fatores biomecânicos, que englobam o material utilizado, processo de fabricação, mecanismos de interação com o leito receptor, suas propriedades mecânicas, desenho do implante, tipo de carga aplicada, características teciduais, estabilidade inicial, mecanismos de obtenção e manutenção da osseointegração, além da biocompatibilidade e química de superfície (GORRIERI et al., 2006; SALATA et al., 2007). 
Para Hobo et al. (1997) outros fatores que afetam a osseointegração incluem a contaminação da camada de óxidos do implante e a falta de controle da temperatura durante a confecção do leito receptor. Segundo esses autores, o osso maduro é sensível ao calor, e a temperatura específica crítica foi identificada como $56^{\circ} \mathrm{C}$. Além desta temperatura, ocorrem danos irreversíveis ao tecido ósseo e a osseointegração não ocorre.

Nas áreas médica e odontológica, a utilização do TiCP e a liga titânioalumínio-vanádio (Ti6Al4V, ou seja: 90\% de Titânio, $6 \%$ de alumínio e 4\% de vanádio, dados em percentagem/peso) (LAUTENSCHLAGER; MONAGHAN, 1993), têm destaque em função da sua alta resistência à corrosão, decorrente da camada de óxidos que se forma na superfície do material ao entrar em contato com o ar ou água (KASEMO, 1983; GORRIERI et al., 2006; MUHONEN et al., 2007).

O delgado filme de óxidos da superfície do titânio é, provavelmente, responsável pela excelente biocompatibilidade desse material devido ao seu alto nível de condutbilidade elétrica, alta resistência à corrosão e um nível termodinâmico estável em pH fisiológico (KASEMO, 1983; GORRIERI et al., 2006; MUHONEN et al., 2007). No entanto, segundo Sawase et al. (1998), a espessura e a composição dessa camada de óxidos depende das condições de fabricação dos implantes.

A camada de óxidos pode ter sua composição, espessura e microestrutura alteradas por processos de usinagem, limpeza e esterilização (MUHONEN et al., 2006). No entanto, segundo Schröeder et al. (1981), em termos de biocompatibilidade, as propriedades do óxido de superfície são mais importantes do que o metal.

A obtenção e manutenção da osseintegração em longo prazo, ainda mostram sinais da necessidade de se desenvolver um implante que apresente adequadas características de forma, tipo e arquitetura das roscas, morfologia e composição química da superfície, que permitam considerável adesão dos tecidos ósseo, conjuntivo e epitelial (WEBER; FIORELLINI, 1992). 


\subsection{TRATAMENTOS DE SUPERFÍCIE}

O objetivo dos tratamentos de superfícies é o estabelecimento de uma ligação química e mecânica do osso ao material do implante. Geralmente objetiva-se a criação de uma superfície rugosa onde é feita a aposição mecânica do osso.

Atualmente, uma infinidade de tratamentos de superfícies tem sido aplicada aos implantes de titânio. Esses tratamentos envolvem desde tratamentos puramente mecânicos que visam o aumento da rugosidade superficial até tratamentos químicos que envolvem mudanças estruturais na camada de óxido. Segundo Kawahara (1995) os três principais métodos de modificação das superfícies dos implantes são:

1. Aplicação de recobrimentos por diferentes métodos: os recobrimentos são feitos para a criação de uma superfície bioativa, geralmente se utiliza hidroxiapatita.

2. Tratamentos químicos com ácidos, anodização ou implantação iônica: os tratamentos químicos têm por objetivos principais a limpeza da superfície, criação de rugosidade e ativação da superfície através da alteração estrutural da camada de óxido.

3. Tratamento mecânico por jateamento ou usinagem: neste tratamento, o aumento da rugosidade das superfícies é feito geralmente como o jateamento com partículas duras de óxido. Os óxidos mais usados são óxido de titânio, alumínio ou silício.

Nas duas últimas décadas tem-se observado um grande avanço em técnicas para modificação da superfície (KOTHA et al., 2006; ACAR et al., 2007; DEYNEKA et al., 2007). Essas técnicas fazem uso de plasmas, lasers, feixes de íons e feixes de elétrons como fontes energéticas para alteração estrutural e/ou composicional da superfície, ou ainda para a deposição de filmes. Processos estes, atualmente, denominados como "funcionalização", "reestruturação química", "compatibilização superficial" ou simplesmente "ativação" de superfícies orgânicas e inorgânicas, que objetivam torná-las quimicamente ativas para interagirem com demais compostos presentes em fase aquosa ou gasosa (ASSIS, 2001). 
Dos métodos citados acima, o mais utilizado comercialmente é processamento a plasma em spray ("plasma spraying"). O plasma é o estado de manutenção de um gás parcialmente ionizado, gerando espécies e radicais que são acelerados e acabam por interagir com a superfície da amostra. O tratamento por plasma pode ser empregado para promover a oxidação ou a polarização superficial de forma homogênea. Um aspecto importante é que topografias irregulares podem ser tratadas de forma contínua com a admissão de grupos funcionais de interesse. Superfícies cerâmicas, metálicas ou poliméricas podem ter sua atividade ou molhabilidade total ou parcialmente alterada pela implantação de grupos polares afins (ASSIS, 2001).

O termo plasma se aplica a um gás contendo espécies neutras e eletricamente carregadas como elétrons, íons positivos, átomos e moléculas. As cargas livres no plasma podem mover-se em resposta a qualquer campo elétrico e neutralizá-lo. Se uma carga qualquer é inserida em um plasma ou um campo é imposto, produz um potencial $V_{0}$ às cargas livres, compostas de elétrons, que se moverão formando uma blindagem elétrica (ALVES JR. et al., 2006).

O grupo do Laboratório de Processamento de materiais a Plasma (LabPlasma) desenvolveram o método de bombardeamento por íons de argônio em cátodo planar (ALVES JR. et al., 2006), o qual diferentemente das outras técnicas de modificação a plasma, permite o controle da rugosidade obtida através do aumento ou diminuição da energia de bombardeamento e/ou número de íons bombardeantes, produzindo uma textura uniforme. Dessa forma, é possível alterar sistematicamente a topografia de superfícies sem alterações químicas da mesma. Por outro lado, quando modificações químicas se fazem necessárias, pode-se substituir os íons de argônio por outro elemento, por exemplo, nitrogênio, tendo assim uma modificação química e topográfica da superfície. 


\subsection{PROPRIEDADES DA SUPERFÍCIE E A OSSEOINTEGRAÇÃO}

Focalizando-se especificamente a osseointegração de implantes, pôde-se perceber nas duas últimas décadas um interesse constante no estudo das variáveis que influenciam o grau de deposição óssea nas superfícies implantares.

Desde 1985, Thomas e Cook investigaram inúmeras variáveis e demonstraram que dentre 12 parâmetros estudados em fêmures de cães, somente as características das superfícies desempenhavam um papel relevante na osseointegração dos implantes. As características analisadas envolveram módulo elástico dos materiais, textura das superfícies, assim como suas composições.

À medida que algumas publicações passaram a acusar fracassos significativos dos implantes com superfícies lisas, incrementou-se a pesquisa e o desenvolvimento das superfícies texturizadas. Estas, atualmente, são conhecidas por acelerar a fase de cicatrização inicial, devido à maior adsorção de proteínas, acúmulo e ativação de plaquetas e retenção de fibras, promovendo aposição óssea em menores períodos de tempo (KASEMO, 2002).

Em estudo histomorfométrico em cobaias, Buser et al. (1991) demonstraram que os implantes com superfícies rugosas implantados nas tíbias dos animais apresentaram maiores taxas de contato osso-implante. Considerando o papel preponderante que as características da superfície do implante têm na resposta reparacional, Baier e Meyer (1988) classificaram-nas em três categorias: textura (ou rugosidade), carga (ou potencial elétrico) e química (normalmente descritos em valores de energia de superfície, p. ex.: tensão superficial). Concluíram que o eventual grau de integração correlaciona-se positivamente com a deposição daquilo que nomearam de filme condicionador glicoprotéico que, por sua vez, depende de dois fatores: da textura, com sua propriedade de embricamento celular e da energia de superfície, com sua propriedade de adsorção molecular (wettability). A adsorsão protéica ocorre rapidamente, com a formação de uma camada de 2 a $5 \mathrm{~nm}$, no primeiro minuto após o contato com sangue. Como regra geral, as células não aderem diretamente às superfícies dos materiais e sim à camada glicoprotéica 
extracelular que está adsorvida na superfície do implante. Dentre as várias macromoléculas capazes de promover aderência celular, as mais estudadas são: integrinas, fibronectina, laminina, epibolina, epinectina, osteopontina, colágeno e vitronectina.

Bowers et al. (1992) utilizaram um perfilômetro para avaliar se superfícies implantares lisas ou rugosas, com morfologia regular ou irregular, podem ser consistentemente produzidas com métodos convencionais de fabricação. Testaram in vitro as respostas celulares de fibroblastos a estas superfícies de titânio e averiguaram que níveis altamente significativos de adesão celular estavam associados às superfícies rugosas irregulares jateadas com partículas duras de óxido.

Movidos por semelhante curiosidade, Cooper et al. (1999) optaram por um estudo comparativo entre as superfícies implantares de titânio polidas, aspergidas com plasma de titânio (TPS) e as jateadas com o óxido de titânio. Cultura de células osteoblásticas fetais bovinas com marcadores imunológicos foram empregadas para a investigação da eventual formação de matriz óssea mineralizada nas diferentes superfícies. Os diferentes estágios da formação de matriz foram avaliados através da observação dos marcadores em microscópio de luz, já a detecção de mineralização dentro da matriz foi possível graças ao corante de Von Kossa. Puderam constatar que as TPS apresentaram um padrão único de formação de matriz quando comparadas às outras duas. Com o emprego de microscopia de varredura, notaram que cada superfície acumulou uma quantidade distinta de matéria orgânica e inorgânica na formação de matriz óssea. Essas evidências sugeriram que respostas celulares distintas ocorreram dependentes das propriedades físico-químicas inerentes ou produzidas pelo condicionamento das superfícies.

Em 1989, Michaels e cols. avaliaram a adesão celular (CA) sobre superfícies de Ti com vários graus de rugosidade, preparadas da seguinte maneira: polidas com pasta diamantada de $1 \mu \mathrm{m}$ (superfície lisa) e outras lixadas com papel de sílica granulação $600 \mu \mathrm{m}$ ou jateadas (superfície rugosa). Fibroblastos de ligamento periodontal humano ou osteoblastos da calvária de ratos em meio apropriado foram incubados sobre várias superfícies de Ti por mais de 2 horas. O número de células que não aderiram foi quantificado e a porcentagem de células aderidas foi então calculada. A 
superfície de plástico dos frascos de cultura foi usada como controle. Após 15 minutos a $\mathrm{CA}$ e os fibroblastos do ligamento periodontal apresentaram índices maiores sobre as superfícies lisas $(41 \%)$ e menores nas superfícies rugosas $(28 \%)$. Com 2 horas, a CA foi aproximadamente a mesma para as duas superfícies e o controle (80\%). Já para os osteoblastos a resposta foi diferente. Inicialmente, aos 15 minutos, a CA foi à mesma para superfícies lisas ou rugosas (30\%). Contudo após 2 horas, a CA para superfícies rugosas $(63 \%)$ e para o controle $(64 \%)$ foi significativamente maior do que sobre a superfície lisa. Este trabalho sugeriu que diferentes células do tecido conjuntivo apresentaram respostas variadas à rugosidade superficial, a qual pode, portanto, influenciar a resposta biológica aos implantes.

Rosa e Belotti (2003) estudaram o efeito da rugosidade de superfície de TiCP

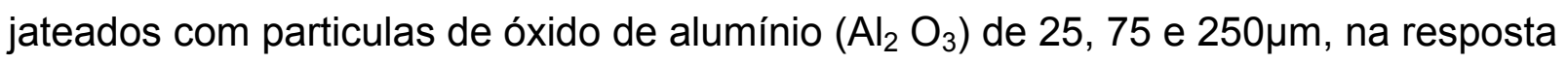
de osteoblastos humanos. Foram utilizados discos de titânio de $12 \mathrm{~mm}$ de diâmetro por $4 \mathrm{~mm}$ de altura. $O$ jateamento originou superfícies com Ra (rugosidade média) de 1,69; 1,83 e 1,91 $\mu \mathrm{m}$ respectivamente, demonstrando uma clara relação entre rugosidade e tamanho da partícula de $\mathrm{Al}_{2} \mathrm{O}_{3}$. A adesão celular e a deposição de nódulo mineralizado não foram afetadas pelo tipo de superfície, enquanto a proliferação e quantidade de proteínas foram dependentes da rugosidade da superfície. Os resultados obtidos sugerem que superfícies mais rugosas interferem em parâmetros celulares tais como aumento na atividade fosfatase alcalina e redução na proliferação celular.

Muhonen et al. (2007) investigaram a influência da espessura desta camada de óxido na superfície de $\mathrm{Ti}$ nitretado sobre a sobrevivência e adesão de osteoblastos (ROS-17/2,8). Os resultados claramente mostraram uma correlação linear entre a espessura da camada de óxido e a adesão celular.

$\mathrm{Na}$ busca por uma superfície de $\mathrm{Ti}$ biomimética, Chiesa et al. (2007) desenvolveram uma nova superfície TiCP, tratada primeiramente eletroquimicamente por um dispositivo anódico de faísca (ASD), seguida por um dispositivo anódico alcalino (ATT). Avaliaram a biocompatibilidade deste novo biomaterial por meio de ensaios in vitro utilizando células precursoras de osteoblastos e ensaios in vivo por meio da implantação de parafusos tratados no fêmur de ovelhas e retirada após 4, 8 e 12 semanas para posterior análises histomorfométricas. Os resultados dos testes in 
vitro e in vivo indicaram que o novo processo de tratamento aumentou significativamente a taxa de osseointegração do titânio.

Ismail et al. (2006) comparam os efeitos de diferentes topografias do TiCP e do carbono (diamond-like carbon - DLC) sobre o crescimento e adesão de osteoblastos. Os resultados de seu trabalho demonstraram que TiCP possuía uma superfície mais hidrofílica que o DLC, que favoreceu a adesão e proliferação celular. Em relação à topografia das superfícies de TiCP, verificaram que aquelas com presença de maiores sulcos apresentaram uma viabilidade celular significativamente maior. Entretanto a adesão celular foi maior nas superfícies com sulcos menores. Assim, concluíram que a amplitude de sua topografia assim como a rugosidade influenciam na reposta biológica.

Brama et al. (2007) avaliaram a resposta biológica in vitro e in vivo de substratos de Ti tratados com um dispositivo de laser pulsátil (PLD), sendo este uma tecnologia para obter superfícies de Ti cobertas com carbono (TiC). Houve um aumento da expressão dos genes relacionados com a diferenciação de osteblastos (fosfatase alcalina, pró-colágeno tipo I, ostecalcina e proteína morfogenética óssea-BMP-4) nas superfícies tratadas, mensuradas por PCR em tempo real. Os experimentos in vivo demonstraram maior densidade óssea maior em implantes TiC após 2 e 4 semanas em ovelhas quando comparado com os implantes não tratados.

Kim et al. (2006) avaliaram diferentes níveis de rugosidade de superfícies de Ti. Os discos de TiCP receberam dois tratamentos: jateados ou submetidos a descarga elétrica para produzir superfícies texturizadas. O comportamento dos osteblastos-MG63 foram comparados quanto ao número, atividade da fosfatase alcalina, expressão gênica do Runx2 e produção de colágeno. As superfícies jateadas demonstraram características de rugosidade mais homogênea e taxas de Ra significativamente maiores. Nestas amostras também foi observado um aumento significativo na produção de colágeno, expressão de Runnx2 e na atividade da fosfatase alcalina. Entretanto, com o aumento na rugosidade houve diminuição na taxa de proliferação. Os autores, concluíram que Ra entre $1-3 \mu \mathrm{m}$ contribuiu efetivamente para diferenciação osteogênica e proliferação. 
Giordano et al. (2006) investigaram a resposta biológica de três diferentes superfícies de $\mathrm{Ti}$. Algumas receberam tratamento químico outras jateadas e a terceira superfície foi uma combinação de ambos. A análise das superfícies revelou que possuíam propriedades físico-químicas diferentes, entretanto não houve variação significativa na atividade de fosfatase alcalina, taxas de crescimento e adesão celular.

Como relatado, trabalhos recentes mostraram que a rugosidade superficial do implante favorece a adesão de osteoblastos, sua diferenciação e a produção de matriz extracelular, resultando em maior contato osso-implante, contato este que foi alcançado mais rapidamente; e resulta em maiores forças necessárias para removêlos por torque. Essas características das superfícies rugosas poderão reduzir o tempo necessário para a colocação dos implantes em função, possibilidade que já vem sendo testada por estudos recentes. Também poderão, melhorar o prognóstico para implantes colocados em áreas com tecido ósseo menos denso, ou ainda, em áreas de reconstrução óssea.

Contudo é notória é a dificuldade de analisar as publicações em geral, para se estabelecer parâmetros comparativos entre os estudos, devido à falta de caracterização das superfícies testadas e ao desconhecimento das reações celulares e teciduais às diversas modificações da superfície possíveis. É importante esclarecer que as superfícies rugosas não são iguais entre si e, por conseqüência novas superfícies rugosas não responderão necessariamente como aquelas que já têm comprovada eficiência. 
Material e Métodos 


\section{MATERIAL E MÉTODOS}

No presente trabalho foi produzida uma nova superfície de Ti pelo método de processamento a plasma em cátodo planar desenvolvido no Laboratório de Processamento de Matérias a Plasma da UFRN. Em seguida, essa superfície foi caracterizada quanto a sua molhabilidade, rugosidade e topografia. Foram cultivadas células de ovário de Hamster Chinês (CHO) e células pré-osteoblásticas (MC3T3-E1) para avaliação da genotoxicidade e resposta biológica das células sobre a superfície produzida, respectivamente (Figura 1).

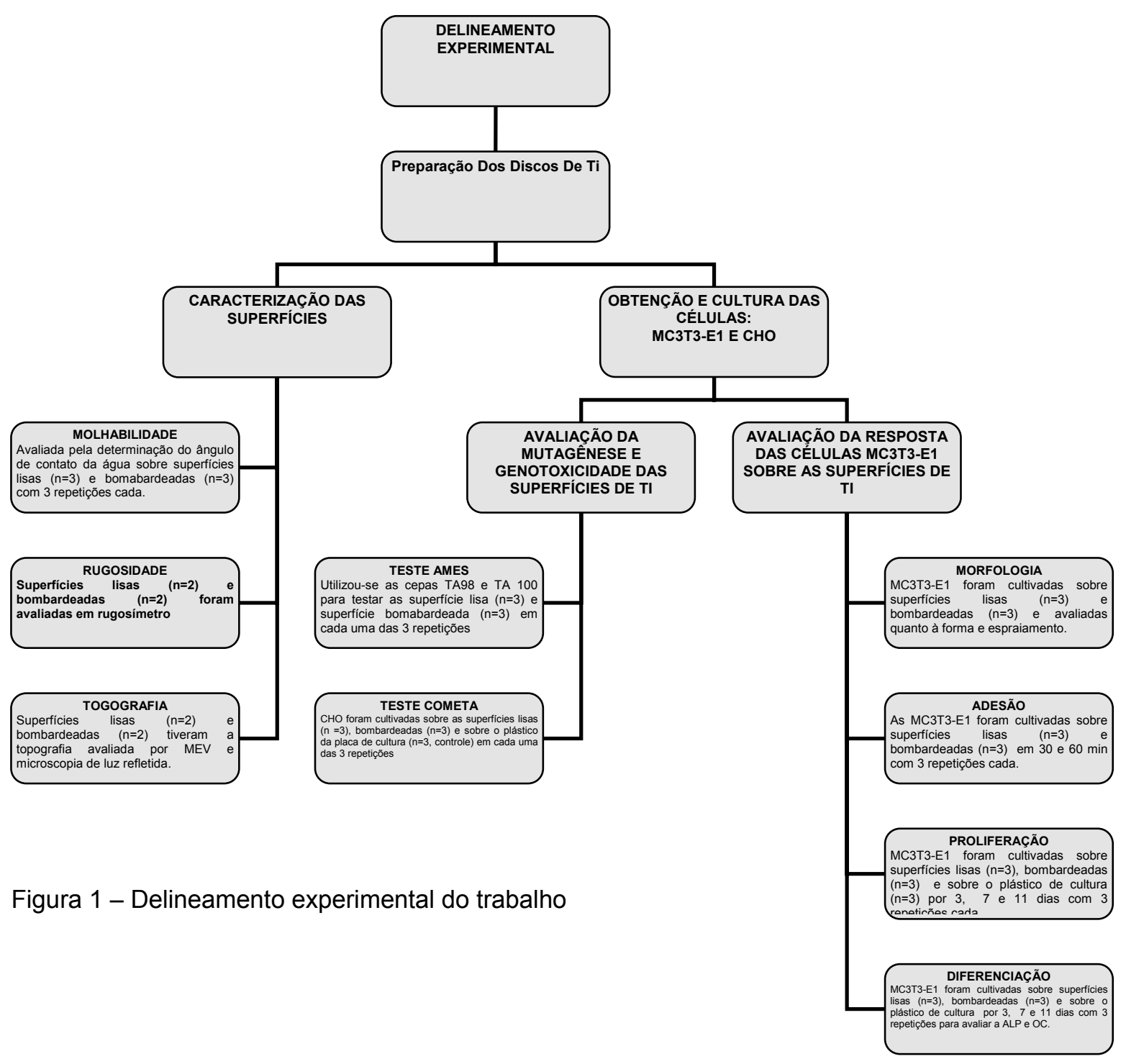




\subsection{PREPARAÇÃO DOS DISCOS DE TITÂNIO}

Neste trabalho foram utilizados discos de TiCP, medindo $9 \mathrm{~mm}$ de diâmetro e $3 \mathrm{~mm}$ de espessura. Os discos foram lixados com lixas de carbeto de silício de granulometria $80,150,220,360,500,600,1200$ e 2000 MESH e o polimento executado com uma solução constituída de $60 \mathrm{ml}$ de OP-S (solução de sílica coloidal) e $40 \mathrm{ml}$ de $\mathrm{H}_{2} \mathrm{O}_{2}$ por 30 minutos. Após o polimento, as amostras foram submetidas a tratamento em plasma para modificação da superfície de acordo com metodologia empregada por Alves Jr. et al. (2006) no Laboratório de Processamento de Materiais por Plasma da Universidade Federal do Rio Grande do Norte. Foram utilizados os seguintes estados de superfície: polida (sem tratamento) e bombardeada. As amostras com superfície bombardeada foram obtidas através do tratamento em descarga por cátodo planar em atmosfera a vácuo e argônio. Devido ao bombardeamento de íons de argônio sobre a superfície polida do Ti foram criados defeitos, os quais contribuíram para o surgimento de reentrâncias e saliências.

$\mathrm{O}$ aparato experimental utilizado para o tratamento em plasma das amostras de Ti consistiu de uma câmara cilíndrica de 200 × 300 mm (diâmetro x altura), hermeticamente fechada contendo um ânodo (terra) na parte superior e uma base catodicamente polarizada com potencial entre -400 e $-800 \mathrm{~V}$. Sobre essa base foi posicionada a peça a ser tratada. A distância entre a superfície da amostra e a tampa superior, aqui denominada distância entre cátodos $\left(\mathrm{d}_{\mathrm{cc}}\right)$, foi fixada em $9 \mathrm{~mm}$. Todas as amostras foram tratadas sob pressão de $3 \mathrm{mbar}$, a $600^{\circ} \mathrm{C}$ durante $2 \mathrm{~h}$ (Figuras $2 \mathrm{e}$ 3). 


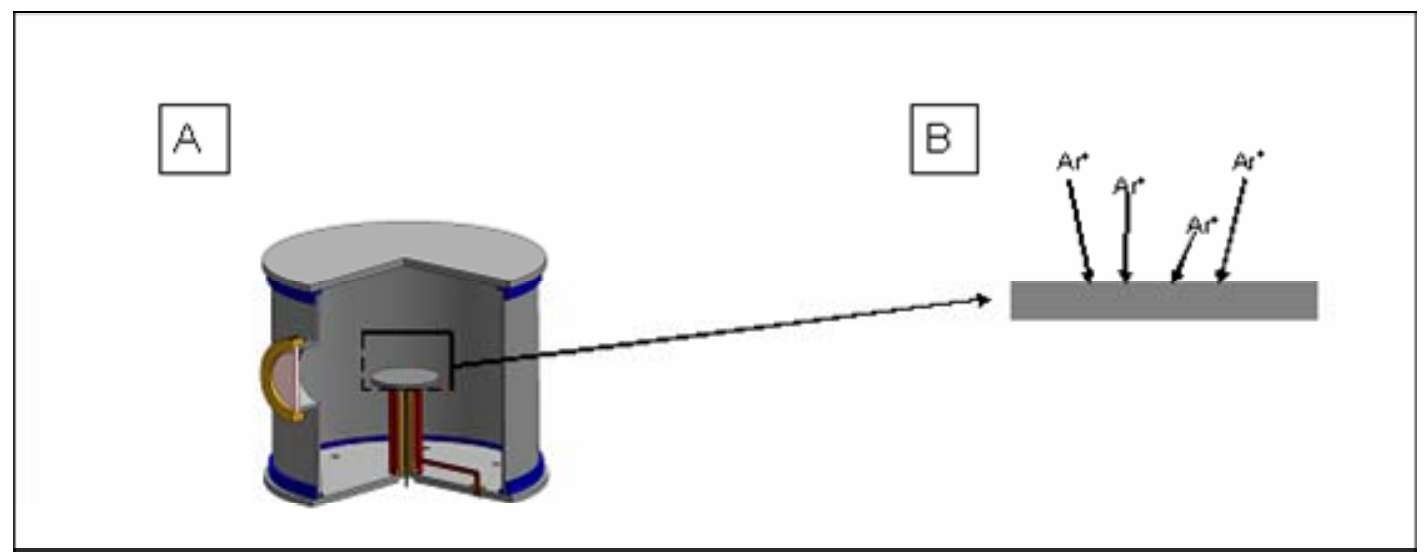

(Fonte: ALVES JR et al., 2006. Imagem cedida pelo autor)

Figura 2 - Esquema representativo do bombardeamento de íons de argônio das superfícies de titânio. A - Câmara hermeticamente fechada; B - Cátodo planar
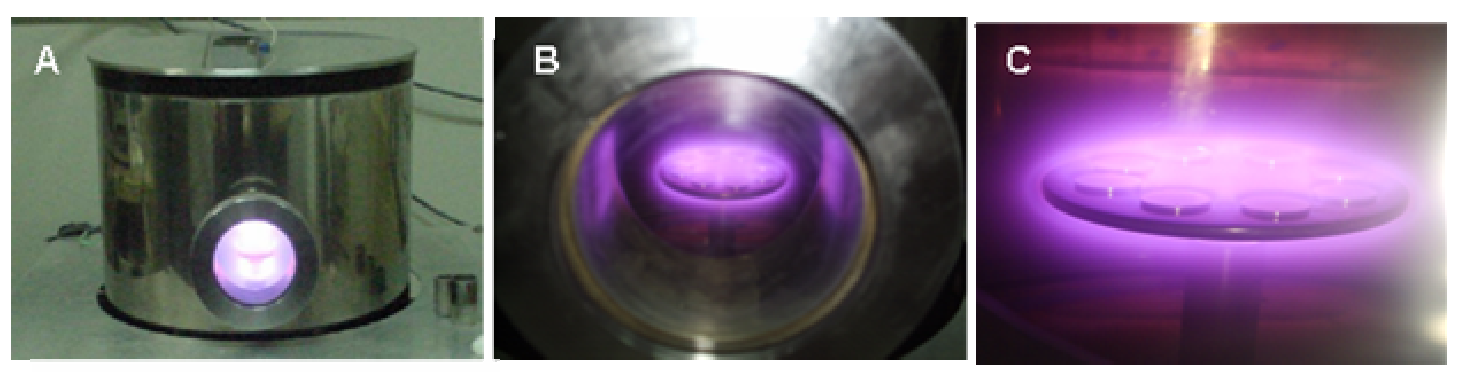

Figura 3 - Aparato experimental do Laboratório de Processamento de Matérias a plasma utilizado para tratamento das superfícies de Ti. A - Câmara hermeticamente fechada. B- Cátodo planar. C- Discos de Ti dispostos sobre o cátodo recebendo o tratamento

Ambos os discos, polidos ou bombardeados com argônio foram colocados em solução $0,5 \%$ de DEIV 3E (detergente enzimático) em água bidestilada e submetidos a tratamento em ultra-som por $10 \mathrm{~min}$. Após duas lavagens, os discos foram lavados em etanol absoluto e posteriormente em água bidestilada (duas vezes). Em cada etapa os discos foram submetidos a ultra-som por $10 \mathrm{~min}$. Depois de secos, os discos foram esterilizados em plasma de peróxido de hidrogênio. Para os 
experimentos com cultura de célula, os discos também foram autoclavados a $120^{\circ} \mathrm{C}$ por $20 \mathrm{~min}$.

\subsection{CARACTERIZAÇÃO DA SUPERFÍCIE}

\subsubsection{Molhabilidade}

A técnica utilizada para caracterizar a molhabilidade das amostras foi a de determinação do ângulo de contato estático realizada em 6 discos de cada superfície (bombardeada e lisa), conforme descrito por Sá (2006): com o auxílio de uma pipeta graduada, $20 \mu \mathrm{l}$ da solução foi gotejada sobre cada disco utilizando-se um aparato de molhabilidade desenvolvido no Labplasma (Figura 4).

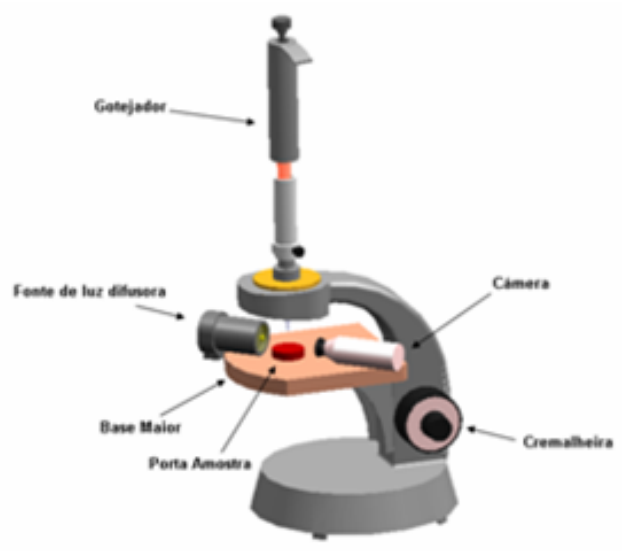

Fonte: SÁ, 2006. Imagem cedida pelo autor.

Figura 4 - Esquema representativo do aparato utilizado para determinar a molhabilidade das superfícies de $\mathrm{Ti}$ 
Fotografias foram tiradas 1 segundo e 15 segundos após o gotejamento, utilizando-se um programa de captação de imagens Pinnacle Studio 9.0. O teste de molhabilidade foi analisado por software desenvolvido no mesmo laboratório, no qual se mede o ângulo de contato entre a superfície sólida (disco) e o plano tangencial à superfície líquida (água) (Figura 5).

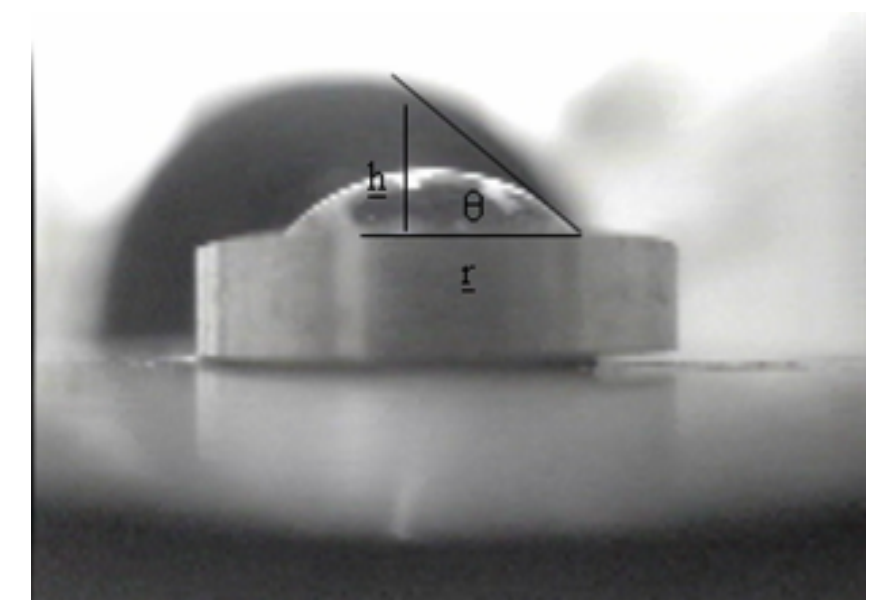

Figura 5 - Fotografia da gota de água sobre o disco de $\mathrm{Ti}$ capturada pela câmera acoplada ao aparato de determinação da molhabilidade. Observar as retas traçadas, uma paralela a superfície do disco e a outra tangente a gota, utilizadas para determinar o ângulo de contato $\underline{\theta}$

Baseado na literatura existente buscou-se desenvolver uma maneira onde a medida do ângulo de contato fosse obtida a partir de uma relação matemática [1], tendo como princípio o esquema mostrado na figura 6.

$$
\theta=\sin ^{-1}\left[2 r h / r^{2}+h^{2}\right][1]
$$

Onde $\theta$ é um ângulo de contato a ser medido; $h$ corresponde à medida da distância entre o centro da gota e seu ponto mais alto e $r=a$ medida da tangente da superfície metálica até o cruzamento com eixo $\mathrm{h}$. 


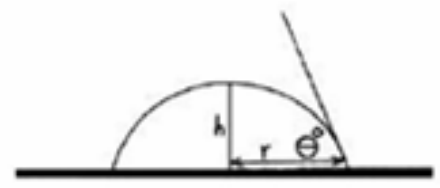

Fonte: SÁ, 2006

Figura 6 - Esquema do ângulo de contato

\subsubsection{Rugosidade}

Para análise da rugosidade foi mensurado o parâmetro rugosidade média (Ra), o qual representa a média aritmética do perfil de rugosidade, obtido a partir dos valores absolutos dos pontos máximos e mínimos de altura e profundidade em relação à linha média da superfície metálica. O parâmetro rugosidade $(\mathrm{Ra})$ foi avaliado utilizando um rugosímentro modelo Robson Taylor Surtronic 3 (Taylor Hobson Ltd, Leicester, England) e as medidas foram tomadas em toda a superfície dos discos em duas direções conforme metodologia proposta por Silva et al. (2006).

\subsubsection{Topografia}

A topografia da superfície dos discos foi avaliada utilizando microscopia eletrônica de varredura (MEV). Para tanto, os discos foram montados em suportes de alumínio, receberam cobertura de ouro com aproximadamente $20 \mathrm{~nm}$ de espessura e foram observados em microscópio eletrônico de varredura (MEV-SSX 550 Superscan, Japão). As peças foram processadas no Laboratório de Microscopia Eletrônica do Centro de Tecnologia de Gás (CTgás, Natal, RN) e no Setor de Anatomia do Departamento de Cirurgia da Faculdade de Medicina Veterinária - USP. 


\subsection{OBTENÇÃO E CULTURA DAS CÉLULAS}

Cultura de células pré-osteoblásticas foram estabelecidas para realização posterior dos testes de morfologia, adesão, proliferação e diferenciação destas nas superfícies de Ti. As células de ovário de hamster chinês $(\mathrm{CHO})$ foram cultivadas para utilização posterior nos testes de mutagenicidade.

\subsubsection{Cultura das células pré-osteoblásticas}

As células pré-osteblásticas de camundongo linhagem MC3T3-E1 subclone 14, utilizadas neste trabalho, foram cedidas pela Profa. Carmem Veríssimo do Departamento de Bioquímica da Universidade de Campinas (UNICAMP). As células foram cultivadas em meio essencial mínimo (a-MEM; Cultilab, SP, Brasil) suplementado com $10 \%$ de soro fetal bovino (SFB, Cultilab, SP, Brasil), $100 \mathrm{Ul} / \mathrm{ml}$ de penicilina e $100 \mu \mathrm{g}$ de estreptomicina (Cultilab, SP, Brasil). As células foram incubadas a $37^{\circ} \mathrm{C}$ em atmosfera úmida com $5 \%$ de $\mathrm{CO}_{2}$, e trocas do meio de cultura ocorreram a cada $48 \mathrm{~h}$.

\subsubsection{Cultura das células de ovário de hamster chinês (CHO)}

As células de ovário de hamster chinês $(\mathrm{CHO})$ linhagem $\mathrm{K} 1$ foram cultivadas em meio modificado de Eagle com alta concentração de glicose (DMEM, high glucose; Sigma, USA) suplementados com 10\% de SFB (Cultilab, SP, Brasil), 100 $\mathrm{Ul} / \mathrm{ml}$ de penicilina e $100 \mu \mathrm{g}$ de estreptomicina (Cultilab, SP, Brasil). As células foram incubadas a $37^{\circ} \mathrm{C}$ em atmosfera úmida com $5 \%$ de $\mathrm{CO}_{2}$, e trocas do meio de cultura ocorreram a cada $48 \mathrm{~h}$. 


\subsection{GENOTOXICIDADE E MUTAGENICIDADE DO BOMBARDEAMENTO DO Ti COM ÍONS DE ARGÔNIO}

Para avaliar o potencial genotóxico e mutagênico do Ti puro e do tratamento de plasma empregado na superfície foram realizados teste do cometa e teste de Ames.

\subsubsection{Teste cometa}

O teste Cometa consiste de um gel de eletroforese de células individualizadas para verificar se ocorreram quebras no DNA das células que tiveram contato prévio com o composto testado. Neste teste, foram cultivadas $5 \times 10^{3}$ células $\mathrm{CHO}$ sobre disco de Ti e o plástico da placa de cultura (controle), no total de 4 discos bombardeados, 4 lisos e 4 poços controle. $O$ tempo de contato entre as células e o biomaterial avaliado foi de 4 dias. Após a tripsinização, as células foram lavadas com PBS, posteriormente suspensas em $75 \mu \mathrm{l}$ de agarose de baixa fusão fundida, a qual foi aplicada sobre uma lâmina de microscópio, previamente revestida com agarose. Após a solidificação da agarose que contém as células, uma segunda camada isenta de células é colocada sobre a lâmina. Para liberar os núcleos foi feita a lise das células, através da incubação das lâminas durante $16 \mathrm{~h}$ com solução de extração (5 $\mathrm{ml}$ de $2.5 \mathrm{M} \mathrm{NaCl}, 100 \mathrm{mM}$ EDTA, $10 \mathrm{mM}$ Tris- $\mathrm{HCl}$, pH 10, 1\% N-laurylsarcosine, $1 \%$ TritonTM X-100 e 10\% DMSO). Posteriormente, as lâminas foram incubadas em solução de eletroforese com tampão alcalina (300mM Na OH, $1 \mathrm{mM}$ EDTA, pH 12,5) facilitando assim a denaturação e desenovelamento do DNA, promovendo o aparecimento das possíveis quebras na fita do DNA. As lâminas foram então submetidas à eletroforese, na qual os fragmentos de DNA relaxados e/ou quebrados migraram de um pólo a outro. Após a neutralização por lavagem com uma solução de $0.4 \mathrm{M}$ Tris- $\mathrm{HCl}(\mathrm{pH} 7,5)$, a lâmina foi corada com brometo de etídio $(20 \mathrm{mg} / \mathrm{ml})$ por $30 \mathrm{~s}$. As lâminas foram analisadas em microscópio com objetiva a 400X e com grau de excitação de fluorescência de $590 \mathrm{~nm}$. 
Este procedimento permitiu visualizar quebras cromossômicas, indicativo de danos no DNA, induzidas pelo tratamento. Posteriormente foi realizada uma eletroforese em tampão alcalina para se observar a marcação deste material com brometo de etídio. A observação das condições do material genético testado foi realizada por meio de microscopia de fluorescência. Quando o DNA é danificado, os menores fragmentos deste migram antecedendo o deslocamento das moléculas intactas, o que proporciona um rastro, cuja imagem se assemelha a um cometa. Por este motivo este teste foi denominado de teste cometa. A qualificação da extensão dos danos foi feita pelo tamanho do rastro observado (SINGH et al., 1988).

\subsubsection{Teste Ames}

O teste de Ames, desenvolvido por Ames et al. (1973) e modificado por Maron e Ames (1983), avalia o potencial de um certo composto químico ou misturas complexas de induzirem mutações no genoma de linhagens bacterianas mutantes (auxotróficas) revertendo-as para o estado selvagem (prototrófico).

Este teste utiliza as linhagens de Salmonella typhimurium, que apresentam mutações pontuais específicas de vários tipos como transições, transversões e modificação do quadro de leitura, de modo que o evento mutacional de reversão permite estabelecer a freqüência e o tipo de mutação ocorrido. A mutação leva à inativação de uma enzima da via biossintetizante da histidina (his) impedindo, portanto, seu crescimento em meio desprovido de tal aminoácido. Dessa forma, em meio mínimo, somente conseguirão crescer aquelas colônias que foram capazes de reverter a mutação, passando, portanto, à condição selvagem, ou seja, sendo capazes de sintetizar a histidina (his+).

Essas linhagens apresentam também outras modificações que aumentam a sensibilidade do teste. Entre estas podemos citar: mutação ifa que leva a um aumento da permeabilidade bacteriana por alterar a camada lipopolissacarídica da parede celular e a mutação uvrB tornando-as incapazes de reparar lesões no DNA por excisão de nucleotídeos. (MARON; AMES, 1983). 
As linhagens utilizadas para avaliar o potencial mutagênico do tratamento de superfície foram TA98 e TA100 (GATHEHOUSE et al., 1994; MORTELMANS; ZEIGER, 2000). A linhagem TA98 detecta substâncias que causam mutações por alteração do quadro de leitura revertendo à mutação por deleção de um par de bases GC no gene hisD6610 e TA100. A TA100 detecta compostos que causam mutações por substituição de base e é revertida pela substituição de um par GC por AT no gene hisG46 (LEVIN et al., 1982).

Os discos de $\mathrm{Ti}$ lisos e bombardeados foram testadas utilizando a metodologia proposta por Russell et al. (1998) e descrita a seguir. As cepas bacterianas foram amostradas em volume de $100 \mu \mathrm{l}$ para cada disco a ser testado, incluindo o controle, representado por discos de papel filtro. Foram realizados 3 experimentos utilizando 3 discos de Ti liso, 3 bombardeados e 3 de papel filtro (controle), em cada repetição

As superfícies ficaram em contato com as cepas por 90 minutos a $37^{\circ} \mathrm{C}$, posteriormente foram distribuídas em placas contendo meio-ágar mínimo. As placas foram incubadas a $37^{\circ} \mathrm{C}$ por $66 \mathrm{~h}$. Os resultados foram expressos pela razão de mutagenicidade (RM), para cada uma das amostras testadas. Para realização destes cálculos foi utilizado o programa SALANAL, desenvolvido por Dr. Lawrence Myers, USA.

\subsection{MORFOLOGIA DOS PRÉ-OSTEBLASTOS SOBRE AS SUPERFÍCIES DE Ti}

Para avaliar influência das superfícies de Ti sobre a morfologia dos préosteoblastos realizou-se três experimento onde foram adicionadas $5 \times 10^{3}$ destas células sobre os 6 discos de Ti: lisos e bombardeados ( $n=3$ de cada superfície para cada tempo por experimento) e cultivadas por 3, 7 e 11 dias, utilizando meio essencial mínimo (a-MEM; Cultilab, SP, Brasil) suplementado com $10 \%$ de soro fetal bovino (SFB, Cultilab, SP, Brasil), $100 \mathrm{Ul} / \mathrm{ml}$ de penicilina e $100 \mu \mathrm{g}$ de estreptomicina (Cultilab, SP, Brasil). 
Após os tempos estabelecidos, os discos foram retirados da cultura, fixados e processados conforme descrito abaixo para análises em microscópio de luz refletida, eletrônico de varredura e de força atômica.

\subsubsection{Microscopia óptica de luz refletida}

Três discos dos dias 3,7 e 11 de cultivo das células pré-osteblásticas sobre cada superfície foram fixados em glutaraldeído 2,5\% em Tampão fosfato $\mathrm{pH} 7,4$ (PBS). Em seguida, a morfologia das células e o biofilme produzido por elas foram visualizados em microscópio de luz refletida (Olympus BX-600M) com câmera acoplada (Media Cybernetics LC-Capture).

\subsubsection{Microscopia eletrônica de varredura (MEV) e proliferação celular}

As células cultivadas sobre as superfícies após 3, 7 e 11 dias foram lavadas duas vezes em PBS, para remoção das células não-aderentes e sujidades depois fixadas em 2,5\% de glutaraldeído em PBS pH 7,2; desidratadas em concentrações crescentes de etanol; secas em ponto-crítico $\mathrm{CO}_{2}$ (Emscope CPD 750, Elexience, Paris, França), revestidas em ouro e visualizadas no microscópio eletrônico de varredura (MEV-SSX 550 superscan, Japão).

A análise das imagens pela microscopia eletrônica de varredura permitiu avaliar a influência da superfície sobre a forma e o grau de espraiamento das células pré-osteblásticas ainda em uma fase inicial por meio de um fator forma (FF) obtido em função da área e perímetro das células, conforme a seguinte fórmula FF = (área/ perímetro $\left.{ }^{2}\right) \times 4 \pi$ proposto por Shah et al. (1999).

Após 3 dias de cultivo, de cada disco foram avaliadas 100 células, por meio de imagens obtidas em Microscópio eletrônico de varredura (MEV) sob aumento de 200x. As eletrofotomicrografias foram submetidas ao programa analisador de 
imagens (Image-pro plus ${ }^{\circledR}$ ) para o cálculo da área e perímetro celular, em seguida esses dados foram utilizados para o cálculo do FF médio para cada superfície.

\subsubsection{Microscopia de força atômica (AFM)}

As células pré-osteoblásticas foram cultivadas sobre discos de Ti durante 3, 7 e 11 dias. Após os períodos de incubação propostos, as amostras foram 2 vezes lavadas em PBS, para remoção das células não-aderentes e sujidades; fixadas em 2,5\% de glutaraldeído em PBS pH 7,2; desidratadas em concentrações crescentes de etanol e visualizadas no microscópio de força atômica (AFM Digital instruments Santa Bárbara, Califórnia, EUA) no Departamento de Física da Universidade Federal do Ceará (UFC).

A Microscopia de força atômica foi utilizada para avaliar, em uma escala submicrométrica, a forma, os contatos focais de adesão, rugosidade e produção de matriz das células aderidas às superfícies de Ti.

\subsection{PROLIFERAÇÃO DOS PRÉ-OSTEOBLASTOS SOBRE AS SUPERFÍCIES DE Ti}

A proliferação das células pré-osteoblásticas sobre os discos de $\mathrm{Ti}$ foi avaliada conforme metodologia proposta por Faghihi et al. (2006), a saber: 5000 células/ $\mathrm{cm}^{2}$ foram adicionados sobre os discos de Ti (superfície lisa e superfície bombardeada) e sobre o plástico de placas de cultura de 24 poços (controle) e retirados da cultura após 3, 7 e 11 dias (sendo 3 repetições para cada superfície e controle por tempo estabelecido). Em seguida, as amostras foram lavadas duas vezes com PBS e tratadas com tripsina-EDTA $0,25 \%$. A viabilidade foi determinada com azul de tripan e para contagem foi usado hemocitômetro (Câmara de Neubauer) conforme fórmula abaixo. 
Total de células $=\mathrm{n}^{\circ}$ de células $/ \mathrm{ml} \times$ volume original da suspensão de células, onde Número de células/ $\mathrm{ml}$ é o quociente da média do $\mathrm{n}^{\circ}$ de células/ $\mathrm{ml}$ quadrante $\mathrm{x}$ fator diluição $\times 10^{4}$

Os valores da proliferação celular de cada tempo estabelecido foram normalizados com o respectivo conteúdo de proteína total obtido após lise celular das mesmas amostras, e expresso como unidades por miligrama de proteína total. O conteúdo de proteína total foi determinado usando o método Bradford (1976). A absorbância do produto da reação foi mensurada em $562 \mathrm{~nm}$ usando Espectrofotômetro (FEMTO, FEMTO industrial e Cia LTDA, Brasil, São Paulo) e a concentração de proteína calculada a partir de uma curva padrão.

Outro método utilizado para avaliar a proliferação destas células sobre os discos de $\mathrm{Ti}$ o programa analisador de imagens (Image-pro plus ${ }^{\circledR}$ ) a partir de imagens provenientes do MEV. De cada amostra foram obtidas imagens de 5 quadrantes tomando como referência o centro (Quandrante 1 - Q1) e percorrendo um raio de $750 \mu \mathrm{m}$ para os cantos superiores e inferiores direito e esquerdo, gerando mais 4 quadrantes (Q2, Q3, Q4 e Q5) conforme esquema na figura 7. Em seguida, as células aderidas dos cinco quadrantes foram quantificadas e os resultados submetidos à análise estatística.

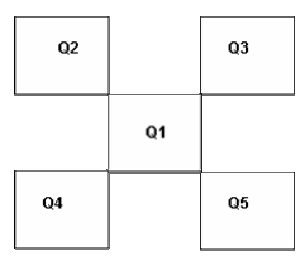

Figura 7- Esquema representativo da captura das imagens dos quadrantes utilizados para avaliar a proliferação das células pré-osteblásticas sobre discos de Ti pelo programa analisador de imagens 


\subsection{ADESÃO DOS PRÉ-OSTEOBLASTOS SOBRE AS SUPERFÍCIES DE Ti}

A taxa de adesão das células foi avaliada seguindo o método proposto por Rocha et al. (2005) conforme descrito a seguir: as células aderidas em ambos os tipos de superfície de Ti foram avaliadas após 30 e 60 minutos de incubação. Os discos foram dispostos em placas de 24 poços e sobre elas adicionados 7500 células $/ \mathrm{cm}^{2}$. Após a incubação, os poços foram lavados duas vezes com PBS e o material foi fixado com metanol PA gelado por $5 \mathrm{~min}$. Posteriormente, o metanol foi aspirado, os poços foram lavados com PBS e as células foram coradas com cristal violeta $0.2 \%$ em etanol $2 \%$. Após cinco minutos, os poços foram lavados cinco vezes com PBS para retirada do excesso de corante e aquele encontrado no interior das células foi removido com uma solução de etanol $50 \%$ e citrato de sódio $0,1 \mathrm{M}$, que promoveu a lise celular e liberação deste corante. A concentração de corante por amostra foi mensurada em leitor de ELISA (Asys- modelo Expert plus, Eugendorf, Áustria) a 550nm.

\subsection{DIFERENCIAÇÃO DOS PRÉ-OSTEBLASTOS SOBRE AS SUPERFÍCIES DE TI}

A diferenciação de pré-osteoblastos em osteblastos foi avaliada por meio da mensuração da atividade da fosfatase alcalina, enzima importante no processo de mineralização do matriz extracelular e pela expressão da osteocalcina, um marcador especifico de osteoblastos.

\subsubsection{Atividade de fosfatase alcalina}

A atividade da fosfatase alcalina (ALP) foi avaliada depois de 3, 7, 11 e 14 dias de cultura das células pré-osteoblásticas sobre as superfíceis de $\mathrm{Ti}$, lisa e bombardeada, e sobre o plástico de placas de cultura de 24 poços. O meio de cultura 
utilizado foi o a-MEM, suplementado de $10 \%$ de SFB, $50 \mu \mathrm{g} / \mathrm{ml}$ de ácido ascórbico e $10 \mathrm{mM} \beta$-glicerofosfato. As trocas de meio foram realizadas a cada $48 \mathrm{~h}$.

Após cada tempo estabelecido, o meio de cultura de cada poço foi coletado e mantido a $-20^{\circ} \mathrm{C}$ até análise da atividade da fosfatase alcalina.

O kit $p$-nitrofenilfosfato ( $p$-nitrophenylphosphatase, Vector laboratories, Burlingame, USA) foi utilizado para determinar a atividade da fosfatase alcalina. Cada reação foi iniciada adicionando-se $15 \mu \mathrm{l}$ da solução de p-nitrofenilfosfato (pNPP) diluído em bicarbonato de sódio $\mathrm{pH} 10$ na proporção de 1:20. A reação foi bloqueada após $60 \mathrm{~min}$ com $1 \mathrm{ml}$ de $\mathrm{NaOH} 0,25 \mathrm{~N}$. A densidade óptica equivalente a quantidade de p-nitrofenol foi obtida por leitor de ELISA (Asys- modelo Expert plus, Eugendorf, Áustria) a $405 \mathrm{~nm}$ para quantificar o conteúdo de p-nitrofenol produzido. Os valores da atividade de ALP foram normalizados com o respectivo conteúdo de proteína total obtido da mesma amostra e expressos em UA/ $\mu \mathrm{g} / \mathrm{mol}$.

\subsubsection{Análise de citometria de fluxo para osteocalcina}

A expressão de osteocalcina nas células pré-osteoblásticas foi avaliada por citometria de fluxo, após 14 dias (tempo necessário para garantir completa diferenciação dos pré-osteoblastos, FAGHIHI et al., 2006) de cultura dessas células sobre as superfícies de $\mathrm{Ti}$, lisa e bombardeada, e sobre o plástico de placas de cultura de 24 poços. O meio de cultura utilizado para induzir a diferenciação dessas células foi o a-MEM, suplementado de $10 \%$ de SFB, $50 \mu \mathrm{g} / \mathrm{ml}$ de ácido ascórbico e $10 \mathrm{mM} \beta$-glicerofosfato. As trocas de meio foram realizadas a cada $48 \mathrm{~h}$.

Após o tempo estabelecido, as células foram lavadas em PBS e tripsinizadas. As células foram incubadas por $60 \mathrm{~min}$ a $4^{\circ} \mathrm{C}$ com $2 \mathrm{mg} / \mathrm{ml}$ de anticorpo contra osteocalcina de camundongo obtido em cabra (sc-18322; Santa Cruz). Decorrido esse tempo, as células foram lavadas em PBS e incubadas com anticorpo conjugado ao fluorcromo texas-red (sc-2783; Santa Cruz) por $30 \mathrm{~min}$ a $4^{\circ} \mathrm{C}$ na concentração de $0,4 \mathrm{mg} / \mathrm{ml}$. Após três lavagens em PBS, as amostras foram fixadas 
em parafolmaldeído $0,5 \%$ até análise no citômetro. Um total de 20.000 eventos foram adquiridos no citômetro de fluxo (FACScan, BD Biosciences, San Jose, USA). Para análise dos dados o software CellQuest Pro 4.0.1 (BD Biosciences, San Jose, USA) foi utilizado e os resultados foram apresentados em unidades arbitrárias de intensidade de fluorescência e média de células positivas fornecidos automaticamente pelo programa estatístico do aparelho.

\subsection{ANÁLISE ESTATÍSTICA}

Os dados referentes à molhabilidade das superfícies, fator forma e adesão das células MC3T3-E1 em função das superfícies de Ti (lisa ou bombardeada) foram avaliados pelo teste $t$ de student, enquanto a genotoxicidade e mutagenicidade das superfícies, bem como influencia dessas superfícies na proliferação, atividade de fosfatase alcalina, expressão de osteocalcina de MC3T3-E1 foram submetidos à análise de variância (ANOVA), seguida do teste Kruskal-Wallis, utilizando o software GraphPad Instat $\AA$ versão 3.5 para Windows. 
Resultados 


\section{RESULTADOS}

Neste capitulo serão apresentados os resultados referentes à caracterização das superfícies produzidas, avaliação da biocompatibilidade e de sua influencia na resposta in vitro de pré-oestoblastos.

\subsection{CARACTERIZAÇÃO DAS SUPERFÍCIES DE TI}

As superfícies lisas e bomabardeadas foram caracterizadas quanto a molhabilidade, rugosidade e topografia.

\subsubsection{Molhabilidade}

Nas amostras bombardeadas houve uma rápida acomodação da gota séssil de água, portanto o tratamento aplicado produziu superfícies com molhabilidade superior em relação às superfícies lisas (Figura 8).
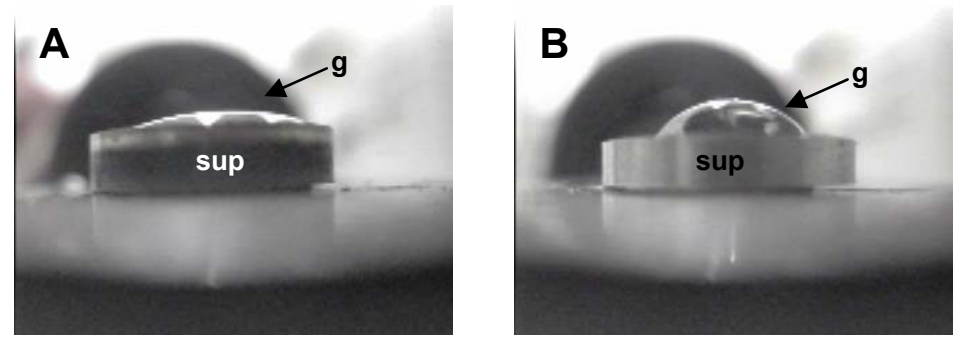

Figura 8 - Imagens da gota de água sobre os discos de Ti capturada pela câmera acoplada ao aparato de determinação da molhabilidade. A- Superfície bombardeada; B- Superfície lisa. Observar imediata acomodação da água na superfície bombardeada. Sup= superfície metálica e g= gota de água 
As medidas dos ângulos de contato foram menores para as superfícies bombardeadas e essas diferenças se mostram altamente significativas $(p<0,0001)$ (Figura 9). Portanto, a superfície tratada com argônio se mostrou mais hidrofílica que a lisa.

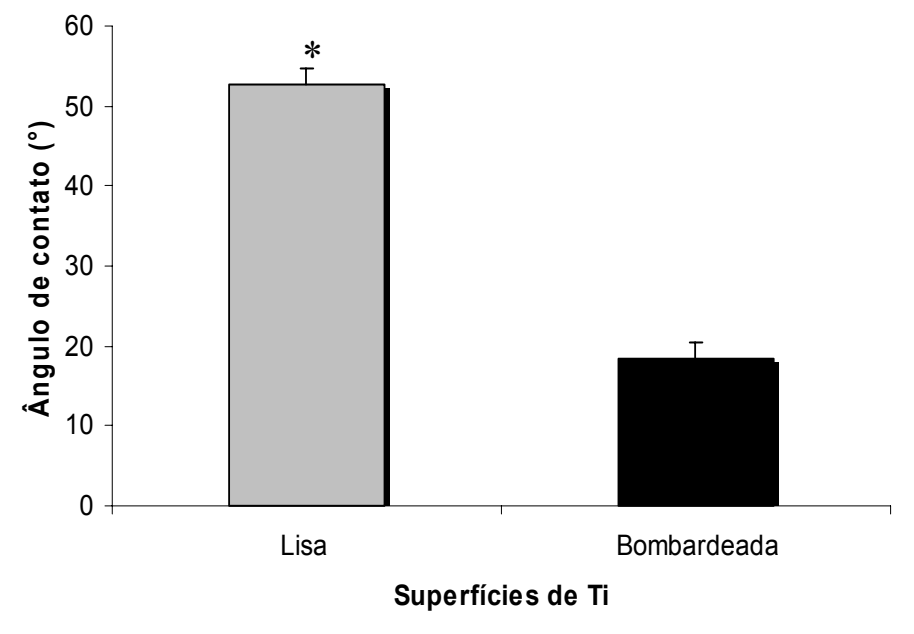

Figura 9 - Medida dos ângulos médios de contato da gota de água e de glicerol nas superfícies de Ti tratada a plasma em atmosfera de argônio (texturizada) e apenas polidas (lisa). *diferença significativa entre os grupos $(p<0.05)$

\subsubsection{Rugosidade}

Constatou-se que o processamento a plasma produziu grandes modificações na superfície dos discos de Ti. Aqueles tratados com plasma em atmosfera de argônio apresentaram uma rugosidade média $(\mathrm{Ra})$ de $0,11 \mu \mathrm{m}$, enquanto para superfícies lisas o Ra foi de 0,027 $\mu \mathrm{m}$ (Figura 10). 


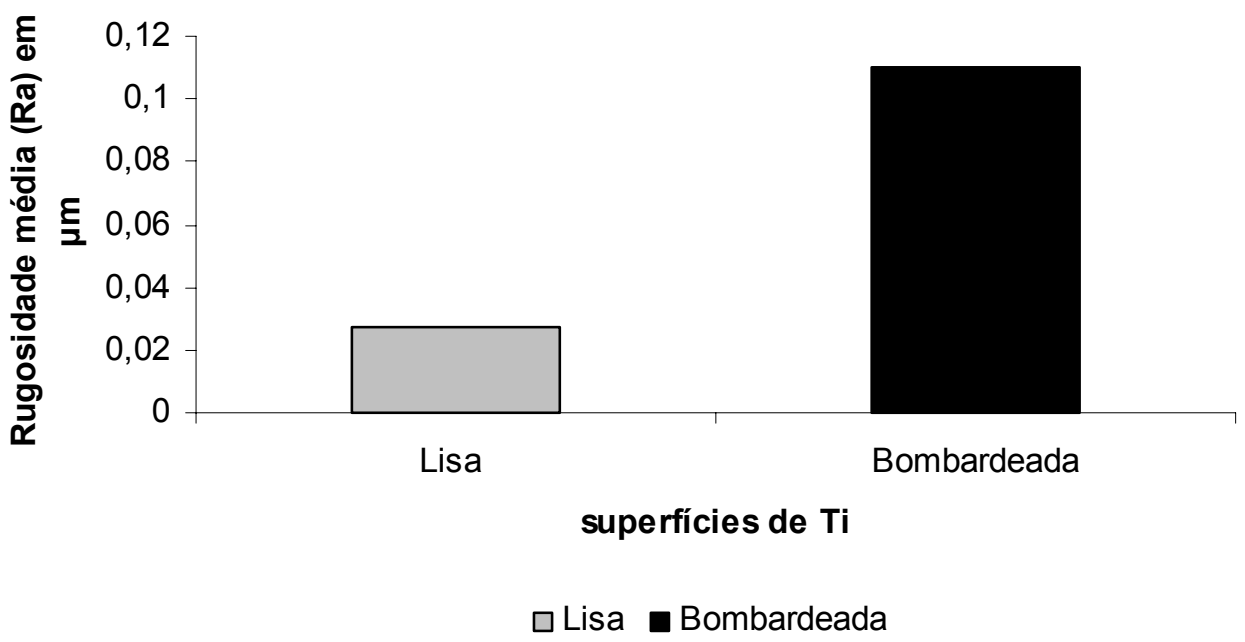

Figura 10 - Rugosidade média (Ra) das superfícies de Ti lisa e tratada a plasma em atmosfera de argônio

\subsubsection{Topografia}

A superfície de titânio tratada em atmosfera de argônio, quando observada em microscopia de luz refletida revelou-se marcada por irregularidades aparentemente uniformes, diferente da superfície apenas polida (lisa) e que não recebeu tratamento (Figura 11). 

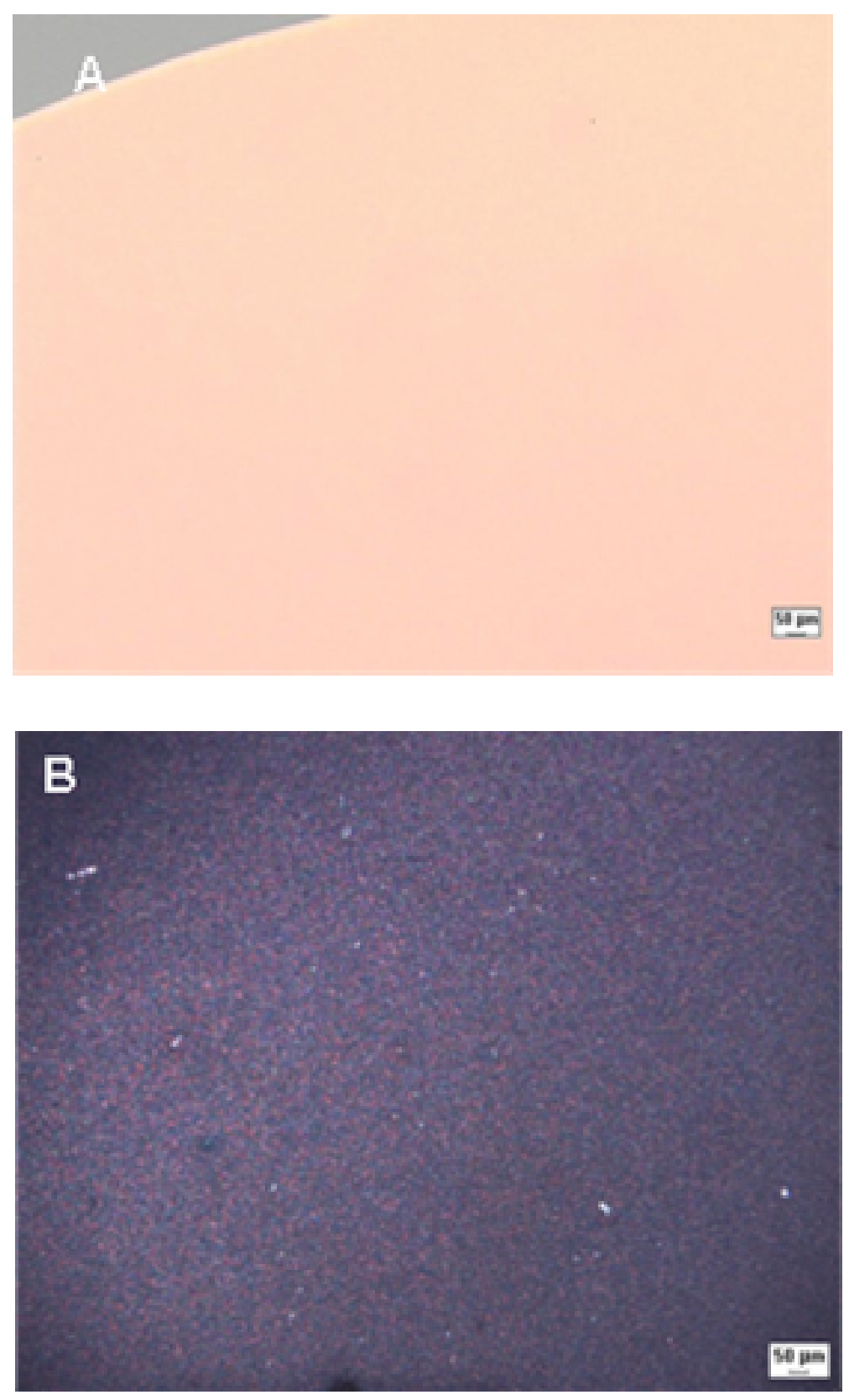

Figura 11 - Fotografia das superfícies dos discos de Ti obtidas no microscópio de luz refletida. ASuperfície lisa do disco após polimento. B - Amostra bombardeada com íons de argônio. Observar as rugosidades uniformes na superfície 
$\mathrm{Na}$ microscopia eletrônica de varredura a superfície tratada com argônio apresentou textura rugosa, com precipitados (pontos acinzentados) finamente dispersos (Figura 12).
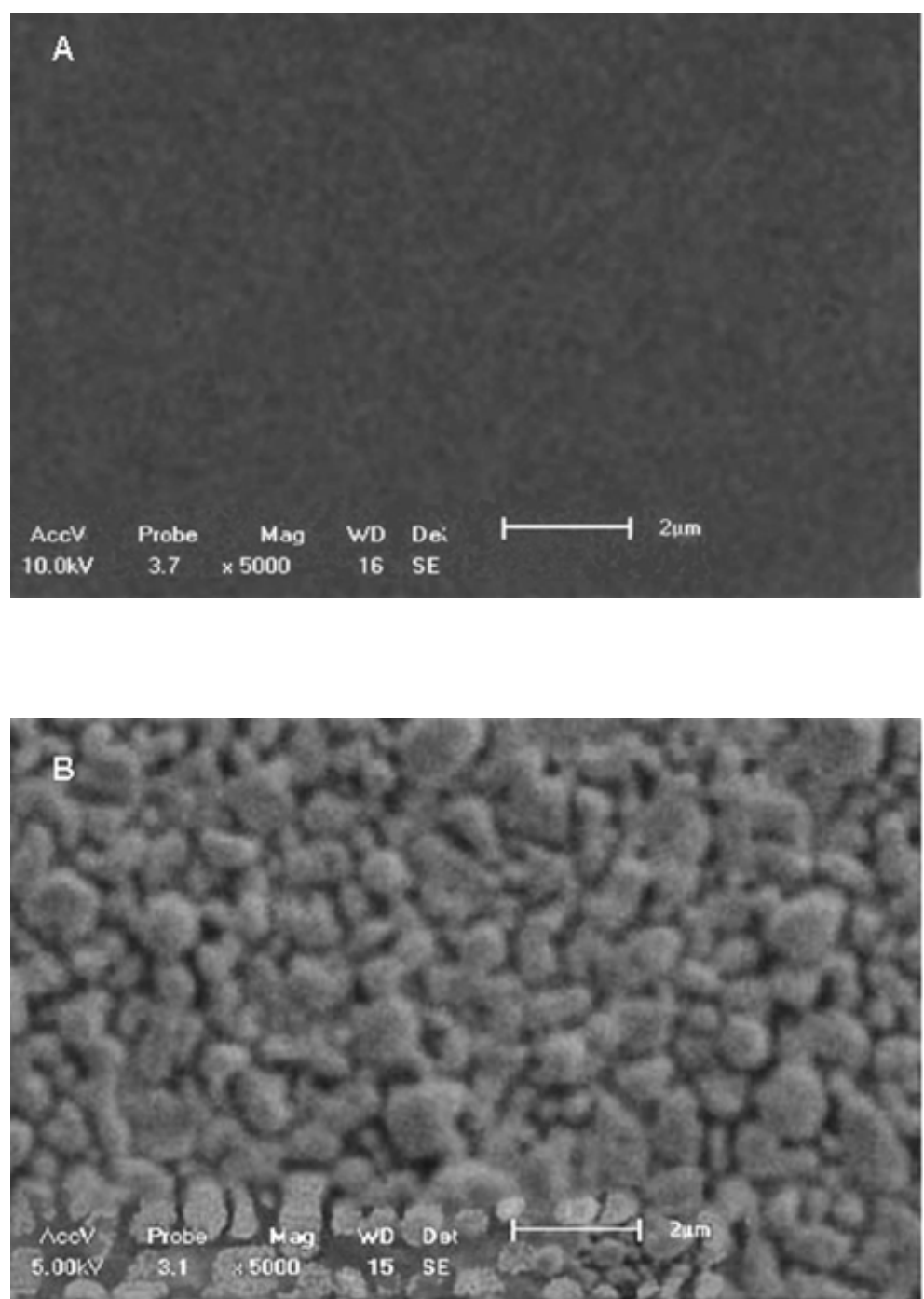

Figura 12 - Eletrofotomicrografias das superfícies de Ti. A - Topografia da superfície de Ti lisa. BObservar textura rugosa com precipitados dispersos da superfície bombardeada com argônio 


\subsection{GENOTOXICIDADE E MUTAGENICIDADE DAS SUPERFÍCIES DE TI}

Foram realizados testes de Ames e cometa para avaliar o potencial mutagênico e genotóxico dos discos de Ti bomabardeado e liso.

\subsubsection{Teste Ames}

Em todos os testes, o número de colônias revertentes para o grupo controle negativo foi dentro da escala histórica de dados do Laboratório de Mutagênese Ambiental (LAMA-UFRN). O grupo controle positivo foi obtido a partir de mutágenos conhecidos para as cepas TA98 e TA100: 4-nitroquinolina (4NQO) e ázida sódica, respectivamente. $\mathrm{O}$ número de colônias revertentes mostrou-se significativamente aumentado quando comparado ao grupo controle negativo, o que comprovou a acurácia dos ensaios.

A avaliação do potencial mutagênico com o Teste de Ames mostrou que o tratamento de plasma em atmosfera de argônio não produziu uma superfície mutagênica quando testadas com as cepas TA98 e TA100 (Tabela 1). As superfícies não tratadas também se mostraram não mutagênicas.

Tabela 1 - Reversão de cepas de Salmonella typhimurium no teste de Ames em superfícies de titânio tratadas a plasma e não-tratadas - São Paulo 2007

\begin{tabular}{lcr}
\hline & TA 98 & TA 100 \\
\hline Tratamentos & $\begin{array}{c}\mathbf{N}^{\circ} \text { médio } \\
\text { de revertentes }\end{array}$ & $\begin{array}{c}\mathbf{N}^{\circ} \text { médio } \\
\text { de revertentes }\end{array}$ \\
\hline Controle negativo & $24,60 \pm 3,11$ & $181,00 \pm 25,33$ \\
Controle positivo & $6274,00 \pm 1024$ & $2316,80 \pm 466,8$ \\
Superfície lisa & $28,00 \pm 4,35$ & $151,66 \pm 14,29$ \\
Superfície tratada & $36,00 \pm 11,24$ & $171,00 \pm 36,37$ \\
a plasma & & \\
\hline * $\mathrm{RM}=$ razão de mutagenicidade. Se RM $\geq 2,00$ em ao menos uma das linhagens estudadas, a \\
amostra analisada é considerada mutagênica
\end{tabular}




\subsubsection{Teste Cometa}

Foram avaliados 100 nucleóides por amostra de Ti ao microscópio de fluorescência. A princípio, este método visual permitiu observar a presença de danos no DNA das células CHO-K1 em níveis elevados: categorias 1 e 4 dos cometas (Figura 13). Entretanto, usando o teste de ANOVA, apenas os danos da categoria 4 foram significativos em relação às superfícies não tratadas. A superfície tratada a plasma não induziu rupturas significativas no DNA.

Os resultados obtidos com o ensaio do cometa em células CHO-K1 cultivados por 4 dias sobre as superfícies de Ti tratadas em plasma com atmosfera de argônio e em superfícies apenas polidas e o respectivo controle negativo (plástico do poço das placas de cultura) estão apresentados na figura 14. falta citar no texto tabela 2.

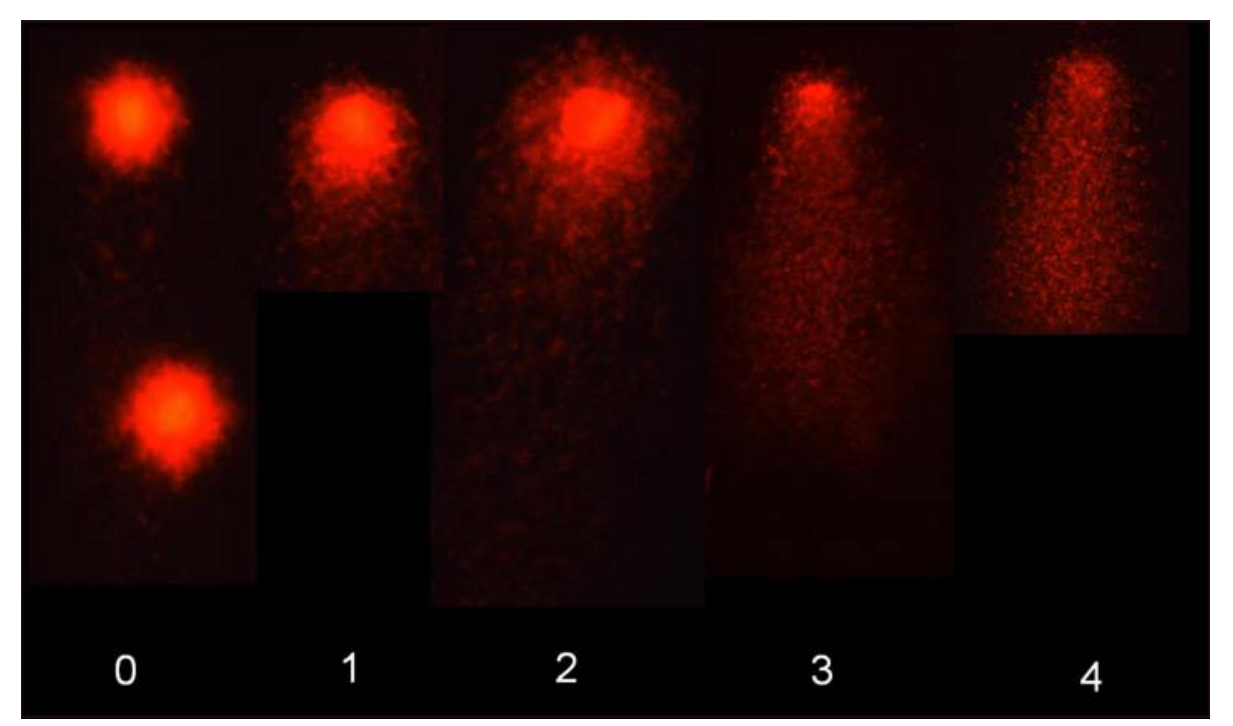

Figura 13 - Imagens representativas das categorias de cometas resultantes dos danos ao DNA nas células CHO-K1. $0-1$ são indicativos dos níveis de lesão ao DNA, vai de 0 que corresponde ao nucleóide sem dano até 4 , maior nível de lesão ao DNA 
Tabela 2 - Número médio de células que apresentaram danos no DNA de acordo com os níveis de lesões, avaliados por meio do teste de cometa em células CHO-K1 sobre as superfícies de Titânio - São Paulo - 2007

\begin{tabular}{cccc}
\hline Níveis & Superfície tratada & Superfície não-tratada & Controle negativo \\
\hline 0 & $69,70 \pm 19,60$ & $51,30 \pm 4,16$ & $81,00 \pm 10,58$ \\
1 & $12,00 \pm 4,36$ & $15,00 \pm 3,61$ & $13,30 \pm 11,37$ \\
2 & $4,00 \pm 4,36$ & $5,70 \pm 2,31$ & $2,00 \pm 3,46$ \\
3 & $5,30 \pm 3,51$ & $8,70 \pm 1,15$ & $2,00 \pm 2,65$ \\
4 & $9,00 \pm 7,94$ & $19,3 \pm 2,89^{*}$ & $1,30 \pm 1,15$ \\
\hline \multicolumn{4}{c}{ * Difere significativamente $(p<0.05)$ da superfície tratada e do controle }
\end{tabular}

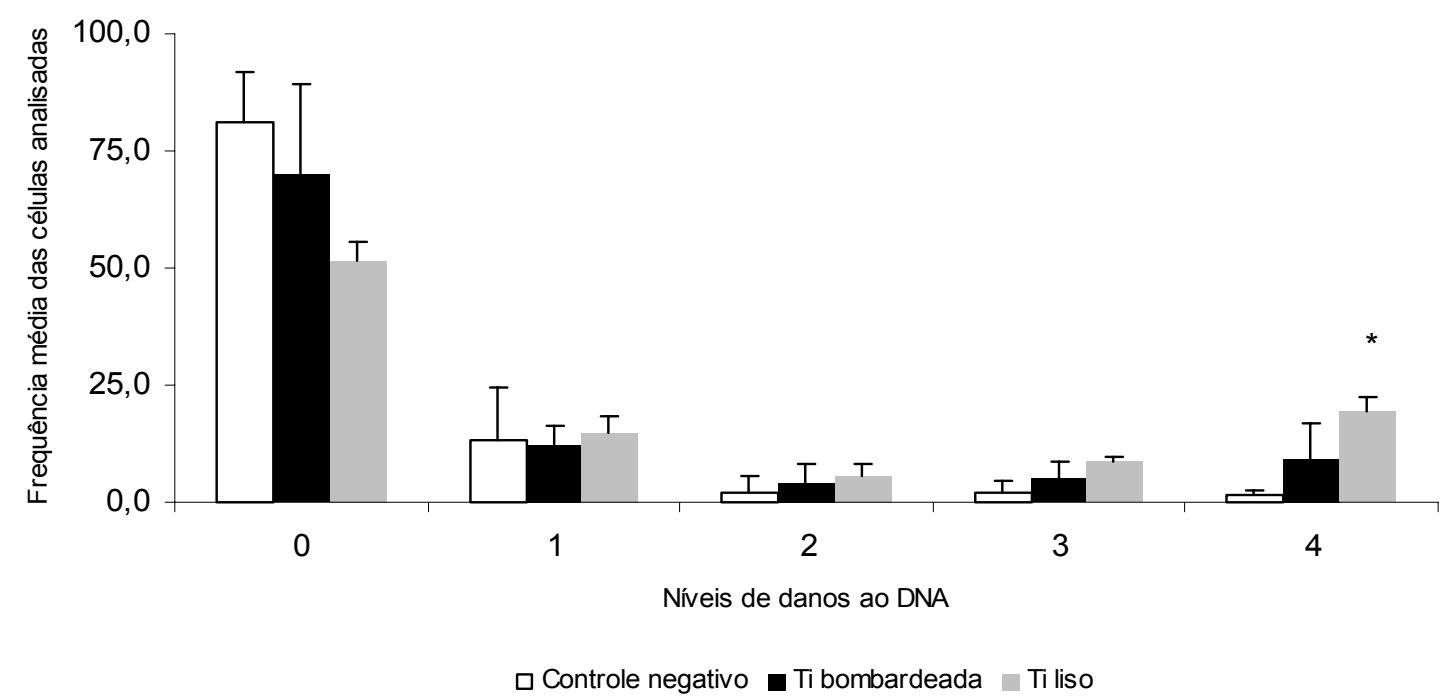

Figura 14 - Freqüências médias de células CHO-K1 que apresentaram danos no DNA de acordo com os níveis de lesões, avaliados por meio do teste de cometa sobre as superfícies de Titânio. * indica diferença significativa $(P<0.05)$

\subsection{MORFOLOGIA DOS PRÉ-OSTEOBLASTOS}

A influência da superfície sobre a morfologia dos pré-osteoblastos foi avaliada por meio de microscopia de luz refletida, eletrônica de varredura e de força atômica. 


\subsubsection{Microscopia de luz refletida e eletrônica de varredura}

$\mathrm{Na}$ análise ao microscópio óptico de luz refletida foi possível observar um filme composto de células e matriz extracelular recobrindo parte da superfície dos discos, contornando as irregularidades da superfície (Figura 15).

Entretanto, a visualização das amostras no MEV permitiu observar células poligonais e alongadas emitindo prolongamentos em ambas as superfícies. Entretanto, a concentração de células foi visivelmente maior nas superfícies rugosas nos dias 3,7 e 11 . Ainda se observou que aparentemente o número de projeções é maior nas células sobre as superfícies bombardeadas (Figura 16).
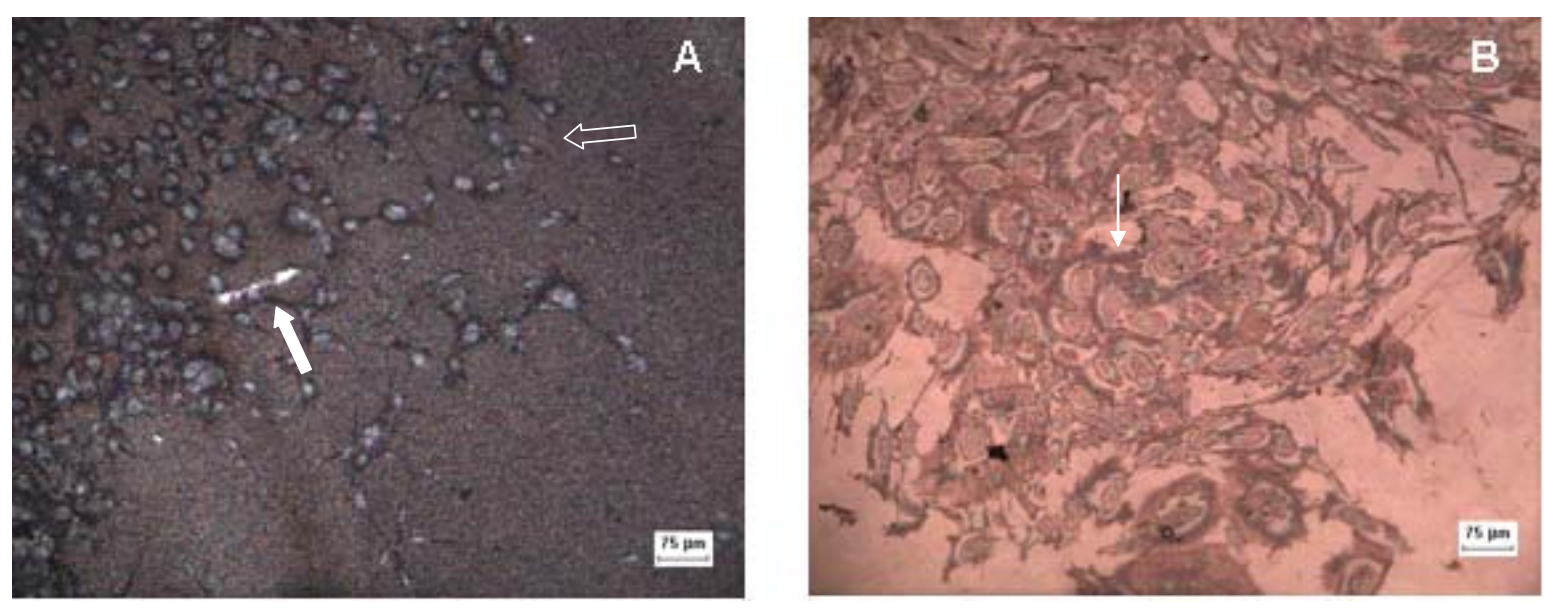

Figura 15- Fotomicrografias das células pré-osteoblásticas sobre a região de transição (região entre o centro e periferia) dos discos de Titânio obtidas em microscópio de luz refletida após 11 dias de cultura. A - Observar que as células possuem um menor tamanho, formas mais poligonais e marcadas por vários prolongamentos (seta vazia). A seta cheia indica um risco provocado por pinça para remover o biofilme que estava aderido a superfície de Ti bombardeada. B - Células maiores, porém com forma mais regular. A seta indica o biofilme produzido pelas células 

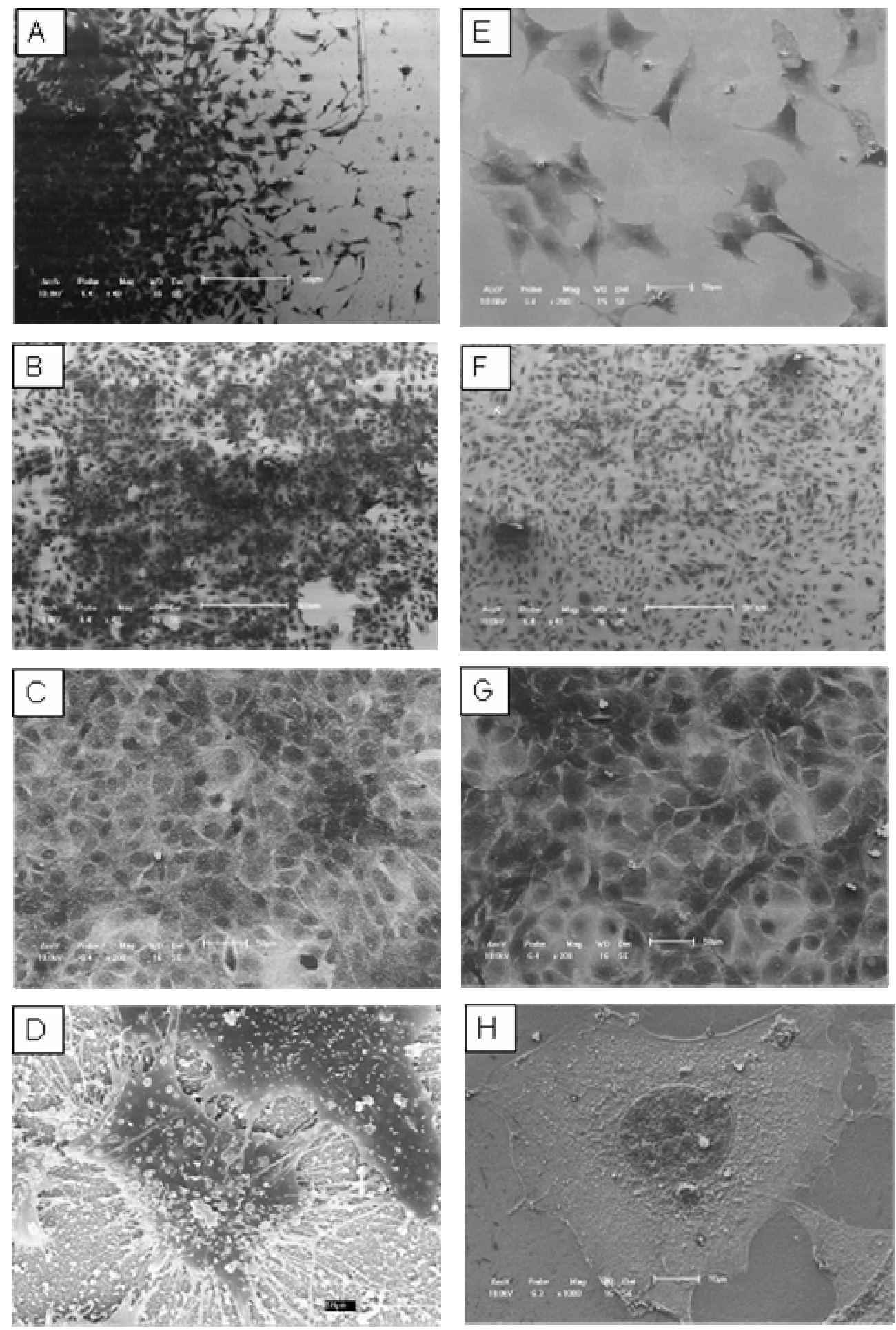

Figura 16 - Células pré-osteblásticas (CPO) cultivadas por 3, 7 e 11 dias sobre discos de Ti bombardeados por argônio e lisos. As imagens A, B e C são de CPO cultivadas por 3, 7 e 11 dias em superfícies tratadas, respectivamente. Em D, observar célula poligonal marcadas por vários prolongamentos. Enquanto as imagens $E$ - $G$ foram obtidas de CPO sobre superfície lisa cultivadas nos mesmos tempos. Na figura F, há CPO maiores e com formato arredondado na superfície lisa 
Os resultados da análise da forma das células aderidas às superfícies de $\mathrm{Ti}$ mostraram que a textura da superfície influencia sua morfologia. O coeficiente do fator forma dos pré-osteoblastos na superfície bombardeada foi significativamente menor $(p<0,05)$ isso indica predominância de células alongadas com numerosos prolongamentos (Figura 17).

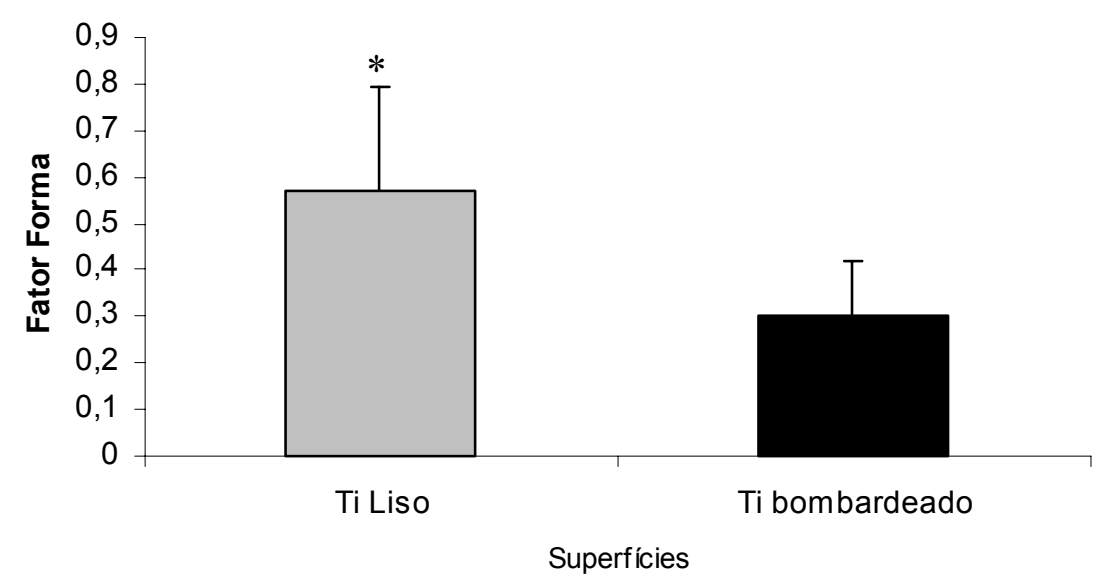

Figura 17- Coeficiente do fator forma dos pré-osteoblastos cultivados por $72 \mathrm{~h}$ sobre $\mathrm{Ti}$ bombardeado com íons de argônio e Ti liso. O fator forma é definido como [(área/perímetro $\left.{ }^{2}\right) \times 4 \pi$ ], quando igual a 1 refere-se a um circulo e 0 a uma reta. Quanto menor o fator forma mais alongadas são as células. Cada barra representa a média \pm desvio padrão do coeficiente do fator forma de 100 células de cada tratamento. ${ }^{*} p<0,0001$ indica diferença estatisticamente significativa

A análise do fator forma e a observação por MEV das características das células aderidas às superfícies do biomaterial permitiu classificar as células em três tipos: Tipo I, II e III. Tipo I apresentou valores de FF entre 0 e 0,33; neste caso a célula possuía um forma irregular ou estrelada marcada por numerosas extensões. Tipo II - forma elíptica ou alongada com FF entre 0,34 e 0,66. Tipo III - célula arredondada e os valores de FF entre 0,67 a 1,0. Houve uma predominância de células tipo I na superfície bombardeada (Figura 18). 


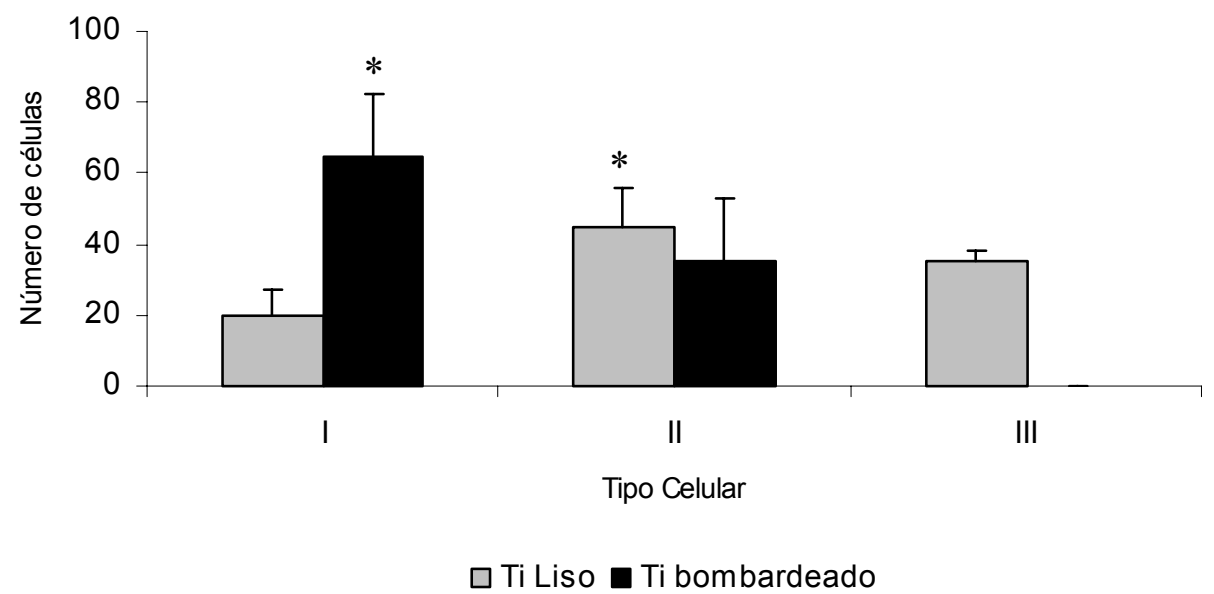

Figura 18 - Distribuição relativa dos tipos I, II e III de pré-osteoblastos em função do substrato. Cada barra corresponde à média \pm desvio padrão da porcentagem dos tipos celulares representativos, obtidos a partir de 100 células de cada tratamento. $\mathrm{O}$ tipo I predominou no Ti bombardeado, enquanto o II na superfície lisa. As células tipo III não foram encontradas na superfície bombardeada. Células cultivadas sobre a superfície bombardeada foram significativamente mais alongadas com numerosas extensões celulares comparada com a lisa. * indica diferença significativa $(p<0,001)$

\subsubsection{Microscopia de força atômica}

As imagens obtidas por microscopia de força atômica permitiram observar a tendência das células se alongarem e emitiram mais prolongamentos nas superfícies bombardeadas (Figuras 19 e 20).

O software analisador de imagem da AFM permitiu calcular rugosidade média (Ra) em uma varredura de $50 \mu \mathrm{m}^{2}$ da superfície de cada amostra, em função do tempo de cultura e da superfície. Observou-se que Ra foi tempo-dependente para ambas as superfícies, entretanto houve tendência a ser maior nas bombardeadas (Tabela 3). 
Tabela 3- Rugosidade média ( $\mathrm{Ra}$ ) em $\mu \mathrm{m}$ obtida pelo AFM das células préosteblásticas e sua matriz sobre as superfícies de Ti bombardeada e lisa - São Paulo - 2007

\section{DIAS DE CULTIVO}

\begin{tabular}{l|l|l|l}
\hline SUPERFÍCIES & $\mathbf{3}$ & $\mathbf{7}$ & $\mathbf{1 1}$ \\
\hline Bombardeada & 0,074 & 0,077 & 0,167 \\
\hline Lisa & 0,071 & 0,073 & 0,137 \\
\hline
\end{tabular}


a)

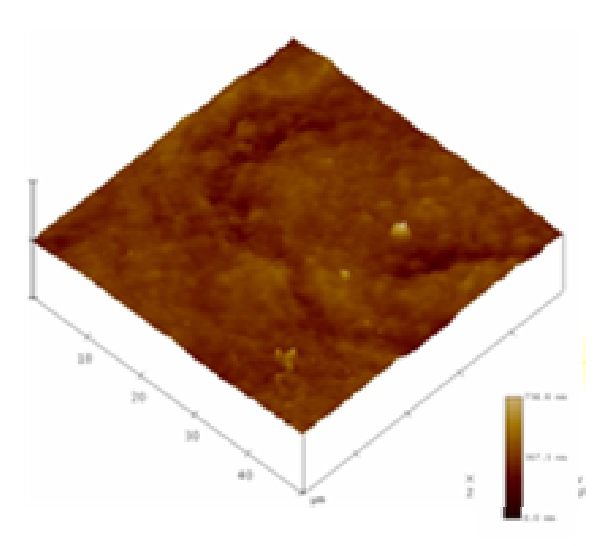

b)

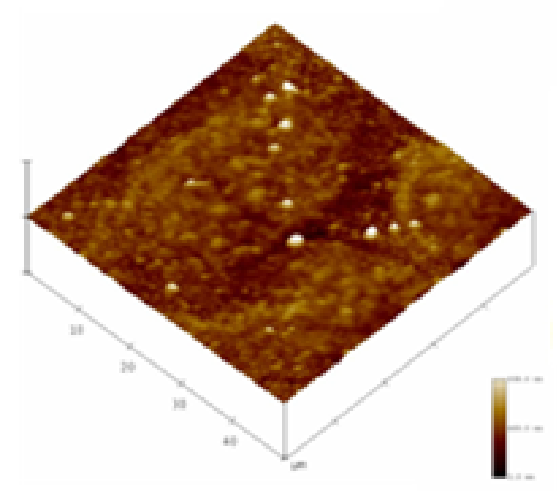

c)

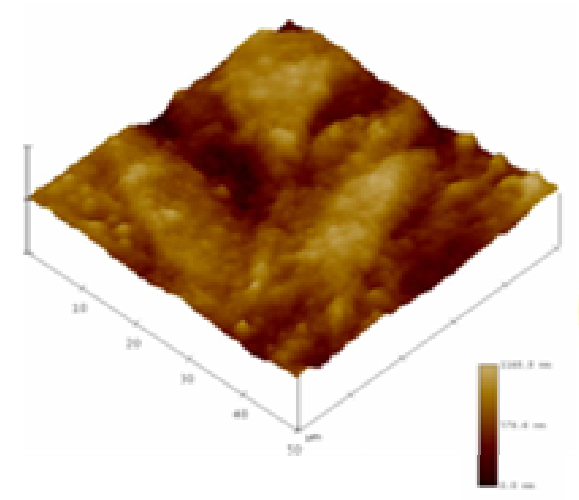

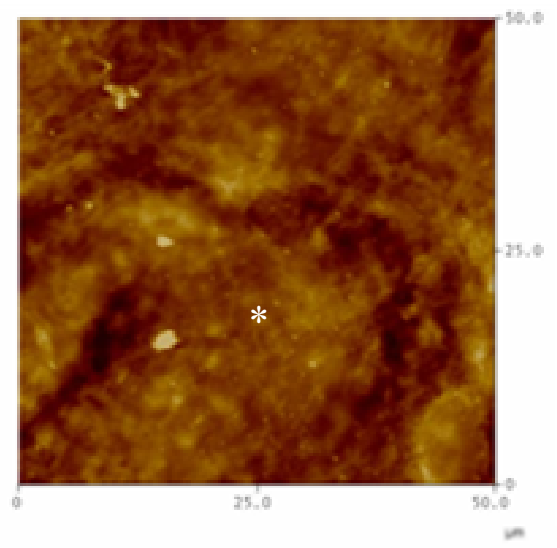
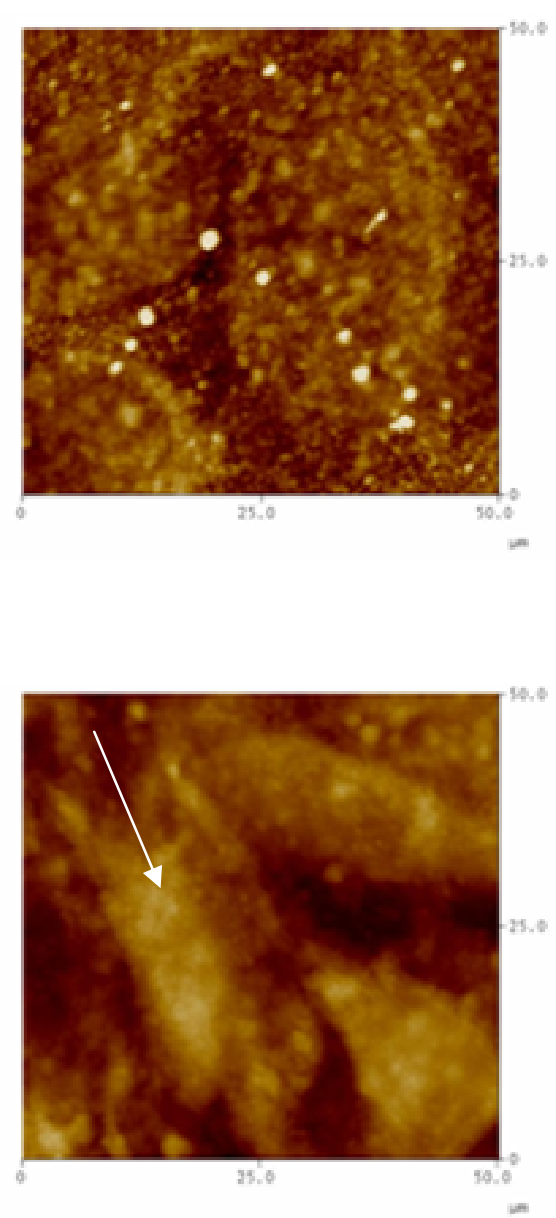

Figura 19- Imagens de microscopia de força atômica de células pré-osteblásticas e sua matriz extracelular sobre a superfície de discos de Ti bombardeadas com íons de argônio. (a) Células pré-osteblásticas com forma mais arredondada no $3^{\circ}$ dia de cultura $\left(^{*}\right)$. (b) Observar maior rugosidade aos 7 dias. (c) Células com formato mais poligonal e marcada por vários prolongamentos $(\rightarrow)$ 
a)
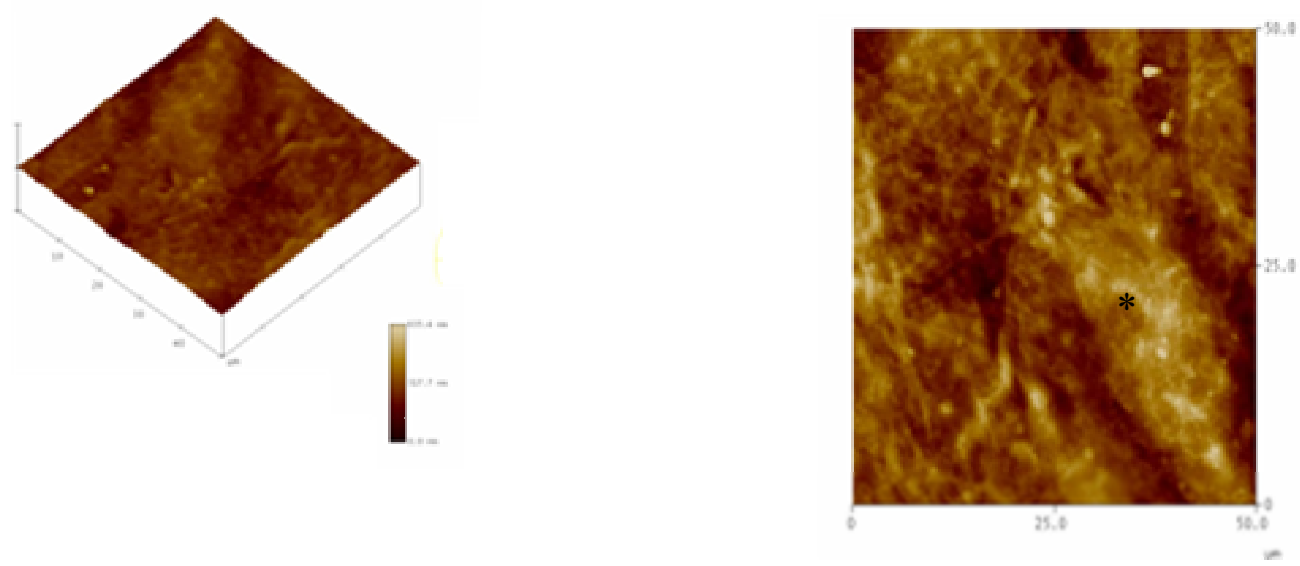

b)
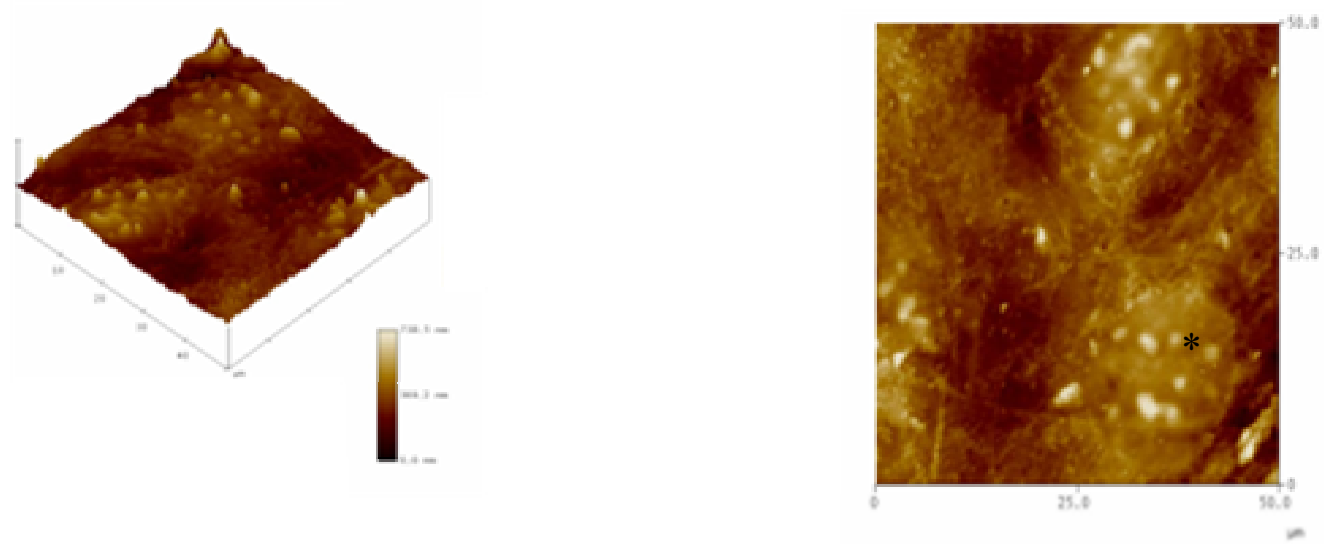

c)
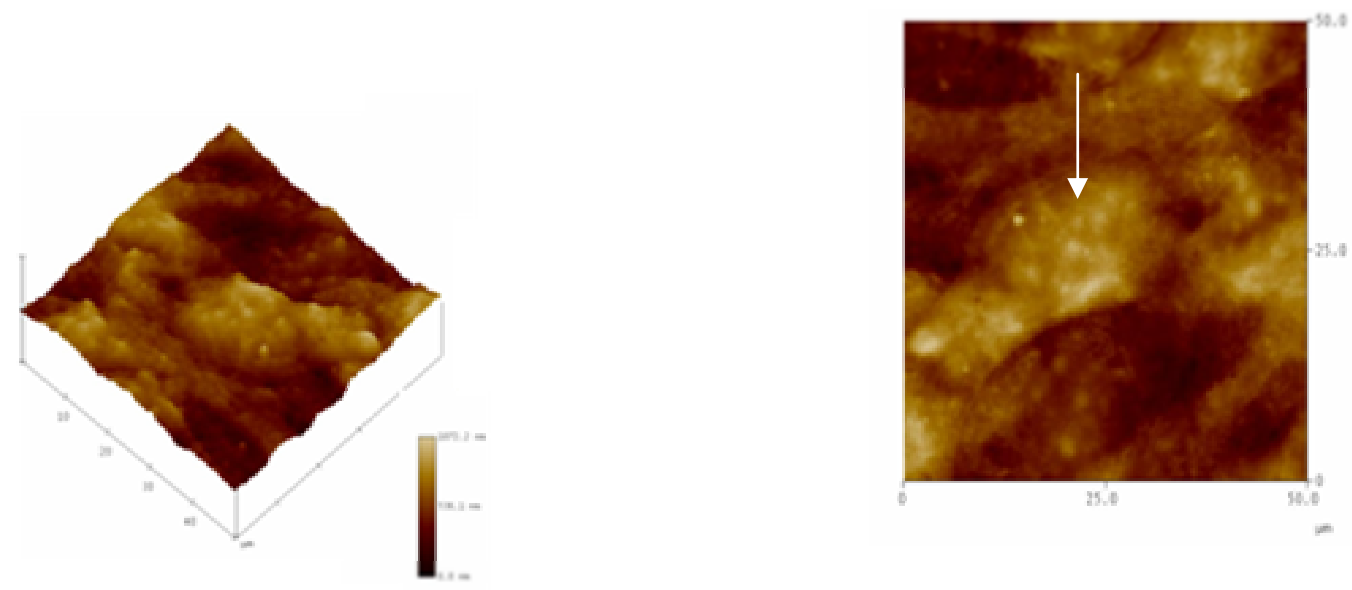

Figura 20- Imagens de microscopia de força atômica de células pré-osteblásticas e sua matriz extracelular sobre a superfície de discos de Ti não-tratadas. (a) Células pré-osteblásticas com forma mais arredondada nos 3 e 7 dia de cultura $\left(^{*}\right)$. (b) Observar células préosteoblásticas ainda arredondadas aos 7 dias $\left(^{*}\right)$. (c) Maior rugosidade e células com formato arredondado 


\subsection{PROLIFERAÇÃO DOS PRÉ-OSTEBLASTOS SOBRE AS SUPERFÍCIES DE TI}

A proliferação das células pré-osteblásticas sobre as superfícies lisa e bombardeada, foi avaliada por três diferentes métodos: contagem no hemocitômetro, por um sistema analisador de imagem (Imagen-pro plus ${ }^{\circledR}$ ) e de forma indireta pelo conteúdo de proteína total colhido de cada amostra.

A análise estatística dos resultados obtidos por contagem no hemocitômetro mostrou que houve diferença estatisticamente significativa entre a densidade celular (DC) quando comparadas às superfícies avaliadas (lisa e bombardeada, $p>0,001$ ) e entre a interação tempo vs. superfície $(p<0,001)$ nos dias 7 e 11 de cultivo. A avaliação entre os períodos de tempo mostrou que a DC aumentou em função dos dias de cultura para ambas as superfícies (Figura 21).

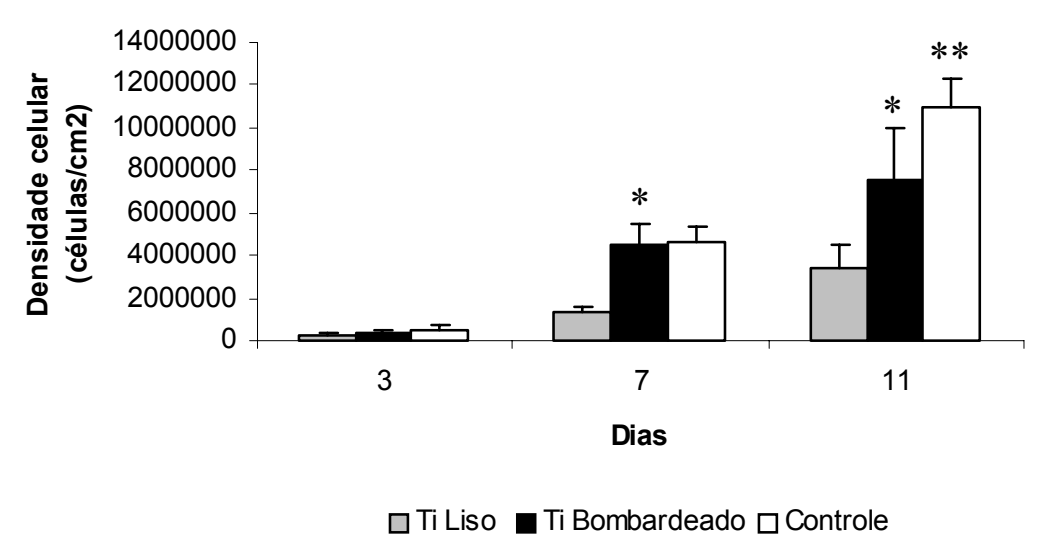

Figura 21 - Histograma da proliferação celular expressa em número de células por $\mathrm{cm}^{2}$ depois de 3,7 e 11 dias. Cada barra representa a média de pré-ostesblastos \pm desvio padrão $(n=3$ em cada grupo) de três experimentos iguais. * $p<0,001$ compara Ti bombardeado e liso; ${ }^{* *} p<0,001$ compara controle e Ti bombardeado

Os resultados da DC dos pré-osteoblastos sobre as superfícies de Ti obtida no sistema analisador de imagem confirmaram o aumento do número de células em função do tempo de cultivo e a maior proliferação sobre a superfície tratada nos dias 3 e $7(p<0,001)$, entretanto no dia 11 não houve diferença significativa $(p=0,082)$ (Figura 22). 


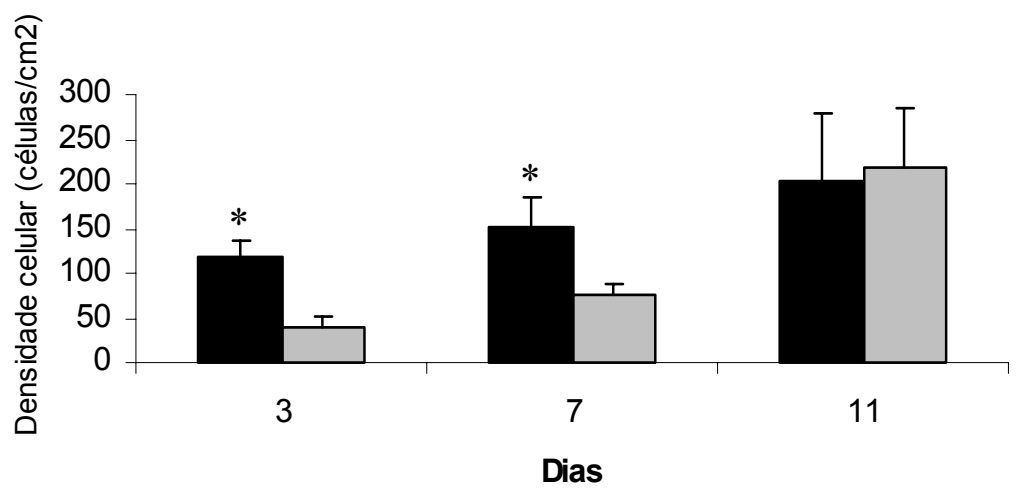

Figura 22 - Histograma da proliferação celular expressa em número de células por $\mathrm{cm}^{2}$ depois de 3,7 e 11 dias. Cada barra representa a média de pré-ostesblastos \pm desvio padrão $(n=3$ em cada grupo) de três experimentos iguais de contagem celular no sistema analisador de imagem. * indica diferença estatística entre as superfícies $p<0,001$

O conteúdo de proteína total (CPT) também se mostrou tempo-dependente e influenciado pela textura da superfície de $\mathrm{Ti}$ em todos os experimentos, com concentração máxima no dia 11. Os resultados podem ser observados na figura 23.

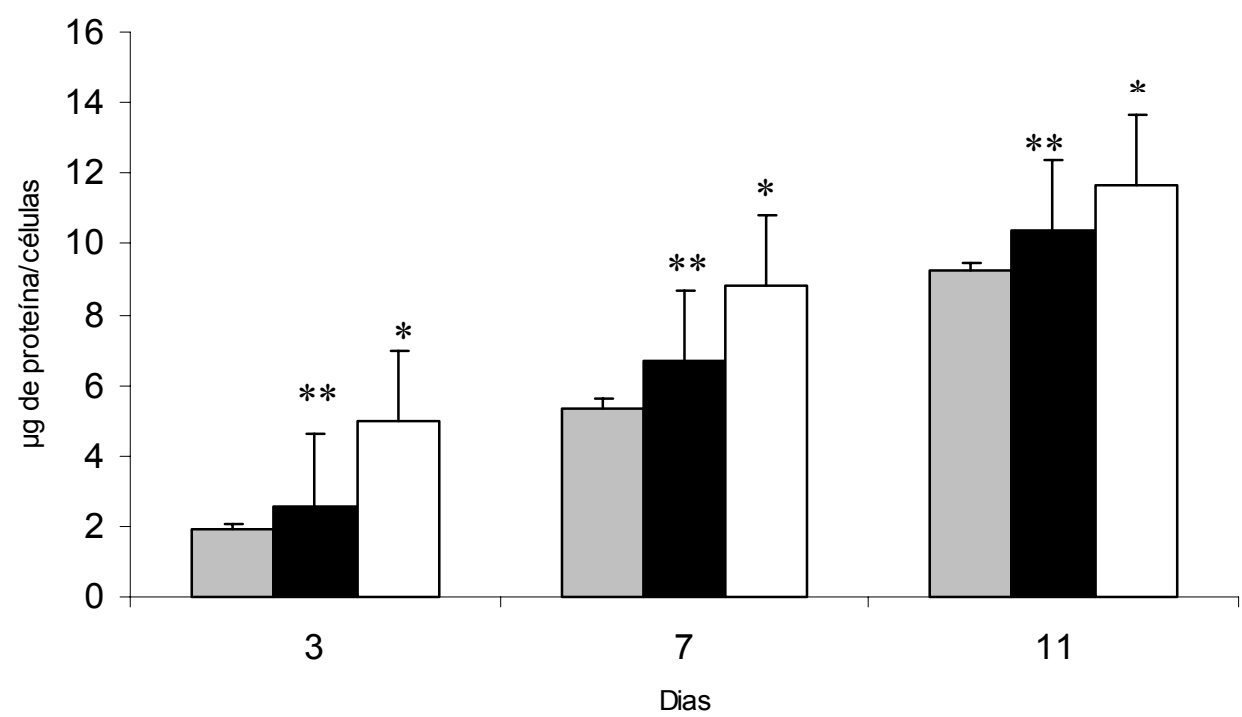

Ti Liso $\square$ Ti Bombardeado $\square$ Controle

Figura 23- Histograma do conteúdo de proteína total ( $\mu \mathrm{g} /$ células) normalizado para o número de células depois de 3,7 e 11 dias. * Indica diferença estatisticamente significativa entre controle e superfícies de Ti; ${ }^{* *}$ Mostra diferença entre as superfícies. Dados referentes a média \pm desvio padrão $(n=3$ para cada grupo) 


\subsection{ADESÃO DOS PRÉ-OSTEBLASTOS SOBRE AS SUPERFÍCIES DE TI}

$\mathrm{Na}$ figura 24 pode-se observar os resultados dos ensaios de adesão celular. A superfície bombardeada se mostrou mais eficaz como substrato de adesão para as células do que a superfície lisa $(p<0,05)$. Não foi observada diferença significativa quando se comparou adesão das células de uma mesma superfície em função do tempo de adesão.

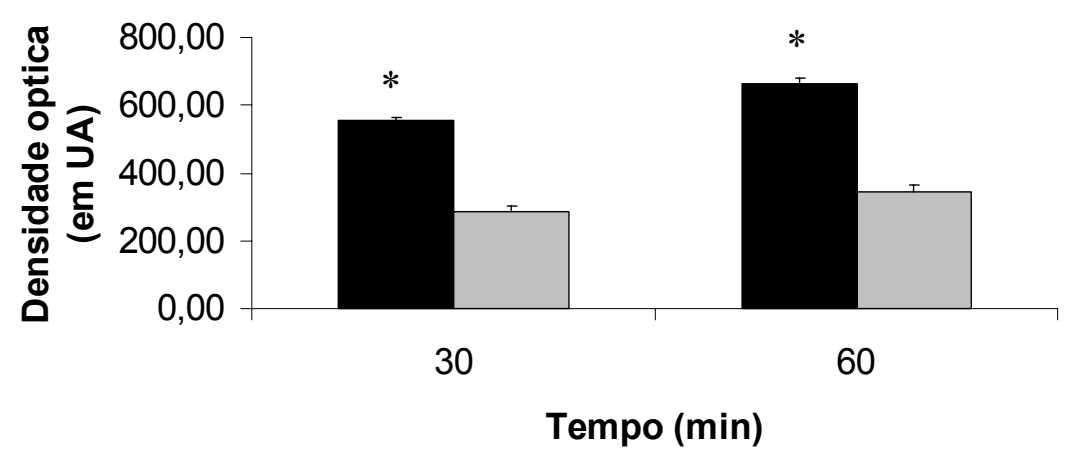

- Ti bombardeado $\square$ Ti Liso

Figura 24 - Histograma da densidade óptica (OD) de células pré-osteoblásticas aderidas nas superfícies de Ti. Cada barra representa a média das OD de células préosteoblásticas \pm desvio padrão ( $n=3$ em cada grupo) de três experimentos iguais. * Indica diferença estatisticamente significativa entre as superfícies de $\mathrm{Ti}$

\subsection{DIFERENCIAÇÃO DOS PRÉ-OSTEBLASTOS SOBRE SUPERFÍCIES DE Ti}

Para determinar se a interação das células MC3T3-E1 com a superfície de Ti modificou a expressão fenotípica das células, foram avaliados a atividade de fosfatase alcalina e a expressão de osteocalcina. 


\subsubsection{Atividade de fosfatase alcalina (ALP)}

A expressão da atividade de ALP foi monitorada a partir do meio condicionado da cultura das células sobre os discos de Ti 3, 7, 11 e 14 dias após serem plaqueadas. Não houve diferença significativa na atividade desta enzima entre as superfícies de Ti. Entretanto, após de 14 dias de cultura a produção de ALP foi maior nas células sobre as superfícies de Ti em relação ao plástico da placa de cultura $(p<0,05)$ (Figura 25).

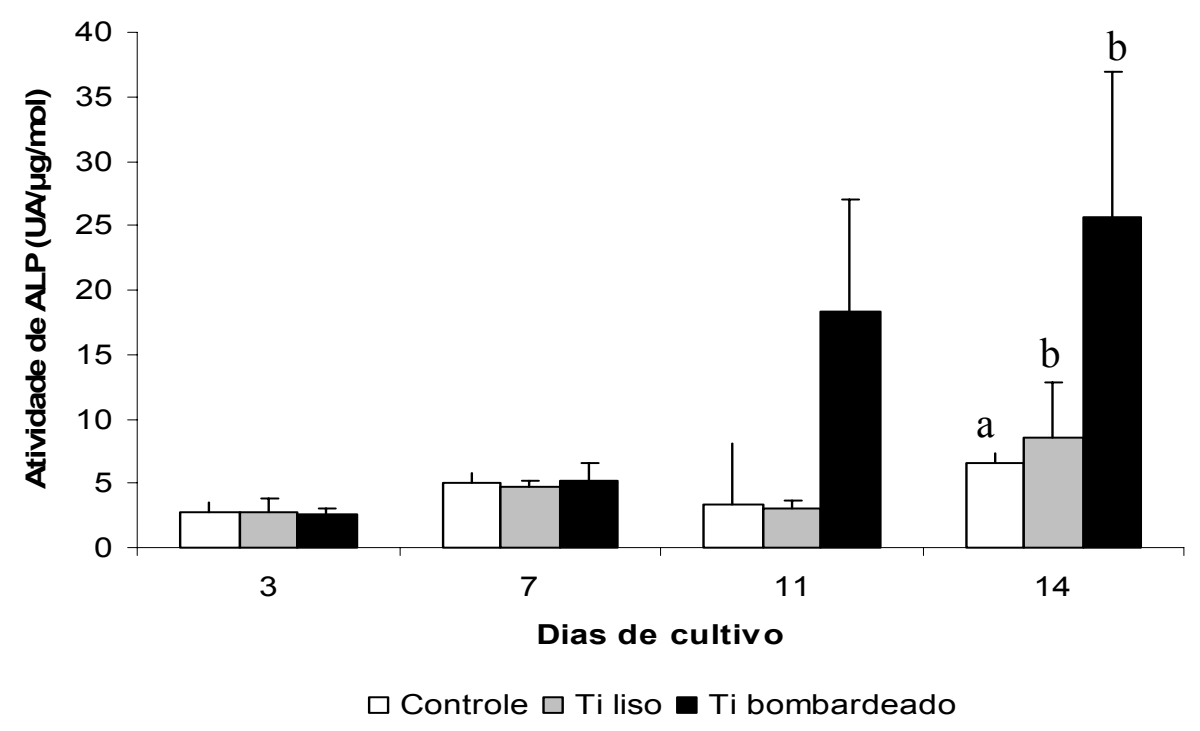

Figura 25 - Atividade de fosfatase alcalina (ALP) no meio condicionado de pré-osteoblastos sobre superfícies de Ti e no plástico de placas de cultura (controle) durante 3, 7, 11 e 14 dias de cultivo. ${ }^{a-b}$ diferença estatística entre as superfícies de $\mathrm{Ti}$ e o plástico da placa de cultura aos 14 dias 


\subsubsection{Análise de citometria de fluxo para osteocalcina}

A osteocalcina é um marcador especifico de células osteogênicas. A média de células positivas para osteocalcina e a intensidade de fluorescência foram avaliadas por citometria de fluxo. Houve uma maior expressão deste marcador em células cultivadas por 14 dias sobre as superfícies bombardeadas, entretanto não foi observada diferença significativa entre as superfícies de Ti. Esse aumento foi significativo apenas nas células cultivadas sobre as superfícies de Ti em relação àquelas cultivadas sobre o plástico da placa de cultura que receberam também os fatores indutores osteogênicos (controle positivo). Resultados semelhantes foram observados em relação à intensidade de fluorescência (Figura 26).

A

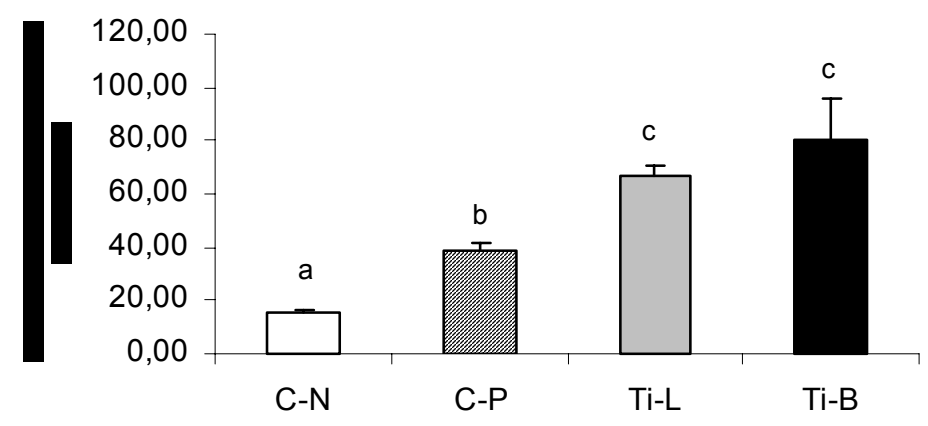

B

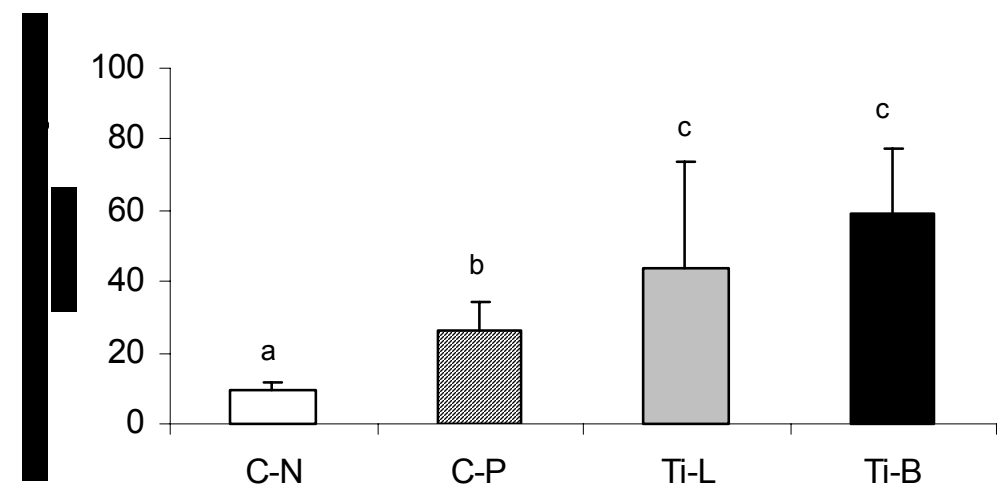

Figura 26 - Expressão de osteocalcina. A- células positivas para este marcador e B- Intensidade de fluorescência para osteocalcina de células cultivadas sobre diferentes superfícies e avaliadas por citometria de fluxo após 14 dias de cultura. ${ }^{a-c}$ diferença estatística $(p<0,05)$. C-N= controle negativo (células sobre o plástico que não receberam fatores osteoindutores (ácido ascórbico e $\beta$-glicerofosfato); $C-P=$ controle positivo (células sobre o plástico e meio com fatores osteoindutores); Ti-L= média de células positivas cultivadas sobre superfície de Ti lisa e Ti-B= média de células positivas cultivadas sobre superfície de Ti bombardeada 
Discussão 


\section{DISCUSSÃO}

O conceito de osseointegração tem sido explicado como sendo a união estrutural e funcional entre o osso vivo e organizado e a superfície de um implante (JOLY; LIMA, 2003). A busca por implantes osseointegráveis iniciou-se em 1977 por Brånemark e colaboradores. As propriedades da superfície do implante têm papel fundamental na indução das respostas celulares necessárias para osseointegração (MALO et al., 2006; RIDLEY et al., 2006; MUHONEN et al., 2007).

Os implantes com superfícies rugosas são considerados mais osseointegráveis que aqueles com superfícies lisas (BUSER et al., 1991; KIM et al., 2006). Superficies de $\mathrm{Ti}$ rugosas pode ser obtidas por diferentes técnicas: ataque ácido, anodização, implantação iônica ou por tratamento mecânico, como jateamento. Todas têm como objetivo melhorar a interação dessas superfícies com células (JAYARAMAN et al., 2004; PALMA et al., 2005; GRÖSSER-SCHREIBER et al. 2006; CHIN et al., 2007; EISENBARTH et al., 2007). No presente estudo, a funcionalização da superfície de TiCP por meio do bombardeamento de íons argônio permitiu produzir um novo biomaterial. A avaliação da superfície deste material demonstrou que o tratamento mencionado modificou a rugosidade e molhabilidade do TiCP. Além disso, este material se mostrou biocompatível com preosteblastos.

Dados históricos mundiais revelam que até a década de 80, aproximadamente cem milhões de implantes metálicos foram colocados em seres humanos, e estima-se que com os avanços tecnológicos e maior longevidade da população mundial esses números sejam proporcionalmente maiores (AZEVEDO; HIPPERT, 2002). Estudos têm mostrado ainda que pacientes com implantes apresentam maior susceptibilidade ao câncer quando comparados com uma população genérica (DORA et al., 1998). Segundo a Agência Internacional para Pesquisa sobre Câncer (IARC) existem vários casos de neoplasias no local de implantes metálicos associados a osso ou tecido mole. Foram relatados doença de Hodgkin, linfomas, leucemia e câncer renal relacionadas a implantes metálicos. Treze casos de câncer de mama associados ao uso de marcapasso, 7 de tumores cerebrais associados a próteses metálicas substituindo ossos do crânio, entre vários outros relatos (MCGREGOR et al., 2000). Na Medicina Veterinária, existe registro de 
60 casos de osteosarcomas primários em cães com pinos metálicos (LI et al., 1993). Estes relatos enfatizam a importância de que todo biomaterial antes da aplicação em ensaios in vivo e a liberação de seu uso para produção de implantes e dispositivos ortopédicos deve ser testado in vitro quanto a sua biocompatibilidade, genotoxicidade e mutagenicidade, (BEREND et al., 2006; LANDES et al., 2006; MEROLLI et al., 2006; BAGNO et al., 2007; BRAMA et al., 2007; GJURIC; RUKAVINA, 2007), por conseguinte a seleção adequada dos materiais metálicos biocompatíveis é muito importante. Assim, os testes Ames e Cometa foram aplicados a superfície de Ti bombardeado por argônio, estes testes são utilizados internacionamelmente como um sistema de triagem para detectar o potencial genotóxico e mutagênico de novos químicos e drogas em decorrência de sua alta preditividade em relação a carcinogênese (MCCANN et al., 1975; ROSS et al., 1995). Observamos que os materiais testados no presente trabalho (discos de TiCP lisos e bombardeados) não foram mutagênicos. Achados semelhantes foram descritos por Assad et al. (2002) ao aplicar o teste Ames também para TiCP e por Russell e Yiming (1998) ao avaliar a biocompatibilidade em discos de TiCP, bem como ligas ( $\mathrm{Ti}-\mathrm{Ag}, \mathrm{Ti}-\mathrm{Co}, \mathrm{Ni}-\mathrm{Cr}$ ) comumente utilizadas em restaurações dentárias.

O Cometa é outro importante teste capaz de detectar quebras no DNA. A estimativa de danos no DNA usando o ensaio do cometa é resultado da complexa interação entre dois processos: danos no DNA e reparo (ativação ou inibição) (OLIVE; BANATH, 2006) quantificáveis por meio da análise do escore (COLLINS, 2004). No presente estudo, os resultados revelaram altos níveis de lesões ao DNA das células CHO-K1 nas superfícies de Ti liso, com predominância de lesões das categorias 1 e 4 , as quais correspondem a lesão fraca e muito forte, respectivamente. Entretanto, o nível 4 para as superfícies de $\mathrm{Ti}$ liso foi significativamente mais freqüente quando comparada as de Ti bombardeado. Esses achados juntamente com os resultados do teste Ames demonstraram que o TiCP bombardeado por argônio pode seguramente ser utilizado como biomaterial de implantes. Estes resultados indicam que as propriedades da superfície também são capazes de influenciar a genotoxicidade do material, o que está de acordo com McGregor et al. (2000). A caracterização das amostras bombardeadas revelou que estas superfícies foram mais hidrofílicas que as lisas. O bombardeamento provavelmente alterou a camada de óxido, promovendo uma maior hidratação que refletiu a melhor biocompatibilidade 
do Ti bombardeado (ZHU et al., 2004), o que está de acordo Chang et al. (2005) os quais observaram maiores lesões ao DNA em células cultivadas em superfície lisa.

Superfícies de Ti rugosas têm sido utilizadas com sucesso em próteses da cabeça do fêmur de cães (WALENCIAK et al., 1996) e para confecção de placas para fraturas distais de rádio e ulna de cães de raças pequenas (BRASIL et al., 2007). A rugosidade é um importante fator para a biocompatibilidade de superfícies

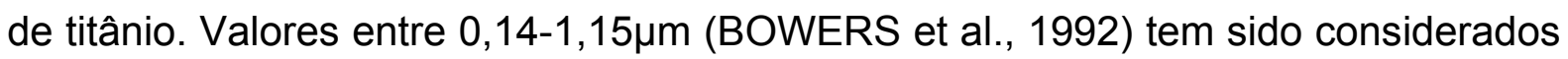
como um bom prognóstico para a osseointegração. Com o tratamento do TiCP, obtivemos valores de $\mathrm{Ra}(0,11 \mu \mathrm{m})$ menores do que encontrados na literatura. Porém, foi observada uma maior adesão e proliferação das células MC3T3-E1 em comparação com a superfície Ti lisa $(\mathrm{Ra}=0,027 \mu \mathrm{m})$. A avaliação da superfície deste material demonstrou que o tratamento mencionado permite modificar a textura do TiCP, resultando em superfícies com defeitos uniformes, como observado pela MEV (Figura 16). Esses dados levam a crer que a rugosidade não é o fator mais importante para a osseointegração e que outros fatores como topografia, profundidade, largura e distância entre os defeitos das superfícies devem ser observados. Devemos ainda ressaltar que a influência da configuração da morfologia de superfície dos implantes ao nível nanométrico sobre a resposta biológica aos implantes não é bem compreendida (COOPER et al., 1998; CASTELLANI et al., 1999; PARK; DAVIES, 2000). Acreditamos que a avaliação isolada da rugosidade de um implante em $\mu \mathrm{m}$ não seja um parâmetro ideal para a sua caracterização, pois superfícies com os mesmos valores de $\mathrm{Ra}$ podem apresentar morfologias diferenciadas (XAVIER, 2002) e mesmo um Ra maior não é garantia de sucesso, como foi descrito por Savarino et al. (2003) ao compararem a osseointegração de parafusos de Ti com superfícies rugosas, sendo uma 35\% mais rugosa que a outra. Estes parafusos foram introduzidos na tíbia de ovelhas por 12 semanas, ao final deste período, observaram maior quantidade de tecido fibroso entre a superfície com maior rugosidade e osso. Os autores associaram este fato a topografia da superfície. Enquanto, Vercaigne et al. (1998) ao testarem implantes de Ti com rugosidades diferentes $(16,5 ; 21,4$ e $37,9 \mu \mathrm{m})$, obtidas pelo tratamento de plasma em spray e introduzidos na tíbia de cabras por 3 meses, não observaram diferença na formação óssea e na força necessária para remoção do implante.

Outra aplicação do Ti, na Medicina Humana e Veterinária é na fabricação de grampos para homeostasia de artérias em vídeo-laparoscopias (SOARES et al., 
2001) Nossos achados referentes ao Ti bombardeado por argônio demonstram que este material pode ser uma excelente alternativa para produção destes grampos, por possuir uma rugosidade suficiente para promover a adesão celular, sem favorecer a

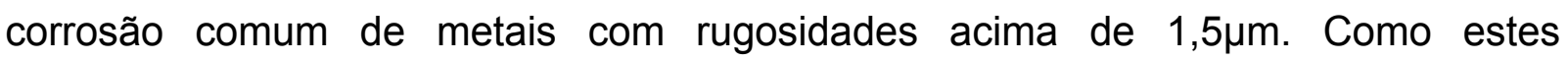
dispositivos ficam em contato intimo com tecidos moles, o uso de $\mathrm{Ti}$ com altas rugosidades poderia ser prejudicial por apresentarem maiores taxas de corrosão e de liberação de íons, predispondo a reações adversas no corpo. Além disso, os íons metálicos solúveis são agentes citotóxicos e cancerígenos (ALBREKTSSON, 1998).

As avaliações da resposta biológica in vitro deste novo biomaterial demonstraram que o comportamento das células pré-osteblásticas MC3T3-E1 foi influenciado pela topografia, rugosidade e molhabilidade da superfície de titânio submetidas ao processamento a plasma em atmosfera de argônio. Adesão foi uma das propriedades celulares analisadas. O método utilizado avalia a capacidade de interação das células com a superfície, ele deve ser realizado num intervalo de até de três horas, pois após esse período haverá muitas proteínas produzidas pelas células que se depositarão sobre a superfície testada, e nesse se caso se estará avaliando também a adesão das células sobre essas proteínas também (ROCHA et al., 2005). A superfície tratada com argônio se mostrou como melhor substrato para adesão por apresentar maior rugosidade, conseqüentemente, maior quantidade de vales, cristas, poros e sulcos, o que provavelmente facilitou as ligações de moléculas de adesão das células, como integrinas e proteoglicanos, por encontrarem regiões na superfície com as quais pudessem interagir e garantir a adesão celular. Esses resultados estão de acordo outros trabalhos que mostram que o aumento da rugosidade até certo ponto otimizaria a adesão osteoblástica (MARTIN et al., 1995; DELIGIANNI et al., 2001; ROSA; BELOTI, 2002).

O sucesso no uso de stents no tratamento para aneurismas da aorta abdominal, na cirurgia cardiovascular, depende de uma série de fatores, entre eles, da aderência da prótese a parede do vaso, além de concomitante proliferação da camada intima vascular sobre o implante para garantir a sua fixação, evitando deslocamentos (BOMBONATO et al., 2006). Atualmente, os stents são produzidos a partir do TiCP sem tratamento ou de aço inoxidável. $O$ uso de stents com superfície bombardeada por argônio poderia aumentar os índices de sucesso destes implantes, pelo fato da superfície favorecer a adesão celular, o que estaria de acordo com 
Haïdopoulos et al. (2006) que observou redução na corrosão e no processo de oxidação do Ti tratado com plasma spray usado na confecção de stents.

Com relação à proliferação celular, verificamos que a literatura apresenta resultados controversos. Alguns estudos mostraram que superfícies lisas favorecem proliferação celular (STANFORD et al., 1994; MARTIN et al., 1995; KIESWETTER et al., 1996). Entretanto, enquanto De Santis et al. (1996) e Hatano et al. (1999) observaram maior proliferação celular em células cultivadas sobre superfícies rugosas, Rosa e Beloti (2002), não verificaram diferença na proliferação celular sob diferentes condições de rugosidade. Entretanto, segundo Hunter et al. (1995) a resposta pode variar de acordo com o tipo de célula, fato que eles observaram ao testar superfícies rugosas as quais favoreciam a proliferação de osteoblastos, enquanto as lisas a de fibroblastos; resultados semelhantes foram encontrados recentemente por Grösser-Schreiber et al. (2006). Nossos ensaios de proliferação demonstraram que as superfícies submetidas ao processamento a plasma em atmosfera de argônio permitiram um aumento significativo do número de células em comparação aos dados com a superfície lisa. Esse dado pode ser atribuído ao aumento da rugosidade da superfície tratada, que permitiu a deposição de moléculas de matriz extracelular, citocinas, quimiocinas em microambientes (vales, cristas, poros e sulcos) facilitando assim as interações célula-matriz e célula-célula (WIELAND et al., 2005).

A maior molhabilidade das superfícies tratadas também favoreceu a maior proliferação dos pré-osteblastos, o que estaria de acordo com Chang et al. (2005) que observaram alto crescimento de osteoblastos MG-63 em superfícies hidrofilicas. Esse efeito deve-se ao fato da modulação de fatores de crescimento ser influenciada pelas propriedades da superfície. Os autores demonstraram que as superfícies hidrofóbicas prejudicaram a ativação de AKt e ERK, os quais são responsáveis pela progressão do ciclo celular, já que são necessárias para induzir a síntese de ciclina $D$, que por sua vez desencadeia a mudança da fase $G 1$ para $S$ promovendo a proliferação celular (CHANG et al., 2005).

Outra explicação para o maior crescimento nas superfícies tratadas é o fato da rugosidade aumentar a hidratação da camada de óxido da superfície (ZHU et al., 2004), e conseqüentemente aumentar a adsorção de proteínas do próprio meio na superfície (KASEMO, 2002). Da mesma forma nossos resultados de análise das imagens e Ra das superfícies Ti realizada pelo AFM, as quais revelaram maior 
rugosidade nas superfícies tratadas e aumento do Ra em função do tempo, o que provavelmente resulta da maior adsorção de proteínas do meio e deposição de moléculas de matriz extracelular produzidas pelas células aderidas.

Essas maiores taxas de adesão e proliferação de pré-osteoblastos na superfície de $\mathrm{Ti}$ bombardeada torna esse material uma alternativa importante para confecção de implantes osseointegráveis para odontologia, provavelmente essas maiores taxas garantirão uma rápida aposição de tecido ósseo, podendo reduzir o período de 3 a 6 meses de cicatrização livre de cargas, praticado atualmente (LENHARO; COSSO, 2004). O Ti bombardeado poderia também substituir o TiCP, utilizado desde 1970 na confecção de próteses dos componentes acetabulares e femorais para tratamento de displasias coxo-femoral de cães o que provavelmente poderia reduzir o período de 8 semanas do pós-operatório, e ainda o animal poderia apresentar melhoras mais rápidas nas taxas de movimentação da articulação e de ambulação normal, o que certamente aumentaria os índices de sucesso da operação (MINTO et al., 2006). Entretanto ainda são necessários testes in vivo para confirmação da aplicabilidade deste material.

Com relação à morfologia celular, foram evidenciadas diferenças que comprovam a influência da textura de superfície sobre as células cultivadas em discos de Ti. Foi possível observar células aderidas e espraiadas com características morfológicas de osteoblastos, isto é, com formatos poligonais, emitindo longos prolongamentos, e um filme composto de matriz extracelular e células recobrindo parte da superfície dos discos com maior freqüência nas superfícies tratadas, de forma semelhante ao relato de outros autores (ANSELME et al., 2000). Houve uma predominância de células tipo I (Figura 23) na superfície tratada, achados semelhantes foram descritos por Shah et al. (1999); Wieland et al. (2002) e Wieland et al. (2005).

Em geral, a expressão de proteínas celulares é sensível a diferentes tipos de material e topografias de superfície (LINCKS et al., 1998). Enquanto Castelanni et al. (1999) e Rosa e Beloti (2002) não encontraram diferenças significantivas na produção de proteínas entre superfícies diferentes, Martin et al. (1995) observaram inibição de produção protéica sobre substratos lisos. Tal discrepância de resultados poderia ser explicada pela diferença das superfícies com valores de Ra desiguais obtidas por diferentes métodos, ou pelo emprego de células de origens diferentes. 
Em nosso trabalho, a quantidade de proteínas foi menor nos discos com superfícies lisas.

A atividade da fosfatase alcalina (ALP) é convencionalmente utilizada como marcador inicial para diferenciação de pré-osteblastos (WANG et al., 1999). A ALP é uma enzima particularmente importante para células ostegênicas e possui papel fundamental na mineralização da matriz óssea (GRAZIANO et al., 2007). Nossos resultados demonstraram que não houve diferença significativa na atividade de ALP entre as superfícies de Ti, portanto o bombardeamento não foi suficiente para tornar a superfície mais osteointegrável que a lisa. Entretanto, após 14 dias de cultura, essa atividade foi significativamente maior nas superfícies de Ti em relação ao plástico de cultura, esse fato comprova o potencial osteointegrável destas superfícies, o que está de acordo com Liao et al. (2003) e Lee et al. (2004).

Ainda em relação aos ensaios de diferenciação, ALP não é um marcador especifico de osteblastos, como a osteocalcina (VIEIRA, 1999). As análises de citometria de fluxo para osteocalcina não revelaram diferença significativa na expressão deste marcador entre as células cultivadas nas superfícies de Ti, portanto

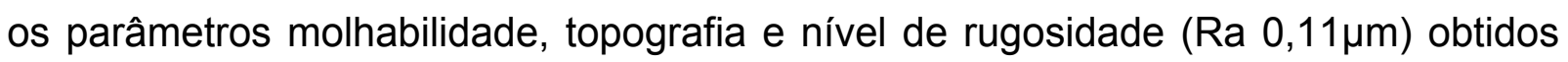
com o bombardeamento não influenciaram a expressão fenotípica das células MC3T3-E1, o que está de acordo com Ponader ${ }^{1}$ et al. (2007). Entretanto, outros parâmetros como a cristalografia da superfície foram capazes de influenciar a atividade de ALP de células MC3T3-E1 como foi demonstrado por Faghihi et al. (2006).

Nosso estudo in vitro forneceu uma contribuição para a compreensão da respostas celulares TiCP bombardeado por íons de argônio. Entretanto, futuramente uma complementação com estudos in vivo, utilizando esse material na confecção de implantes para tecido ósseo, permitiria uma melhor compreensão da influência desta superfície sobre a osseointegração.

\footnotetext{
1 PONADER, S.; VAIRAKTARIS, E.; HEINL, P.; WILMOWSKY, C.V.; ROTTMAIR, A.; KÖRNER, C.; SINGER, R. F.; HOLST, S.; SCHLEGEL, K.A.; NEUKAM, F.W.; NKENKE, E. Effects of topographical surface modifications of electron beam melted Ti$6 \mathrm{Al}-4 \mathrm{~V}$ titanium on human fetal osteoblasts. Journal of Biomedical Materials Research. Part A, 2007 [Epub ahead of print].
} 
Conclusão 


\section{CONCLUSÃO}

O bombardeamento de superfícies de Ti com íons de argônio produziu uma superfície biocompatível e promoveu melhora nos parâmetros avaliados em superfícies destinadas a implantes dentários e/ou ósseos, mas não foi capaz de influenciar a taxa de diferenciação celular. 
Referências 


\section{REFERÊNCIAS}

ACAR, A.; INAN, O.; HALKACI, S. Effects of airborne-particle abrasion, sodium hydroxide anodization, and electrical discharge machining on porcelain adherence to cast commercially pure titanium. Journal of Biomedical Materials Research. Part B: Applied Biomaterials, v. 82 , n. 1, p. 267-74, 2007.

ALBREKTSSON, T. Direct bone anchorage of dental implants. Journal of Prosthetic Dentistry, Saint Louis, v. 50, n. 1, p. 255, 1983.

ALBREKTSSON, T. Hydroxyapatite-coated implants: A case against their use. Journal of Oral and Maxillofacial Surgery, v. 56, n. 1, p. 1312-1326, 1998.

ALVES JR., C.; GUERRA NETO, C. L. B.; MORAIS, G. H. S.; DA SILVA, C. F.; HAJEK, V. Nitriding of titanium disks and industrial dental implants using hollow cathode discharge.

Surface and Coatings Technology, v. 200, n. 11, p. 3657-3663, 2006.

AMES, B.; LEE, F.; DURSTON, W. An improved bacterial test system for the detection and classification of mutagens and carcinogens. Proceedings of the National

Academy of Sciences of the United States of America, v. 70, n. 1, p. 782-786, 1973.

ANSELME, K.; LINEZ, P.; BIGERELLE, M.; LE MAGUER, D.; LE MAGUER, A.; HARDOUIN, P.; HILDEBRAND, H. F.; IOST, A.; LEROY, J. M. The relative influence of the topography and chemistry of TiAl6V4 surfaces on osteoblastic cell behaviour. Biomaterials, v. 15, n. 1 , p. $1567-1577,2000$.

ASSAD, M.; CHERNYSHOV, A.; LEROUX, M. A.; RIVARD, C. H. A new porous titaniumnickel alloy: part 2. Sensitization, irritation and acute systemic toxicity evaluation. BioMedical Materials and Engineering, v. 12, n. 4, p. 339-46, 2002.

ASSIS, O. B. G. Funcionalização de superfícies por plasma a Frio. Comunicado técnico EMBRAPA, v. 43, n. 1, p. 1-4, 2001.

AZEVEDO, C. R. F.; HIPPERT JR., E. Análise de falhas de implantes cirúrgicos no Brasil: a necessidade de uma regulamentação adequada. Caderno de Saúde Pública, v. 18, n. 5, p. 1347-1358, 2002.

BÄCHLE, M.; KOHAL, R. J. A systematic review of the influence of different titanium surfaces on proliferation, differentiation and protein synthesis of osteoblast-like MG63 cells.

Clinical Oral Implants Research, v. 15, p. 683-692, 2004. 
BAGNO, A.; PIOVAN, A.; DETTIN, M.; CHIARION, A.; BRUN, P.; GAMBARETTO, R.; FONTANA, G.; DI BELLO, C.; PALU, G.; CASTAGLIUOLO, I. Human osteoblast-like cell adhesion on titanium substrates covalently functionalized with synthetic peptides.

Bone, v. 40, n. 3, p. 693-699, 2007.

BAIER, R. E.; MEYER, A. E. Implant surface preparation. The International Journal of Oral \& Maxillofacial Implants, v. 3, n. 1, p. 9-20, 1988.

BEREND, M. E.; SMITH, A.; MEDING, J. B.; RITTER, M. A.; LYNCH, T.; DAVIS, K. J. Long-term outcome and risk factors of proximal femoral fracture in uncemented and cemented total hip arthroplasty in 2551 hips. Arthroplasty, v. 21, n. 6, p. 53-59, 2006.

BOMBONATO, R.; PALMA, J. H.; MARCONDES, J. A.; MORAES, A. N.; ROCHA, J. L.; MARTINS, M. R.; TCHAICK, R. M.; DOMINGOS, J.; BUFFOLO, E. Reação histopatológica da parede da aorta abdominal ao stent não recoberto. Brazilian Journal of Cardiovascular Surgery, v. 21, n. 2, p. 198-205, 2006.

BOSCHI, A. O. O que é necessário para que um material possa ser considerado biomaterial?. In: SEMINÁRIO DE BIOMATERIAIS, 1., 1996, Santa Catarina. Anais... Santa Catarina: UDESC, 1996. p. 4-16.

BOWERS, K. T.; KELLER, J. C.; RANDOLPH, B. A.; WICK, D. G.; MICHAELS, C. M. Optimization of surface micromorphology for enhanced osteoblast responses in vitro. The International Journal of Oral \& Maxillofacial Implants, v. 7, n. 3, p. 302-310, 1992.

BRADFORD, M. M. A rapid and sensitive method for the quantitation of microgram quantities of protein utilizing the principle of protein-dye binding. Analytical Biochemistry, v. 72, p. 248-254, 1976.

BRAMA, M.; RHODES, N.; HUNT, J.; RICCI, A.; TEGHIL, R.; MIGLIACCIO, S.; ROCCA, C. D.; LECCISOTTI, S.; LIOI, A.; SCANDURRA, M.; DE MARIA, G.; FERRO, D.; PU, F.; PANZINI. G.; POLITI, L.; SCANDURRA, R. Effect of titanium carbide coating on the osseointegration response in vitro and in vivo. Biomaterials, v. 28, n. 4, p. 595-608, 2007.

BRANEMARK, P. I.; ADELL, R.; BREINE, U.; HANSSON, B. O.; LINDSTRÖM, J.; OHLSSON, A. Intraosseous anchorage of dental protheses. I. Experimental studies.

Scandinavian journal of plastic and reconstructive surgery and hand surgery, v. $3, n$. 2, p. 81-100, 1969.

BRANEMARK, P. I.; HANSSON, B. O.; ADELL, R.; BREINE, U.; LINDSTRÖM, J.; HALLEN, O.; ÖHMAN, A. Osseointegrated implants in the treatment of edentulous jaw. Experience from a 10 year period. Scandinavian Journal of Plastic and Reconstructive Surgery and Hand Surgery, v. 16, n. 1, p. 1-132, 1977. 
BRASIL, F. B. J.; GIORDIANO, P. P.; RIBEIRO, M. C. L. Tratamento de fraturas distais de rádio e ulna em cães miniaturas. Revisão de literatura (Parte II). Boletim Médico Veterinário, v. 3, n. 3, p. 43-51, 2007.

BREME, J.; STEINHAUSER, E.; PAULUS, G. Commercially pure titanium steinhauser platescrew system for maxillofacial surgery. Biomaterials. v. 9, n. 4, p. 310-313, 1988.

BUSER, D.; SCHENK, R. K.; STEINEMANN, S.; FIORELLINI, J. P.; FOX, C. H.; STICH, H. Influence of surface characteristics on bone integration of titanium implants. A histomorphometric study in miniature pigs. Journal of Biomedical Materials Research, v. 25, p. 889-902, 1991.

CAMPOS JÚNIOR, A.; PASSANEZI, E. Porque a osseointegração revolucionou a implantodontia? In: TODESCAN, F. F.; BOTTINO, M. A. Atualização na clínica odontológica: a prática da clínica geral. São Paulo: APCD/Artes Médicas, 1996. p. 249297.

CASTELLANI, R.; DE RUIJTER, J. E.; RENGGLI, H.; JANSEN, J. A. Response of rat bone marrow cells to differently roughened titanium discs. Clinical Oral Implants Research, $v$. 10, n. 5, p. 369-378, 1999.

CHANG, E. J.; KIM, H. H.; HUH, J. E.; KIM, I. A.; KO, J. S.; CHUNG, C. P.; KIM, H. M. Low proliferation and high apoptosis of osteoblastic cells on hydrophobic surface are associated with defective Ras signaling. Experimental Cell Research, v. 303, n. 1, p. 197-206, 2005.

CHIESA, R.; GIAVARESI, G.; FINI, M.; SANDRINI, E.; GIORDANO, C.; BIANCHI, A.; GIARDINO, R. In vitro and in vivo performance of a novel surface treatment to enhance osseointegration of endosseous implants. Oral surgery, oral medicine, oral pathology, oral radiology and endodontics, v. 103, n. 6, p. 745-756. 2007.

CHIN, M. Y. H.; SANDHAM, A.; VRIES, J.; MEI, H. C. V.; BUSSCHER, H. J. Biofilm formation on surface characterized micro-implants for skeletal anchorage in orthodontics. Biomaterials, v. 28, n.1, p. 2032-2040, 2007.

COLLINS, A. R. The comet assay for DNA damage and repair: principles, applications, and limitations. Molecular Biotechnology, v. 26, n. 3, p. 249-261, 2004.

COOPER, L. F.; MASUDA, T.; WHITSON, S. W.; YLIHEIKKILÄ, P.; FELTON, D. A. Formation of mineralizing osteoblast cultures on machined, titanium oxide grit-blasted, and plasma-sprayed titanium surfaces. The International Journal of Oral \& Maxillofacial Implants, v. 14, n. 1, p. 37-47, 1999.

DE OLIVEIRA, P. T.; ZALZAL, S. F.; BELOTI, M. M.; ROSA, A. L.; NANCI, A. Enhancement of in vitro osteogenesis on titanium by chemically produced nanotopography. Journal of Biomedical Materials Research Part A, v. 80, n. 3, p. 554-564, 2007. 
DE SANTIS, D.; GUERRIERO, C.; NOCINI, P. F.; UNGERSBOCK, A.; RICHARDS, G.; GOTTE, P.; ARMATO, U. Adult human cells from jaw bones cultured on plasma-sprayed or polished surfaces of titanium or hydroxyapatite discs. Journal of Materials Science. Materials in Medicine, v. 7, p. 21-28, 1996.

DELIGIANNI, D. D.; KATSALA, N.; LADAS, S.; SOTIROPOULOU, D.; AMEDEE, J.;

MISSIRLIS, Y. F. Effect of surface roughness of the titanium alloy Ti-6Al-4V on human bone marrow cell response and on protein adsorption. Biomaterials, v. 22, n. 1, p. 1241-1251, 2001.

DEYNEKA-DUPRIEZ, N.; KOCDEMIR, B.; HERR, U.; FECHT, H. J.; WILKE, H. J.; CLAES, L. Interfacial shear strength of titanium implants in bone is significantly improved by surface topographies with high pit density and microroughness. Journal of Biomedical Materials Research. Part B, Applied Biomaterials, v. 82, n. 2, p. 305-312, 2007.

DORA, A.; LAW, F. C.; ALLEN, M. J.; RUSHTON, N. Neoplastic transformation of cells by soluble but not particulate forms of metals in orthopaedic implants. Biomaterials, $v$. 9, n.1, p. 751-759, 1998.

EISENBARTH, E.; VELTEN, D.; BREME, J. Biomimetic implant coatings, Biomolecular Engineering, v. 24, n. 1, p. 27-32, 2007.

FAGHIHI, S.; AZARI, F.; LI, H.; BATENI, M. R.; SZPUNAR, J. A.; VALI, H.; TABRIZIAN, M. The significance of crystallographic texture of titanium alloy substrates on pre-osteoblast responses, Biomaterials, v. 27, p. 3532-3539, 2006.

GIORDANO, C.; SANDRINI, E.; BUSINI, V.; CHIESA, R.; FUMAGALLI, G.; GIAVARESI, G.; FINI, M.; GIARDINO, R.; CIGADA, A. A new chemical etching process to improve endosseous implant osseointegration: in vitro evaluation on human osteoblast-like cells. The International Journal of Artificial Organs, v. 29, n. 8, p. 8772-8780, 2006.

GJURIC, M.; RUKAVINA, L. Evolution of stapedectomy prostheses over time. Advances in Oto-Rhino-Laryngology, v. 65, n.1, p. 174-178, 2007.

GORRIERI, O.; FINI, M.; KYRIAKIDOU, K.; ZIZZI, A.; MATTIOLI-BELMONTE, M.; CASTALDO, P.; DE CRISTOFARO, A.; NATALI, D.; PUGNALONI, A.; BIAGINI, G. In vitro evaluation of bio-functional performances of Ghimas titanium implants. The International Journal of Artificial Organs, v. 29, n. 10, p. 1012-1020, 2006.

GRAZIANO, A.; D'AQUINO, R.; CUSELLA-DE ANGELIS, M. G.; LAINO, G.; PIATTELLI, A.; PACIFICI, M.; DE ROSA, A.; PAPACCIO G. Concave Pit-Containing Scaffold Surfaces Improve Stem Cell-Derived Osteoblast Performance and Lead to Significant Bone Tissue Formation. PLoS ONE, v. 2, n. 6, p. 496-504, 2007. 
GROSSNER-SCHREIBER, B.; HERZOG, M.; JURGEN, H.; DUCK, A.; HANNIG, M.; GRIEPENTROG, M. Focal adhesion contact formation by fibroblasts cultured on surfacemodified dental implants: an in vitro study. Clinical Oral Implants Research, v. 17, n. 1, p. 736-745, 2006.

GUERRA NETO, C. L. B. Avaliação da osseointegração de implantes de titânio nitretados em plasma. 2005. 95 f. Tese (Doutorado em Ciência e Engenharia de Materiais) - Universidade Federal do Rio Grande do Norte, Natal, 2005.

HAÏDOPOULOS, M.; TURGEON, S.; SARRA-BOURNET, C.; LAROCHE, G.; MANTOVANI, D. Development of an optimized electrochemical process for subsequent coating of 316 stainless steel for stent applications. Journal of Materials Science. Materials in Medicine, v. 17, n. 7, p. 647-657, 2006.

HATANO, K.; INOUE, H.; KOJO, T.; MATSUNAGA, T.; TSUJISAWA, T.; UCHIYAMA, C.; UCHIDA, Y. Effect of surface roughness on proliferation and alkaline phosphatase expression of rat calvarial cells cultured on polystyrene. Bone, v. 25, p. 439-445, 1999.

HEALY, K. E.; DUCHEYNE, P. Hydration and preferential molecular adsorption on titanium in vitro. Biomaterials. v. 13, n.1, p. 553-561, 1992.

HOBO, S.; ISCHIDA, E.; GARCIA, L. T. Osseointegração e reabilitação oclusal. 1. ed. São Paulo: Santos Livraria Editora/Quintessence Editora Ltda, 1997. 345 p.

HSU, S. H.; LIU, B. S.; LIN, W. H.; CHIANG, H. C.; HUANG, S. C.; CHENG, S. S. Characterization and biocompatibility of a titanium dental implant with a laser irradiated and dual-acid etched surface. Bio-medical materials and engineering, v. 17, n. 1, p. 53-68, 2007.

HULTH, A. Fracture healing. A concept of competing healing factors. Acta orthopaedica Scandinavica, v. 51, n. 1, p. 5-8, 1980.

HUNTER, A.; ARCHER, C. W.; WALKER, P. S.; BLUNN, G. W. Attachment and proliferation of osteoblasts and fibroblasts on biomaterials for orthopaedic use. Biomaterials, v. 16, n. 4, p. 287-295, 1995.

IMWINKELRIED T. Mechanical properties of open-pore titanium foam. Journal of Biomedical Materials Research Part A, v. 81, n. 4, p. 964-970, 2007.

ISMAIL, F. S.; ROHANIZADEH, R.; ATWA, S.; MASON, R. S.; RUYS, A. J.; MARTIN, P. J.; BENDAVID. A.The influence of surface chemistry and topography on the contact guidance of MG63 osteoblast cells. Journal of materials science. Materials in medicine. v. 18, n. 5, p. 705-714, 2007. 
JAYARAMAN, M.; MEYER, U.; BÜHNER, M.; JOOS, U.; WIESMANN, H. Influence of titanium surfaces on attachment of osteoblast-like cells in vitro. Biomaterials, v. 25, n. 1, p. 625-631, 2004.

JOLY, J. C.; LIMA, A. F. M. Características da superfície e da fenda implante-intermediário em sistemas de dois e um estágios. Journal of applied oral science, v. 11, n. 2, p. 107113, 2003.

KASEMO, B. Biological surface science. Surface Science 500. p. 656-677, 2002.

KIESWETTER, K.; SCHWARTZ, Z.; HUMMERT, T. W.; COCHRAN, D. L.; SIMPSON, J.; DEAN, D. D.; BOYAN, B. D. Surface roughness modulates the local production of growth factors and cytokines by osteoblast-like MG-63 cells. Journal of biomedical materials research, v. 32, n.1, p. 55-63, 1996.

KIM, M. J.; KIM, C. W.; LIM, Y. J.; HEO, S. J. Microrough titanium surface affects biologic response in MG63 osteoblast-like cells. Journal of Biomedical Materials Research Part A, v. 79, n. 1, p. 1023-1032, 2006.

KLINGER, M. M.; RAHEMTULLA, F.; PRINCE, C. W.; LUCAS, L. C.; LEMONS, J. E. Proteoglycans at the bone-implant interface. Critical Reviews in Oral Biology \& Medicine, v. 9 , n. 1 , p. $449-463,1998$.

$\mathrm{KOHN}, \mathrm{D}$. H. Overview of factors important in implant design. Journal of oral implantology, v.18, n. 3, p. 204-219, 1992.

KOTHA, S. P.; LI, C.; MCGINN, P.; SCHMID, S. R.; MASON, J. J. Improved mechanical properties of acrylic bone cement with short titanium fiber reinforcement. Journal of materials science. Materials in medicine, v. 17, n. 12, p. 1403-1409, 2006.

KWOK, D. Y.; LEUNG, A.; LAM, C. N. C.; LI, A.; WU, R.; NEUMANN, A. W. Low-Rate Dynamic Contact Angles on Poly(methyl methacrylate) and the Determination of Solid Surface Tensions. Journal of Colloid and Interface Science, v. 206, n. 1, p. 44-51, 1998.

LANDES, C. A.; BALLON, A.; ROTH, C. Maxillary and mandibular osteosyntheses with PLGA and $P(L / D L) L A$ implants: a 5-year inpatient biocompatibility and degradation experience. Plastic and Reconstructive Surgery, v. 11, n. 7, p. 2347-260, 2006.

LAUTENSCHLAGER, E. P.; MONAGHAN, P. Titanium and titanium alloys as dental materials. International Dental Journal, v. 43, n. 1, p. 245-253, 1993.

LEE S. J.; CHOI, J. S.; PARK, K. S.; KHANG, G.; LEE, Y. M.; LEE, H. B. Response of MG63 osteoblast-like cells onto polycarbonate membrane surfaces with different micropore sizes. Biomaterials, v. 25, n. 1, p. 4699-4707, 2004. 
LENHARO, A.; COSSO, F. Carga imediata: em um único elemento dental. Um protocolo de duas horas. Implant News, v. 1, n. 2, p. 129-136, 2004.

LEVIN, D. E.; HOLLSTEIN, M.; CHRISTMAN, M. F.; SCHWIERS, E. A.; AMES, B. N. A new Salmonella tester strain (TA102) with A:T base pairs at the site of mutation detects oxidative mutagens. Proceedings of the National Academy of Sciences of the United States of America, v. 79, n. 1, p. 7445-7449, 1982.

LI, X. Q.; HOM, D. L.; BLACK, J.; STEVENSON, S. Relationship between metallic implants and cancer: a case-control study in a canine population. Veterinary and Comparative Orthopaedics and Traumatology, v. 6, n. 1, p. 70-74, 1993.

LIAO, H.; ANDERSSON, A. S.; SUTHERLAND, D.; PETRONIS, S.; KASEMO, B.; THOMSEN, P. Response of rat osteoblast-like cells to microstructured model surfaces in vitro. Biomaterials, v. 24, n. 1, p. 649-654, 2003.

LIM, Y. J.; OSHIDA, Y.; ANDRES, C. J.; BARCO, M. T. Surface characterizations of variously treated titanium materials. International Journal of Oral \& Maxillofacial Implants, v. 16, n. 1, p. 333-342, 2001.

LINCKS, J.; BOYAN, B. D.; BLANCHARD, C. R.; LOHMANN, C. H.; LIU, Y.; COCHRAN, D. L.; DEAN, D. D.; SCHWARTZ, Z. Response of MG63 osteoblast-like cells to titanium and titanium alloy is dependent on surface roughness and composition. Biomaterials, v. 19, n. 1, p. 2219-2232, 1998.

MALO, P.; NOBRE, M. D. E A.; PETERSSON, U.; WIGREN, S. A pilot study of complete edentulous rehabilitation with immediate function using a new implant design: case series. Clinical Implant Dentistry and Related Research, v. 8, n. 4, p. 223-232, 2006.

MARON, D. M.; AMES, B. N. Revised methods for the Salmonella mutagenicity test. Mutation Research, v. 113, n. 3-4, p. 173-215, 1983.

MARTIN, J. Y.; SCHWARTZ, Z.; HUMMERT, T. W.; SCHRAUB, D. M.; SIMPSON, J.; LANKFORD JR., J.; DEAN, D. D.; COCHRAN, D. L.; BOYAN, B. D. Effect of titanium surface roughness on proliferation, differentiation, and protein synthesis of human osteoblast-like cells (MG63). Journal of Biomedical Materials Research, v. 29, n. 3, p. 389-401, 1995.

MASUDA, T.; SALVI, G. E.; OFFENBACHER, S.; FELTON, D. A.; COOPER, L. F. Cell and matrix reactions at titanium implants in surgically prepared rat tibiae. International Journal of Oral and Maxillofacial Implants, v. 12, n. 4, p. 472-485, 1997.

MCCANN, J.; CHOI, E.; YAMASAKI, E.; AMES, B. N. Detection of carcinogens as mutagens in the Salmonella/microsome test - assay of 300 chemicals. Proceedings of the National Academy of Sciences of the United States of America, v. 72, n. 1, p. 5135-5139, 1975. 
MCGREGOR, D. B.; BAANA, R. A.; PARTENSKYA, C.; RICEA, J. M.; WILBOURNA, J. D. Evaluation of the carcinogenic risks to humans associated with surgical implants and other foreign bodies - a report of an IARC Monographs Programme Meeting. European Journal of Cancer, v. 36, n. 1, p. 307-313, 2000.

MEROLLI, A.; BOSETTI, M.; GIANNOTTA, L.; LLOYD, A. W.; DENYER, S. P.; RHYSWILLIAMS, W.; LOVE, W. G.; GABBI, C.; CACCHIOLI, A.; LEALI, P. T.; CANNAS, M.; SANTIN, M. In vivo assessment of the osteointegrative potential of phosphatidylserine-based coatings. Journal of Materials Science. Materials in medicine, v. 17, n. 9, p. 789-794, 2006.

MINTO, B. W.; BRANDÃO, C. V. S.; PEREIRA, G. J. C.; RANZANI, J. J. T. Prótese total da articulação coxofemoral em cães. Veterinária e Zootecnia, v. 13, n. 1, p. 7-17, 2006.

MORTELMANS, K.; ZEIGER, E. The Ames Salmonella/microsome mutagenicity assay. Mutation Research. v. 20, n. 1-2, p. 29-60, 2000.

MUHONEN, V.; HEIKKINEN, R.; DANILOV, A.; JAMSA, T.; TUUKKANEN, J. The effect of oxide thickness on osteoblast attachment and survival on NiTi alloy. Journal of Materials Science. Materials in Medicine, v. 18, n. 5, p. 959-967, 2007.

OLIVE, P. L.; BANATH, J. P. The comet assay: a method to measure DNA damage in individual cells. Nature Protocols, v. 1, n. 1, p. 23-29. 2006.

PALMA, F. D.; GUIGNANDON, A.; CHAMSON, A.; LAFAGE-PROUST, M.; LAROCHE N.; PEYROCHE, S.; VICO, L.; RATTNER, A. Modulation of the responses of human osteoblastlike cells to physiologic mechanical strains by biomaterial surfaces. Biomaterials, v. 26, n. 1, p. 4249-4257, 2005.

PARK, J. Y.; DAVIES, J. E. Red blood cell and platelet interactions with titanium implant surfaces. Clinical Oral Implants Research, v. 11, n. 6, p. 530-539, 2000.

PARSEGIAN, V. A. Molecular forces governing tight contact between cellular surfaces and substrates. Journal of Prosthetic Dentistry, v. 49, n. 1, p. 838-842, 1983.

PONSONNET, L.; REYBIER, K.; JAFFREZIC, N.; COMTE, V.; LAGNEAU, C.; LISSAC, M.; MARTELET, C. Relationship between surface properties (roughness, wettability) of titanium and titanium alloys and cell behaviour, Materials Science and Engineering: C, v. 23, n. 1, p. 551-560, 2001. 
RIDLEY, M. K.; HACKLEY, V. A.; MACHESKY, M. L. Characterization and surface-reactivity of nanocrystalline anatase in aqueous solutions. Langmuir. v. 22, n. 26, p. 10972-10982, 2006.

ROCHA, H. A. O.; BEZERRA, L. C. L. M.; ALBUQUERQUE, I. R. L.; COSTA, L. S.; GUERRA, C. M. P.; ABREU, L. D.; NADER, H. B.; LEITE, E. L. A xylogalactofucan from the brown seaweed Spatoglossum schröederi stimulates the synthesis of an antithrombotic heparan sulfate from endothelial cells. Planta Medica, v. 71, n.1, p. 379-381, 2005.

ROSA, A. L.; BELOTI, M. M. Rat bone marrow cells response to titanium and titanium alloy with different surface roughness. Clinical Oral Implants Research, v. 14, n. 1, p. 43-48, 2003.

ROSS, G. M.; MCMILLAN, T. J.; WILCOX, P.; COLLINS, A. R. The Single Cell Gel Electrophoresis Assay (comet assay): Technical Aspects and Applications. Report on the 5 th LH Gray Trust Workshop, Institute of Cancer Research. Mutation Research, v. 337, n. 1, p. 57-60, 1995.

RUSSEL, A. D. Bacterial resistance to disinfectants: present knowledge and future problems. Journal of Hospital Infection, v. 43, n. 1, p. 57-68, 1998.

RUSSELL, R. W.; YIMING, L. In vitro evaluation of biocompatibility of experimental titanium alloys for dental restorations. Journal of Prosthetic Dentistry, v. 80, n. 1, p. 495-500, 1998.

SÁ, J. C. Efeito das variáveis laboratoriais protéticas na adesão da porcelana com ligas de níquel-cromo. 2006. 89 f. Dissertação (Mestrado em Ciência e Engenharia de Materiais) - Universidade Federal do Rio Grande do Norte, Natal, 2006.

SALATA, L. A.; BURGOS, P. M.; RASMUSSON, L.; NOVAES, A. B.; PAPALEXIOU V.; DAHLIN, C.; SENNERBY, L. Osseointegration of oxidized and turned implants in circumferential bone defects with and without adjunctive therapies: an experimental study on BMP-2 and autogenous bone graft in the dog mandible. International Journal of Oral and Maxillofacial Surgery. v. 36, n. 1, p. 62-71, 2007.

SAVARINO, L.; FINI, M.; CIAPETTI, G.; CENNI, E.; GRANCHI, D.; BALDINI, N.; GRECO, M.; RIZZI, G.; GIARDINO, R.; GIUNTI, A. Biologic effects of surface roughness and fluorhydroxyapatite coating on osteointegration in external fixation systems: an in vivo experimental study. Journal of Biomedical Materials Research. Part A, v. 66, n. 3, p. 652661, 2003.

SAWASE, T.; HAI, K.; YOSHIDA, K.; BABA, K.; HATADA, R.; ATSUTA, M. Spectroscopic studies of three osseontegrated implants. Journal of Dentistry, v. 26, n. 2, p. 119-124, 1998.

SCHROEDER, A.; VAN DER ZYPEN, E.; STICH, H.; SUTTER, F. The reactions of bone, connective tissue and epithelium to endosteal implants with titanium sprayed surfaces.

Journal of Oral and Maxillofacial Surgery, v. 9, n. 1, p. 15-25, 1981. 
SCHWARTZ, Z.; MARTIN, J. Y.; DEAN, D. D.; SIMPSON, J.; COCHRAN, D. L.; BOYAN, B. D. Effect of titanium surface roughness on chondrocyte proliferation, matrix production, and differentiation depends on the state of cell maturation. Journal of Biomedical Materials Research, v. 30, n. 1, p. 145-155, 1996.

SHAH, A. K.; SINHA, R. K.; HICKOK, N. J.; TUAN, R. S. High-resolution morphometric analysis of human osteoblastic cell adhesion on clinically relevant orthopedic alloys, Bone, $\mathrm{v}$. 24, n. 1, p. 499-506, 1999.

SILVA, M. A. M.; MARTINELLI, A. E.; ALVES JR., C.; NASCIMENTO, R. M.; TÁVORA, M. P.; VILAR, C. D. Surface modification of Ti implants by plasma oxidation in hollow cathode discharge. Surface and Coatings Technology, v. 200, n. 8, p. 2618-2626, 2006.

SINGH, N. P.; MCCOY, M. T.; TICE, R. R.; SCHNEIDER, E. L. A simple technique for quantitation of low levels of DNA damage in individual cells. Experimental cell research, v. 175, n. 1, p. 184-191, 1988.

SOARES, A. L.; GOLDENBERG, S.; NOVO, N. F.; PAULA LIMA, C. A. Ligadura com algodão e com grampos de titânio em artérias de cães: estudo experimental em máquina simuladora de pressão. Acta Cirúrgica Brasileira, v. 16, n. 4, 2001. Disponível em: <http://www.scielo.br/acb>. Acesso em: 13 nov. 2007.

SOHN S. H.; JUN, H. K.; KIM, C. S.; KIM, K. N.; CHUNG, S. M.; SHIN, S. W.; RYU, J. J.; $\mathrm{KIM}, \mathrm{M}$. K. Biological responses in osteoblast-like cell line according to thin layer hydroxyapatite coatings on anodized titanium. Journal of Oral Rehabilitation, v. 33, n. 12, p. 898-911, 2006.

SPIEKERMANN, H.; JANSEN, V. K.; RICHTER, E. J. A. 10-year follow-up study of IMZ and TPS implants in the edentulous mandible using bar-retained overdentures. International Journal of Oral and Maxillofacial Implants, v. 10, n. 2, p. 231-243, 1995.

STANFORD, C. M.; KELLER, J. C.; SOLURSH, M. Bone cell expression on titanium surfaces is altered by sterilization treatments. Journal of Dental Research, v. 73, n. 1, p. 1061-1071, 1994.

THOMAS, K. A.; COOK, S. D. An evaluation of variables influencing implant fixation by direct bone apposition. Journal of Biomedical Materials Research, v. 19, n. 1, p. 875-901, 1985.

TWEDEN, K. S.; HARASAKI, H.; JONES, M.; BLEVITT, J. M.; CRAIG, W. S;

PIERSCHBACHER, M.; HELMUS, M. N. Accelerated healing of cardiovascular textiles promoted by an RGD peptide. Journal of Heart Valve Disease, v. 4, n. 1, p. 90-97, 1995.

VERCAIGNE, S.; WOLKE, J. G.; NAERT, I.; JANSEN, J. A. Histomorphometrical and mechanical evaluation of titanium plasma-spray-coated implants placed in the cortical bone of goats. Journal of Biomedical Materials Research, v. 41, n. 1, p. 41-48, 1998. 
VIEIRA, J. G. H. Considerações sobre os marcadores bioquímicos do metabolismo ósseo e sua utilidade prática. Arquivos Brasileiros de Endocrinologia e Metabologia, v. 43, n. 6, p. 415-422, 1999.

WALENCIAK, M. T.; ZIMMERMAN, M. C.; HARTEN, R. D.; RICCI, J. L.; STAMER, D. T. Biomechanical and histological analysis of an HA coated, arc deposited CPTi canine hip prosthesis. Journal of Biomedical Materials Research, v. 31, n. 4, p. 465474, 1996.

WEBER, H. P.; FIORELLINI, J. P. The biology and morphology of the implant-tissue interface. Scientific, v. 85, p. 61-64, 1992.

WEBER, H. P.; BUSER, D.; FIORELLINI, J. P.; WILLIAMS, R. C. Radiographic evaluation of crestal bone levels adjacent to nonsubmerged titanium implants. Clinical Oral Implants Research, v. 3, n. 4, p. 181-188, 1992.

WEISS, C. M. A comparative analysis of fibro-osteal and osteal inteal integration and other variables that affect long term bone maintenance around dental implants. International Journal of Oral Implantology : Implantologist, Abington, v. 13, n. 3, p. 467-487, 1987.

WENGEN, D. F. A new self-retaining titanium clip stapes prosthesis. Advances in OtoRhino-Laryngology. v. 65, n.1, p. 184-189, 2007.

WIELAND, M.; TEXTOR, M.; CHEHROUDI, B.; BRUNETTE, D. M. Synergistic interaction of topographic features in the production of bone-like nodules on Ti surfaces by rat osteoblasts. Biomaterials, v. 26, n. 1, p. 1119-1130, 2005.

XAVIER, S. P. Caracterização e avaliação da biocompatibilidade do titânio submetido a diferentes tratamentos de superfície. 2002. 116 f. Tese (Doutor em Odontologia) Universidade Estadual Paulista “Júlio de Mesquita Filho", Araçatuba, 2002.

ZARB, G. A.; ALBREKTSSON, T. Osseointegration: a requiem for the periodontal ligament? Journal Periodontal Restoration Dentistry, Chicago, v. 11, n. 1, p. 89-91, 1991.

ZHU, X.; CHEN, J.; SCHEIDELER, L.; REICHL, R.; GEIS-GERSTORFER, J. Effects of topography and composition of titanium surface oxides on osteoblast responses,

Biomaterials, v. 25, n. 1, p. 4087-4103, 2004.

ZREIQAT, H.; VALENZUELA, S. M.; NISSAN, B. B.; ROEST, R.; KNABE, C.; RADLANSKI, R. J.; RENZ, H.; EVANS, P. J. The effect of surface chemistry modification of titanium alloy on signalling pathways in human osteoblasts. Biomaterials, v. 26, n. 1, p. 7579-7586, 2005. 